From the 'Transactions of the Rotal Soctety of South Aprios,

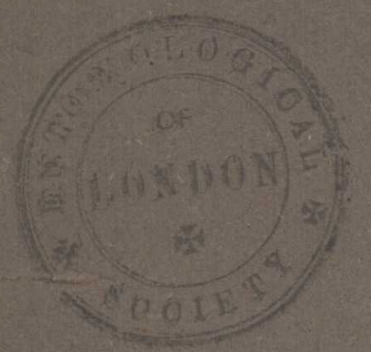
Vol. I., Part 1.

$$
\text { July, } 1909 .
$$

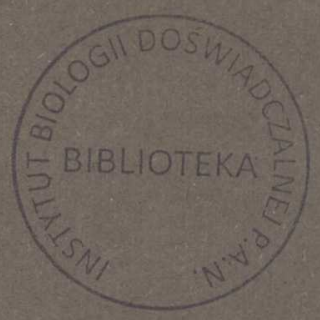

DESCRIPTIVE CATALOGUE OF THE COLEOPTERA OF SOUTH AFRICA.

BY

L. PÉRINGUEY, D.Sc., F.R.S.S.Af., F.E.S., F.L.S. 
(s)

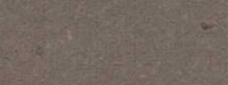

thin 


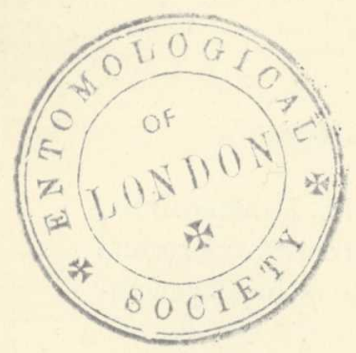

\title{
DESCRIPTIVE CATALOGUE OF THE COLEOPTERA OF SOUTH AFRICA.
}

\author{
By L. Péringuey, D.Sc., F.E.S., F.Z.S., \\ Director South African Museum. \\ Plates XXII.-XXIV.
}

\section{FAMILY MELOID丑.}

Mentum supported by a pedunculate gular process; ligula always projecting, more or less deeply sinuate, or sometimes incised; maxillæ with two corneous ciliate or penicillate lobes greatly variable in shape; palps seldom very long, the labial three-jointed, but with a distinct palpiger, the maxillary four-jointed; head much inclined, sometimes bent under, ending in a distinct neck not entirely received in the prothorax, the frontal part, as far as the antennæ which are inserted close to the eyes, is quadrate or transverse with the epistome and the labrum narrowed but parallel or nearly so laterally, or the whole head is triangular and even cuneiform; the suture of the epistome is at times wanting, eyes variable in size, strongly granulated, sub-reniform or hardly emarginate in front, but occasionally greatly developed underneath, and even sub-contiguous there (Zonitoschema). Number of antennal joints eleven, but occasionally reduced to seven in the Mylabrini, and inserted in front of the eyes in all the South African species; prothorax narrower than the elytra; prosternum without lateral suture, coxæ very large, the anterior contiguous with the cotyloid cavities very widely open behind, confluent, the intermediate contiguous behind, the posterior transverse ; mesosternum short, triangular; metasternum very short in the Meloince, long in the Cantharince; elytra without epipleuræ; abdomen six-jointed; legs long, tibial spurs always distinct, those of the hind tibiæ variable in shape, the outer one often thickened and hollowed outwardly; anterior and middle tarsi five-jointed, posterior four-jointed; claws usually divided into two parts, the lower much more slender than the upper, and occasionally filiform, the upper pectinate or simple.

This Family belongs to the group of Heteromera characterised by the presence of five joints in the anterior and. middle tarsi, and four in the hind tarsi. The head ends in a distinct neck as in the Families Anthicida, 
Pyrochroida, Rhipiphorida, \&c., which also belong to the Heteromera, but the Meloidac are easily recognised by their bi-partite claws. In some species of Cantharis, however, the lower part is partly or nearly completely fused with the upper.

A glance at Plate XXII., in which a figure of all the South African genera is given, shows how very different the facies of the Meloida is, and how very dissimilar also are the buccal organs of, let us say, Synhoria and Nemognatha, of Meloë and Zonitodema.

All the members of this Family have soft integuments, and they probably all emit through the leg-joints a substance called cantharidine, the chemical formula of which is $\mathrm{C}_{5} \mathrm{H}_{6} \mathrm{O}_{2}$, and which is used in medicine for raising blisters on the human skin, and other purposes.

The amount of cantharidine obtained from the South African Mylabridæ is said to exceed that of Cantharis vesicatoria, the species from which in Europe this produce is obtained.

According to Beauregard, two of the three or sometimes four pairs of glands connected with the genital organ of the male, and serving also as a seminal reservoir, are the seat of production of the active principle of the cantharidine. It is also found in the copulating sac, and in the ovaries of the female, but it is not restricted to these organs only, as it exists in the blood. The eggs have also an energetic blistering power, and we may conclude therefore that the larvæ even in their first stage have the same power as the eggs. This property, however, is stated to be less powerful in the Zonitini than in the Meloini and Cantharini; and is said to be absent in the Horiini. But the South African species Synhoria hottentota emits, like the species of Meloë, a pale yellow liquid through its leg-joints. As this liquid, which was erroneously thought to be blood, is found in the case of Meloë and other Cantharini to contain cantharidine, it is not unreasonable to suppose that it contains some also in the case of Synhoria.

In the adult stage most Meloida feed on foliage, grass or flowers. Mylabrini are, in South Africa, very destructive to the flowers of Leguminosæ. Mylabris oculata proves very injurious to crops of beans, peas, \&c., in the Eastern part of the Cape Colony, and also in the Transvaal. Of late it has taken to the blossoms of cultivated fruit trees. It is also at times not uncommon on the blossoms of our thorn, Acacia horrida. Mylabris hottentota is equally abundant in Natal and the Transvaal, to say nothing of the Orange River Colony, and any cultivated flower, roses especially, seems to be especially attractive to this species. I have never noticed any South African Mylabris feeding on leaves. Synhoria hottentota is met within or in the immediate vicinity of the dried logs or standing posts in which the carpenter bees of the genus Xylocopa have burrowed their nests. Meloë, like its congeners elsewhere, drags its tumid body on the ground, and feeds on the foliage of low plants. Cyaneolytta 
crawls about the ground, or is to be seen on the young grass, which it devours with great voracity. Rev. J. O'Neil, of Plumtree, Southern Rhodesia, informs me that a species (C. signifrons) "was particularly abundant a week after the first summer rains. He saw 3 or 400 under a single bush." Of the three species of Cantharis with glabrous elytra, one, C. nitidula, is usually found on the iridaceous plant Bobartia spathea; another one, C. lucida, in nearly any flower; Iselma again is met with in numbers in the flowers of the Gazania and Dimorphotheca, belonging to the Compositæ. When fearing attack or capture all sham death, drawing their head against the prosternum, tucking the legs under the body, and emitting at the same time through the leg-joints the pale yellow fluid already mentioned. It has been proved that this fluid is a means of protection against lizards, and probably also against small mammals or birds. The very conspicuous livery of the Mylabrini acts probably as a "danger signal" for their would-be devourers. Be it as it may, they supplement it by a very fetid, almost nauseous smell when seized.

In the adult stage, most of the species the life history of which is known fully or partly, make a hole in the ground in which they lay the eggs. Meloë, however, do not deposit them in one spot only, or at one given time. They are extremely prolific insects, but the number of eggs varies, however, according to the size. Newport found 4,218 eggs in the ovaries of a female. Goedart counted 3,000 in the first laying, and 900 in the second. Cantharis deposit their eggs in two masses containing from 150 to several hundreds. Mylabris are not so prolific, the number of the eggs varying from 25 to 40 . Sitaris do not lay the eggs in a hole, but deposit them at the entrance of the burrows or galleries of solitary bees. Fabre evaluates the number of eggs laid in that position by one female at 2,600 eggs. There is reason, however, to believe that usually the number is less than that, although still very considerable. In their early stages the Meloida are parasites. They either feed on the honey made by Hymenoptera, on the orthopterous insects collected as food-stores by fossorial wasps: on the eggs of locusts, the egg-pod of which they enter, or here on the larvæ of ground-loving Psychid moths, into the sac of which they have penetrated. The eggs are laid in all likelihood near the nests of the bees or wasps, or the place of oviposition of the locusts.

But instead of passing through the three usual stages, or instars, of larva, pupa, imago, they undergo from six to eight transformations, changing altogether their first form, losing their legs, turning to bladderlike creatures which at a later stage become again active, returning in the fourth stage to the shape of the second, \&c. These unusual changes are called Hypermetamorphoses.

The young larva is called Triungulin. It is always a tiny, very active 
creature with a broad head and strong mandibles, the three pairs of long legs terminating each in three tarsal claws.

In the case of Meloë and certain kinds of Cantharis feeding on honey and possibly bee-bread, the Triungulin or primary larva climbs the stem of plants and awaits there the arrival of bees or other flower-frequenting insects, hooks itself on their hairs, and, if its carrier happens to be a bee, it is conveyed into the nest. It penetrates a cell during the oviposition, or possibly after the storage of the cell is already completed, and devours first the egg of the rightful owner and turns into the second larva which assumes quite a different aspect, having on that account the name caraboid-stage given it; it is soft, and eventually assumes the third stage, that of pseudo-pupa, but still within the second larval skin; it is then mostly motionless; in the next stage this pseudo-pupa turns to a larval form closely resembling that of the second instar, but also without shedding its skin, being thus wrapped into two; in this envelope it changes to the true pupa, and lastly appears as the perfect insect. It has then undergone six transformations.

According to Riley, these post-embryonic developments are a little more complicated in the cases of some North American species of Cantharis (Epicauta), the young of which feed on locust eggs. The active triungulin does not cling to the hairs of bees, but sets about finding the egg-pods of locusts. Should two or more triungulins penetrate the same egg-pod, they fight until only one is left. The instars are then as follows (ap. Sharp) : (1) Triungulin larva-moult; (2) Caraboid larva-moult; (3) Scarabæoid larva-moult; (4) Scarabæoid larva ultimate stage-moult; (5) Coarctate larva-moult; (6) Scolytoid larva-moult; (7) pupa-moult; (8) perfect insect. It may, however, be added that Riley's three and four instars do not differ much from the sixth.

Sitaris deposit their eggs at the mouth of the galleries of burrowing Hymenoptera. In one species observed by Fabre the triungulins pass the winter there, motionless, under the shell of the egg, before clinging to the hairs of the passing Anthophora that are to introduce them into the galleries of the nest. But in other species the triungulin fastens itself at once to the Colletes, Halictus, or Andrena bees entering the nests.

The different stages in this hypermetamorphosis vary in duration; the habits of the larvæ of different species and genera are also presumably not the same.* Certain species are certainly produced during a season, others are not. It seems from all observations that it is in the pseudo-pupal state that the stage is the longest, lasting occasionally over a year. In Cantharis vesicatoria Beauregard finds that the triungulin, unlike in that respect that of Meloë and Sitaris, does not devour the hymenopterous egg laid in the cell, but feeds on the honey at once, and that the second larva

* See p. 290. 
instead of remaining enclosed in the cell, the contents of which it has emptied, buries itself into the ground to a depth of 3 feet, and, after a third moulting, changes there into a pseudo-pupa. This third moulting corresponds thus to Riley's first Scarabæoid stage of the congeneric Cantharis (Epicauta) of North America, which, however, in the second stage forms only a small cavity near the egg-pod from which it has derived its nourishment. The young of Cerocoma, a genus not represented in Africa, attack the stores of provision brought together by a burrowing wasp of the genus Tachytes, and consisting of paralysed young Mantis intended by the wasp for its young.

Nothing is known of the habits of the Mylabrini beyond the fact that the triungulins are considerably larger than those of Meloë and Cantharis, and that the number of eggs is very much smaller.

It must not, however, be imagined that those triungulins which ascend plants to encounter the carrier that will introduce them into its abode show any discrimination as to the identity of their conveyance, because they do not, and I have seen some holding on to the rare hairs of dipterous flies, and also on flower-frequenting Coleoptera. Their chance of finding a "home" is thus made greatly uncertain, and the number of successful ones is probably very small. But the great fertility of some of the species counterbalances this great disadvantage.

In South Africa examples of Meloë, the most prolific of the Meloida, are undoubtedly rare. On the other hand, Cantharini, Mylabrini, Zonitini are very numerous in kinds and extremely abundant in individuals.

One genus, Iselma, is purely endemic; Zonitomorpha may prove also to be so.

The Family is divided into two Sub-Families, distinguished as follows :-

Metasternum very short, intermediate coxæ covering part of the posterior ones; side pieces of meso- and metathorax covered by the epipleuræ of the elytra; no scutellum, or scutellum extremely reduced; no wings ..

Metasternum long, intermediate coxæ distant from the posterior; side pieces of meso- and metathorax plainly visible; scutellum well defined;

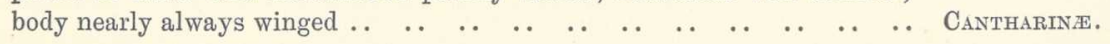

\section{Sub-FAMILY MELOÏN无.}

This Sub-Family is represented in Africa by the genus Meloë only, which numbers in South Africa five species, of a dark blue or blue-black colour, making their appearance in the spring or after the first summer rains, and met with in dry or sandy spots where the nests of Hymenoptera abound. They do not proceed fast, the females especially, owing to the extreme development of the abdomen the segments of which are enor- 
mously distended. The sexual differences consist in the males being usually smaller than the females, and in the apical abdominal segment of the former being more or less deeply incised, while it is entire in the latter; but in certain species the intermediate antennal joints are nodose or greatly enlarged in the male.

\section{GEN. MELOË, Linn., \\ Syst. Nat., 10th ed., 1758, p. 419.}

Mentum (pl. xxii., fig. 3) transverse, sub-angular laterally and sinuate near the margin ; ligula also transverse, arcuate, ciliate along the anterior margin, labial palps robust, thick, the ultimate triangularly dilated, almost truncate at apex; maxillæ (pl. xxii., fig. $3 a$ ) also robust, both the inner and upper lobes dilated and densely ciliate, pubescent at apex; maxillary palps moderately long and of the same shape as the labial ; labrum transverse, either emarginate at apex or not; mandibles robust, more or less hidden by the labrum; head longer than broad, with the transverse epistome greatly narrowed, eyes only moderately large; antennæ variable in shape and length, the second basal joint always much smaller than the third, the last one longer than any of the preceding ones, sub-arcuate outwardly, straight inwardly and sharp at tip; prothorax of variable shape (pl. xxii., figs. 3,4 ) ; scutellum atrophied ; elytra very short, strongly divaricating from or near the scutellary region, much shorter than the abdomen: wings absent; legs moderately long or long, tarsi as long as the tibiæ or longer; outer spur of hind tibiæ thick, obliquely truncate outwardly, or sub-lanceolate and exeavated, inner spur slender and sharp; upper part of claw not pectinate, lower very slender.

The abortion of the wings, the great divarication of the elytra, and the extremely large abdomen impart to the insects belonging to this genus a facies of their own. When seized they exude through the joints of the legs, especially the knees, a yellow fluid, much in the same manner as in the genus Horia. It is this peculiarity which has gained for them the popular name of " oil beetles."

Four species are recorded from Central Africa, but none from Senegambia, where, however, the genus is probably represented.

\section{Key to the Species.}

$\mathrm{A}^{2}$. Antennæ barely reaching the posterior angle of the prothorax.

$\mathrm{B}^{2}$. Prothorax with a median longitudinal groove and no transverse impression along the base.

$a^{2}$. Body black.

Prothorax very roughly scrobiculate, as broad as long and sharply angular laterally in front; elytra finely plicate-wavy $\begin{array}{lllllllllllll}\text { longitudinally } & . & \ldots & \ldots & \ldots & \ldots & \ldots & \ldots & \ldots & . & \ldots & . & \text { angulatus. }\end{array}$ 


\section{$a^{\mathrm{x}}$. Body dark blue.}

Prothorax foveate punctate, longer than broad, angular laterally in the male, moderately so in the female; elytra with longitudinal highly raised wavy lines; upper side of abdomen longi$\begin{array}{lllllllllll}\text { tudinally striolate } & . . & . . & . . & . . & . . & \ldots & . . & . . & . . & . .\end{array}$ meridianus.

Prothorax scrobiculate, longer than broad, well rounded laterally in front; elytra with very highly raised and very wavy longitudinal folds; abdomen with strong, rugose wavy

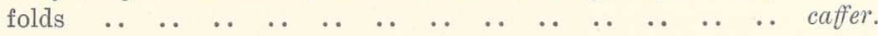

$A^{x}$. Antennæ reaching beyond the humeral part of the elytra.

$B^{\mathrm{x}}$. Prothorax not grooved longitudinally, and with a transverse impression along the base.

Sixth and seventh antennal joint very broadly dilated, and hollowed underneath in the male.

Anterior part of prothorax not angular laterally in front.

Body dark blue or blue-black; elytra with very closely set, little raised, wavy folds.

Prothorax plainly ampliate, rounded laterally in front, and covered with deep, elosely set, round punctures; intervals somewhat roughened ..

Prothorax only slightly ampliate, rounded in front, and with round, not closely set punctures, intervals quite smooth $\quad . . \quad \ldots \quad . \quad . \quad . \quad$ rhodesianus.

\section{Melö̈ angulatus, Leach, Plate XXII., figs. $3,3 a, 3 b$.}

Trans. Lin. Soc., xi., 1815, p. 247 ; Brandt and Erikss., Mon., p. 132, pl. 8, fig. 5 .

Black, somewhat opaque; head scrobiculate foveolate, the foveæ divided by a sharp, raised wall, the hind part is slightly wider than the anterior part of the prothorax and slightly canaliculate on the vertex only, the groove disappearing as it reaches the middle of the frontal part; antennæ black, short, not reaching beyond half the length of the prothorax; prothorax somewhat short, as broad as long at its widest part, straight laterally, sub-truncate in front with the lateral angles very sharp, and the posterior slightly blunted, covered with broad scrobiculate foveæ with more uneven walls than those on the head, deeply and somewhat broadly grooved longitudinally in the centre, and with a supra-marginal longitudinal depression on each side; elytra divaricating at about onethird of the length and covered with closely set, little raised, slightly wavy folds; abdominal segments longitudinally shagreened; legs pubescent, claws piceous. 
Length (excl. of abdomen) 12-16 mm.; width 7-12 mm.

Hab. Cape Colony (Cape Town, Malmesbury, Stellenbosch, Paarl, Worcester, Namaqualand, Knysna).

Melö̈ meridianus, Pér.,

Trans. S. Afric. Phil. Soc., iv., 1892, p. 12.

Very dark blue, moderately shiny; head broader than the anterior part of the prothorax and covered with round, deep, sub-foveolate punctures the intervals of which are somewhat broad and smooth, the posterior part of the vertex is only slightly sinuate in the centre but not canaliculate; prothorax straight laterally but narrower at the base than in the anterior part, the hind angles are distinct although not acuminate, the anterior ones are also plain, although slightly blunt, but from there the anterior part is strongly narrowed obliquely, the median part is very broadly grooved from apex to base, there are no traces of a supra-marginal lateral longitudinal depression, and the surface is covered with deep, foveate punctures separated by a narrow, somewhat raised smooth wall ; elytra divaricating at about one half of the length and covered with highly raised, very wavy longitudinal folds separated from each other by an interval wider than the fold itself; abdomen longitudinally shagreened; legs densely but briefly pubescent.

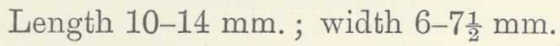

Hab. Ovampoland (Omaramba); Southern Rhodesia (Plumtree); Transvaal (Waterberg, Zoutpansberg).

\section{Melö̈ Caffer, Péring.,}

Trans. S. Afric. Phil. Soc., iii., 1886, p. 123.

Dark blue, somewhat purple on the head and prothorax, moderately shiny; head slightly wider than the prothorax at its widest part, deeply and irregularly scrobiculate punctate, and having in the centre a deep median groove reaching from the vertex to the central part and continued thence to the transverse groove; prothorax sub-quadrate, slightly narrower at base than at apex, the posterior angles are slightly rounded, the anterior lateral part is slightly ampliate with the outer angles rounded, the upper side is more deeply scrobiculate than the head, there is a very deep and broad median longitudinal groove and a parallel depression on each side of the disk; elytra divaricating at about one half of the length, and covered with longitudinal highly raised and greatly wavy carinate folds which are twice as narrow as the intervals; abdominal segments very closely shagreened; legs very briefly pubescent.

Length $10 \frac{1}{2}-15 \mathrm{~mm}$; width $4-7 \mathrm{~mm}$.

Hab. Natal (Durban, Maritzburg); Transvaal (Lydenburg). 


\section{Meloë hottentotus, Péring., Plate XXII., fig. 4.}

Trans. S. Afric. Phil. Soc., iii., 1886, p. 123.

Dark blue, moderately shiny; head broader than the prothorax and covered with deep sub-foveolate round punctures closely set and separated by a nearly smooth interval, there is no median groove in the vertex or above the epistome; antennæ long, reaching to about the median part of the elytra, the fifth, sixth, and seventh joints are broader than the others in both sexes, being very broadly dilated and hollowed underneath in the male; prothorax longer than broad, ampliate rounded laterally in front and having thus no distinct neck, not grooved longitudinally in the centre but having there an ill-defined smooth line covered with deep foveate punctures set close to each other especially in the anterior part, and transversely impressed along the base for about two-thirds of the width; posterior angles distinct ; elytra divaricating past the median part, covered with sub-contiguous, raised wavy folds ; abdomen shagreened.

Length 12-16 mm.; width 4-7 $\mathrm{mm}$.

Hab. Cape Colony (Port Elizabeth); Natal (Durban, Maritzburg); Transvaal (Lydenburg).

\section{Sub-FAMily CANTHARIN五.}

$A^{2}$. Head transverse or quadrate; anterior part parallel, not cuneiform.

$\mathrm{B}^{2}$. Mandibles prolonged, very sharp.

Labrum extremely short, mandibles very robust, unidentate inwardly; palps long.

Upper part of the claws pectinate.

Elytra covering the abdomen, not dehiscent along the suture .. .. Horirns.

$B^{x}$. Mandibles not prolonged.

$\mathrm{C}^{2}$. Antennæ arcuate, last joint thickened externally.

$\mathrm{D}^{2}$. Upper part of the claws not pectinate.

Number of joints varying from eleven to seven; elytra not

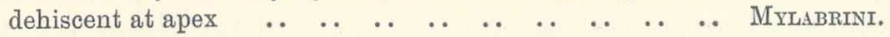

$\mathrm{C}^{\mathrm{x}}$. Antennæ straight, last joint not thickened externally.

Number of joints eleven; elytra covering the abdomen but occasionally broadly rounded at the apex of the suture .. CANTHarini.

$D^{x}$. Upper part of the claws pectinate.

Number of joints eleven; elytra not covering completely the abdomen, strongly sinuate laterally and dehiscent along

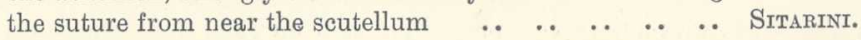

$\mathrm{A}^{\mathrm{T}}$. Head triangular, anterior part cuneiform.

Maxillary lobes slender, elongate or greatly prolonged and even setaceous Zonitins. 


$$
\text { GeN. SYNHORIA, Kolb., }
$$

Kaf. Deutsch.-Ost. Afrikas, 1897, p. 256.

Arrow., Ann. and Mag. Nat. Hist., 8 ser., vol. ii., 1908, p. 204.

Mentum extremely narrow, transverse, palpigers broad, strongly developed, ligula nearly transverse, very short, briefly pubescent along the margin, labial palps very long, the intermediate one longer than the first and third taken together; maxillæ very short, the lower lobe supported by a broad and short palpiger is hardly distinguishable, the upper lobe is slender, fasciculate at the tip, slightly so inwardly, and projects very little beyond the basal joint of the maxillary palps the joints of which with the exception of the basal are very long, the apical one being somewhat fusiform and slightly truncate at tip; mandibles very robust, long ( $q$ ) or very long $(\delta)$ arcuate and each provided with a sharp, malar tooth; labrum rudimentary; head declivous, transverse, very broad or broad according to sexes, epistome very narrow, eyes large, sub-reniform, antennæ short, basal joint massive, knobby at tip, second smaller than the first but also knobby and more robust than the following ones, the first five of which are sub-turbinate, the others are slightly compressed, longer than broad, the last one being longer than the penultimate; prothorax twice as broad as long; scutellum very broad, acuminate at apex, rounded there; elytra elongate, as broad as the prothorax at the base, little convex, singly rounded at apex; legs compressed, moderately slender, tibiæ with very small spurs, tarsi long, hispidous underneath, claws robust, the upper side also robust, pectinate, but slender and simple at the hooked part, the lower filiform, not spatulate at tip.

The $\delta$ differs from the $q$ in the very great development of the head and mandibles, the latter being longer than the head, which is broader than the prothorax, and has on each side of the base a conspicuous calluslike process, and underneath close to the point of insertion of the antennæ a vertical, conspicuous tooth; the ligula has on each side a short, acute membranous lobe wanting in the $q$, in which sex the head is narrower than the prothorax, the labrum is more distinct, the eyes are more developed underneath; the mandibles are also projecting but do not compare in size with those of the $\pi$, and the elytra are nearly parallel laterally, whereas they are strongly sinuate past the middle in the $\delta$.

Found in the nests of several species of Carpenter Bees belonging to the genus Xylocopa. When captured these insects exude at the knees a considerable quantity of yellowish fluid.

\section{Key to the Species.}

$\mathrm{A}^{2}$. Prothorax with a deep discoidal impression on each side; punctures on the upper side deep, very closely set; posterior angles of the head bulging out in the male..

hottentota. 
$\mathrm{A}^{\mathrm{x}}$. Prothorax without any discoidal impression on each side; punctures on the upper side very fine and very closely set; posterior angles of the

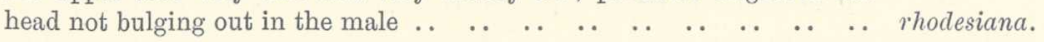

Synhoria hottentota, Péring., Plate XXII., fig. 2, $2 a, 2 b$.

Trans. S. Afric. Phil. Soc., iv., 1888, p. 134.

Bright red, palpi, antennæ, tibiæ and tarsi black, apical part of the mandibles deeply infuscate. In the male the elytra have occasionally on each side a small juxta-scutellary and a sub-humeral black spot, two post-median spots or dots between the second costa and the outer margin, and a similar one above the apex in the first interval; these black spots are somewhat asymmetrical. Head deeply punctate and very briefly pubescent, the punctures are more closely set in the female than in the male, in the latter the basal part of the sides project strongly; prothorax deeply and closely punctate, and briefly pubescent, the pubescence, however, being longer laterally in the female than in the male, it is longer than broad in both sexes, in the male it is narrowly grooved in the centre from the base to a short distance from the apex and has on each side a deep impression, whereas in the female it is grooved from the base to the apex and is much less conspicuously impressed on each side of the disk; scutellum punctulate; elytra deeply punctulate, the punctures are almost contiguous, and the intervals slightly raised, thus imparting to the elytra a faintly shagreened appearance, the two dorsal costæ are very distinct, and the pubescence is very short, but very dense ; under side and legs closely punctate, pubescent.

Length (excl. of mandibles) 21-32 mm.; width 6-11 mm.

Hab. Cape Colony (Cape Town, Worcester, Knysna); Natal (Durban); Damaraland (Goagas); Ovampoland.

Two examples from Damara are a little darker in colour than the Cape and Natal examples the males of which have also a longer pubescence on the prothorax.

\section{Synhoria Rhodesiana, n. sp.}

Male: Brick red with the apex of the mandibles, the antennæ, and the basal part of the femora black; head and prothorax not distinctly pubescent, the pubescence on the elytra is extremely fine, and the latter has two rudimentary fuscous, asymmetrical spot-like patches on each side near the base; head straight laterally behind the eyes, the longitudinal central groove is visible in the centre of the frontal part only, the punctuation is very fine and is to be seen only on the sides; prothorax very transverse, plainly pubescent laterally, covered with somewhat remote fine punctures 
on the sides, slightly grooved longitudinally in the centre, and having no discoidal impression on each side of the groove; scutellum punctulate; elytra very closely aciculate, the two dorsal costæ are quite distinct; under side finely aciculate, very briefly pubescent.

Length (excl. of mandibles) $21 \mathrm{~mm}$.; width $8 \mathrm{~mm}$.

Hab. Southern Rhodesia (Umtali).

\section{TRIBE MYLABRINI.}

Mentum ampliate rounded laterally, longer or as long as broad, attenuate in front; ligula elongated, much narrower than the mentum, corneous or membranaceous, dilated and deeply sinuated and densely pubescent in front; palps somewhat short; maxillæ robust, inner lobe (maxilla) with a broad, thick bunch of fulvous hairs, upper lobe (galea) moderately slender, somewhat compressed and as densely penicillate inwardly as the inner; labial palps short, ultimate one truncate; maxillary palps moderately long, robust, ultimate one cylindrical and truncate at tip, both palps hairy; mandibles sharply arcuate at tip, provided inwardly with a broad corneous membrane having a briefly pubescent edge, right mandible with a very distinct inner tooth at a short distance from the point; head slightly longer than broad, provided with large, barely incised eyes, epistome usually transverse, labrum long, sinuate in front; antennæ robust, short, arcuate, the number of their joints varying from eleven to seven, first joint short, more or less clavate, second very small, third longer or as long as the fourth, the intermediate transverse, more dilated inwardly than outwardly, last one always longer and thicker than the others, ovate or swollen outwardly and more or less sharply acuminate at tip; prothorax as long as broad, strongly attenuate in the anterior part, sub-parallel in the posterior, truncate at base, and only half as wide as the elytra; scutellum short, semicircular; elytra elongated, sub-cylindrical but slightly ampliated in the posterior part, singly rounded at apex, longer than the six-segmented abdomen, and with the shoulders rounded, the wings are present; intermediate coxæ situated far from the posterior, but set close to the anterior, both being longitudinal, while the posterior are transverse; legs very long; tarsi very long, slightly compressed, claws long, cleft into two, the upper part slightly more robust than the lower, and both simple.

The body of all the species is very hairy; the elytra, however, are less pubescent than the rest of the body. They are black or brown relieved by yellow or red patches and transverse bands, the punctuation of which, and also the colour of their pubescence, differs slightly from that of the background. These patches or bands invade occasionally the greater part of the surface, making it difficult to ascertain which is the right 
colour. I have assumed in my descriptions that the background is black or dark brown.

The extreme variation in the disposition of these yellow or red markings makes the study of the species of this genus extremely difficult. Moreover, examples differ considerably in size, and the sculpture varies accordingly.

In order to facilitate the identification I have named and figured the varietal forms. There is little doubt that the habitat of several of these varieties might prove to be restricted to certain localities, in which case they will have to rank as species.

It is singular that in spite of the great range in the South African area of certain species or their varieties, such as Mylabris oculata, M. alterna, Decatoma lunata, Ceroctis phalerata, \&c., only three, i.e., Mylabris holosericea, $M$. dentata, and Coryna argentata, originally described from Senegambia, are occasional intruders.

The difference in the number of antennal joints has been made use of for dividing this tribe into sections, so as to facilitate identification. This difference is caused by the fusion of two or more of the penultimate joints with the ultimate one; these articles are thus merged into a thick ovoid or club-shaped one, in which the suture is, however, occasionally visible.

A5. Antennæ 11-jointed.

Key to the Genera.

$B^{2}$. Prothorax strongly attenuate in front; elytra convex.

Inner part of intermediate antennal joints not strongly serrate .. Mylabris.

Inner part of intermediate antennal joints very strongly serrate.. Ceroctis.

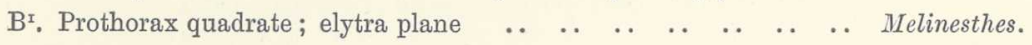

A4. Antennæ 10 -jointed $\ldots{ }^{4}$..

A3. Antennæ 9-jointed..

$\mathrm{A}^{2}$. Antennæ 8-jointed..

$\mathrm{A}^{\mathrm{I}}$. Antennæ 7-jointed..

$$
\begin{gathered}
\text { Gen. MYLABRIS, Fabr., } \\
\text { Plate XXII., fig. } 1 . \\
\text { Syst. Entom., } 1775 \text {, p. } 261 \text {, No. } 78 .
\end{gathered}
$$

Antennæ 11-jointed, not strongly serrate inwardly.

Key to the Species.

$A^{2}$. Elytra with two transverse yellow or yellow and brownish red bands.

B. Head and prothorax clothed with a dense, black, non-silky pubescence.

$C^{2}$. Third basal antennal joint longer than the fourth.

$D^{2}$. Basal part of elytra not completely invaded by the dorsal and lateral yellow patches. 
$a^{5}$. Antennæ yellow with the two basal joints black or fuscous.

Basal part of elytra with a large jellow patch, and a very distinct lateral one; the two transverse bands broad, of nearly equal width throughout, hind border of the hind band very narrowly edged with rufous brown (pl. xxiii., fig. 1) ..

Basal part of elytra with a small dorsal spot and a lateral dot, hind border of the second posterior band very distinctly edged with rufous brown (pl. xxiii., $\begin{array}{lllllllllll}\text { fig. 2) } & \text {.. } & \text {. } & \text {.. } & \text {.. } & \text {.. } & \text {.. } & \text {. } & \text {.. } & \text {.. } & \text {.. }\end{array}$

Basal part of elytra with a small dorsal spot, and a minute lateral dot, posterior band narrowed from the median part to the outer margin, being there only half the width of the inner dorsal part, hind border broadly edged with rufous brown (pl. xxiii.,

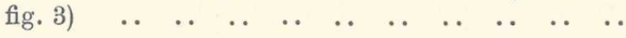

Basal part of elytra with two dots, anterior band covering almost half the length and connected laterally with the somewhat narrow posterior one from the outer margin to about the median part, the background along the suture being triangular and rufous brown, hind border of the posterior band very broadly edged with rufous brown (pl. xxiii., fig. 4) oculata.

var. kakamas.

Basal part of elytra with a dorsal, moderately sized spot, and a lateral dot, anterior band equal in width to about one-fourth of the surface and not sinuate, post-median part with a broad rufescent band slightly wider than the anterior, and along the upper edge of which runs a narrow yellow band reaching from the suture to about the middle, and a small yellow spot close to the outer margin (pl. xxiii., fig. 5) ..

Basal part of elytra with a broad dorsal and lateral yellow patch, the anterior band is very broad and yellow, the posterior one which is only half the width of the anterior is reddish, ovate towards the lateral margin, and somewhat narrowed towards the suture (pl. xxiii., fig. 6) $\quad$..

Basal part of elytra with a moderately wide dorsal patch, and without lateral dot, anterior band yellow, narrower above the outer margin than towards the suture, posterior band, narrower than the anterior, reddish with its fore edge more or less broadly yellow towards the inner part (pl. xxiii., fig. 7) ..

Basal part of elytra with a lateral yellow dot, no dorsal one, anterior band yellow, quite transverse, equal in width to two-fifths of the whole length, and almost contiguous with a very broad rufous brown band of nearly equal width (pl. xxiii., fig. 8)

var. vulgaris.

var. transitoria.

var. vicaria.

var. tricolor.

var. amatonga.

hottentota. 
Basal part of elytra with a narrow, transverse or sub-ovate very small dorsal yellow patch and a lateral dot, anterior band narrow, slightly sinuate, and a little narrower near the outer margin than at the suture, posterior band rufescent, nearly twice as wide as the anterior, not sinuate (pl. xxiii., fig. 9) myops.

Basal part without dorsal or lateral pateh or spot, two narrow yellow bands the posterior of which is slightly sinuose, and either of equal width, or slightly narrowed towards the outer margin (pl. xxiii., fig. 10)

Basal part with an ovate dorsal yellow patch and a lateral spot, anterior band yellow, narrow, strangulated in the centre, posterior also yellow, and somewhat broadly interrupted in the centre (pl. xxiii., $\begin{array}{lllllllllll}\text { fig. 12) } & \ldots & \ldots & \ldots & \ldots & . & \ldots & \ldots & \ldots & \ldots & \text {.. }\end{array}$ hybrida.

Basal part without dorsal or lateral patch or spot, anterior yellow band narrow, lower edge plainly bi-sinuate, posterior band orange yellow, somewhat slanting, broader than the anterior, widest in the centre, and with both edges plainly bi-sinuate

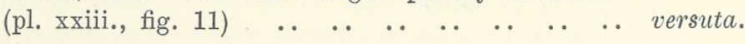

$a^{4}$. Antennæ yellow with the three basal joints black.

Basal part of elytra with no lateral spot, and having a transversely ovate yellow dorsal patch, coalescing with the anterior yellow band which is broad, but narrowed from the margin to the suture, posterior one narrower than the anterior and considerably reduced in width from the middle to the outer margin, plainly bi-sinuate on each side, and separated from the anterior band by a very narrow space (pl. xxiii., fig. 13) $\quad$.

Same as the type but with the two dorsal bands coalescing along the suture (pl. xxiii., fig. 14).

Basal dorsal spots separated from the anterior band, posterior band separated along the margin from the anterior (pl. xxiii., fig. 15).

$a^{3}$. Antennæ yellow with the four basal joints black.

No dorsal or lateral patch or spot, anterior band deep yellow and ascending greatly towards the base, very broad, lower edge slightly bi-sinuate, posterior band less broad than the anterior, anterior margin incised and narrowed from the middle to the outer margin (pl. xxiii., fig. 16)

$a^{2}$. Antennæ yellow with the five basal joints black.

The five apical joints bright yellow. 
Basal part of elytra with a transversely ovate patch, no lateral spot, anterior band yellow, narrow, broadening slightly along the margin, posterior band either not broader than the anterior and sinuose, or broadly dilated from the centre to the outer margin (pl. xxiii., figs. 17, 18) $\quad$. $\quad . . \quad \ldots \quad$ plagiata.

The same but with the posterior band suffused with orange, and three times as broad as the anterior; prothorax not coarsely punctate (pl. xxiii., fig. 19)..

hamacta.

The same as hamacta, but without any traces of basal dorsal patch; prothorax very coarsely punc-

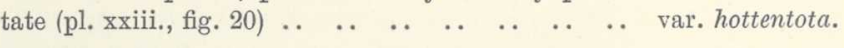

$a^{I}$. The five apical joints infuscate, almost black.

Basal part of elytra with an ovate rounded orangeyellow patch, no lateral one, bands orange yellow, anterior one narrow, strangulated in the centre, posterior one broader, slanting from the median dorsal part to the outer margin (pl. xxiii., fig. 21) ..

lavatera.

Basal part of elytra with an ovate rounded orange patch, no lateral one, bands of the same colour, anterior one interrupted in the centre, posterior strongly slanting, narrow from the suture to about the middle and dilated thence to the outer margin $\begin{array}{lllllllll}(\text { pl. xxiii., fig. 22) } & . . & . . & . . & . . & . . & . . & . . & .\end{array}$

$D^{2}$. Elytra with a yellow basal band coalescing with the anterior band.

$a^{2}$. Antennæ yellow with the two basal joints black.

Elytra yellow from the base to the median part, but with three transversely disposed black spots of the background left at some distance from the base ..

The same with a narrow post-median yellow band constricted or broadly interrupted in the centre (pl. xxiii., figs. 23,24$) \quad$.

The same but with the two lateral and sub-median black spots in the anterior part coalescing so as to form a lateral patch, and the yellow basal part does not reach the median part (pl. xxiii., fig. 25) .. ..

Anterior part of elytra yellow from the base to near the median part, lower margin of the yellow band nearly transverse or with the rudiments of a postmedian yellow band reduced to a juxta-sutural transversely ovate patch, and a minute supramarginal yellow dot (pl. xxiii., figs. 26, 27).. ..

tristigma.

testudo.

Anterior part of elytra yellow from the base to the median part, and slightly or distinctly prolonged beyond it along the suture and the outer margin (pl. xxiii., figs. 28,29 ) $\quad$. 
Elytra pale yellow with eight black patches on each side, head and prothorax conspicuously scabrose punctate (pl. xxiii., fig. 32 ) $\ldots$.

$a^{\mathrm{I}}$. Antennal joints black.

Elytra pale yellow from the base to five-sixths of the length, and having in the anterior part three transversely disposed small black dots (background) and a transverse post-median black band interrupted

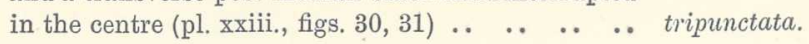

$\mathrm{C}^{x}$. Third basal antennal joint not longer than the fourth.

Elytra with two transverse yellow, yellow and brownishred, or reddish transverse bands.

$\mathrm{D}^{\mathrm{I}}$. Basal part of elytra not covered by the coalescing dorsal or lateral patches and spots.

$a^{\mathrm{x}}$. Antennæ yellow with the two basal joints black.

Basal part of elytra with a minute dorsal yellow spot, and a similar lateral spot, or without any at all, anterior band narrow, little sinuose, posterior one not much broader than the anterior, more or less plainly narrowed towards the outer margin, background from the hind margin of the anterior part to a short distance from the apex reddish brown

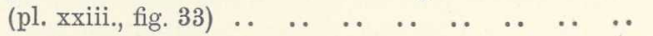

Basal part of elytra with a minute yellow dot, anterior band yellow, narrow, somewhat constricted towards the outer margin, posterior band broader, dark brownish red, and somewhat indistinct (pl. xxiii.,

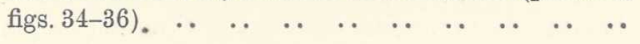

No basal or lateral dot, a very narrow, once or twice interrupted transverse posterior band (pl. xxiii., $\begin{array}{lllllllllll}\text { fig. } 37) & \ldots & \ldots & \ldots & \ldots & . . & \ldots & \ldots & \ldots & \ldots & . .\end{array}$ alterna.

Basal part of elytra without dorsal or lateral spot, anterior band red, broad but narrowed in the lateral supra-marginal part, posterior one also red, as broad in the centre where it is ampliated behind as the anterior, and slightly notched in the anterior margin (pl. xxiii., fig. 38 ) ..

Basal part of elytra with a dorsal yellow patch, and a smaller lateral one, two broad yellow bands of nearly similar width, the hind margins of which are only very slightly sinuose (pl. xxiii., fig. 39) ..

The same, but with the two yellow bands separated by a very narrow space, the two bands coalescing at two points (pl. xxiii., figs. 40,41) .. $\quad$. $\quad$.. $\quad$..

var. irritans.

var. vibex.

dicincta.

Basal part of elytra with a dorsal and a lateral yellow patch or not; anterior yellow band broad, 
slightly narrowed near the outer margin; hind margin slightly or strongly bi-sinuate, posterior of nearly the same width as the anterior, the margins distinctly bi-sinuate, the hind one of the posterior one narrowly edged with orange-red (pl. xxiii., figs. 42, $43,44) \quad$.

matoppoena.

$\mathrm{A}^{\mathrm{T}}$. Elytra with a dorsal and a lateral patch, and two or three zigzagged transverse yellow or red bands.

B3. Head and prothorax with a long silky pubescence.

C. Third basal joint of antennæ longer or as long as the fourth.

D3. Elytra with a basal and a lateral longitudinal yellow bands prolonged respectively along the suture and the outer margin.

$a^{\mathrm{T}}$. Antennæ with the two basal joints black, three to eight fuscous, nine to eleven flavescent.

$b^{2}$. Elytra without an apical transverse patch.

Whole upper side clothed with a dense silky grey pubescence; on the elytra, the dorsal pale yellow band reaches from the base to one-third of the length, the outer marginal one runs to the same length and unites with the anterior narrow, bisinuate dentate band, the posterior is slightly slanting, not wider than the anterior and equally sinuate dentate, or with the sutural longitudinal band, coalescing, except for a small dot left of the background with the anterior band (pl. xxiii., figs. 45, 46)

hilaris.

The same, but anterior band broader and interrupted near the outer margin, posterior one unisinuate and broader at the suture than at the outer margin (pl. xxiii., fig. 47)..

$b^{\mathrm{x}}$. Elytra with an apical transverse patch.

Basal 'sutural band as in the previous species, lateral band continued as far as the second transverse band, which is much narrowed and subhamate near the outer margin, third band extending across the supra-apical part (pl. xxiii., fig. 48) ..

$\mathrm{B}^{2}$. Head and prothorax clothed with a short, appressed, silky grey pubescence.

$D^{2}$. Elytra with a basal dorsal and a lateral patch or spot, and two transverse uneven bands.

$a^{2}$. Antennæ yellow with the three basal joints black.

Elytra black or fuscous black and with a narrow red outer margin broadening considerably past the postmedian band and apex and ascending the suture, a basal dorsal patch and an elongated lateral one, two narrow sharply bi-sinuate yellow transverse bands $\begin{array}{llllllllll}\text { (pl. xxiii., fig. 50) } & . & \ldots & \ldots & . . & . . & . . & . . & \text {.. } & \text { tincta. }\end{array}$ 
$a^{\mathrm{r}}$. Antennæ yellow with the two basal joints black.

Elytra black, more or less broadly marginated all round and also along the suture with brownish red, base with a slanting yellow patch coalescing occasionally by means of a dorsal line with the anterior band, and a lateral patch, anterior and posterior bands narrow, with each margin bi-dentate (pl. xxiii., figs. 51,61$)$..

Elytra with an arcuate basal yellow patch reaching the suture, and an elongated lateral patch, anterior band narrow, the margins three dentate on each side, posterior band also three dentate, strongly narrowed towards the outer margin (pl. xxiii., fig. 52)

derosa.

Base of elytra with a broad, semi-circular band, and a lateral, narrow, elongated patch, anterior band moderately narrow, slightly slanting from the outer margin to the suture, hind margin strongly bi-sinuate, posterior band transverse, narrowed in the centre; bands and patch light orange-red ; under side densely clothed with a greyish silky pubescence (pl. xxiii., $\begin{array}{lllllllllll}\text { fig. } 53) & \text {.. } & \text {.. } & \text {.. } & \text {.. } & \text {.. } & \text {. } & \text {.. } & \text {.. } & \text {.. } & \text {.. }\end{array}$

Whole body covered with a dense, appressed greyish flavescent silky pubescence; a basal dorsal yellow spot, a supra-humeral, elongated patch or band reaching another, but diagonal, dorsal yellow band, lateral basal patch continued as a marginal band as far as the posterior band, the latter also slanting, and continued backwards along the margin to a short distance from the apex (pl. xxiii., figs. 54, 55)

pruinosa.

burmeisteri.

B3. Head and prothorax clothed with a short appressed black pubescence.

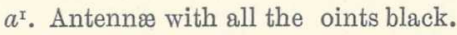

Base of elytra with three yellow patches disposed transversely, anterior band divided into three yellow patches, posterior band strongly zigzagged and usually narrowly interrupted above the outer marginal part (pl. xxiii., fig. 57) $\quad$..

Base of elytra with a dorsal arcuate yellow patch, and a small lateral one, anterior and posterior yellow bands narrow, both strongly zigzagged, anterior one occasionally narrowed on the side

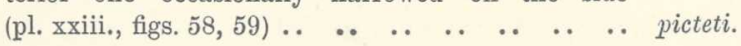

$\mathrm{B}^{2}$. Head and prothorax clothed with an erect, black pubescence.

$D^{x}$. Elytra with a third band, or apical spot.

a. Antennæ black.

Base of elytra with an ovate dorsal patch and a lateral one, anterior bands narrow, sinuate, inter- 
mediate one slanting, bi-sinuate dentate on each margin, broader in the sutural than in the lateral part and connected along the suture with a diagonal supra-apical third band; all the bands and patches red (pl. xxiv., fig. 62)

Base of elytra with a red border, three sub-basal irregular pale yellow patches disposed transversely, median pale-yellow band narrow, strongly zigzagged, posterior one $\mathbf{V}$-shaped, the $\mathbf{V}$ formed by two spurs connected with a supra-apical small central patch (pl. xxiv., fig. 63)

$B^{x}$. Head and prothorax clothed with an erect, and more or less deeply flavescent pubescence.

Head, prothorax, and under side clothed with a dense flavescent pubescence; yellow bands of the elytra invading the greatest part of the surface leaving only a juxta-scutellary and a humeral black patch, three strongly zigzagged very narrow transverse bands and a supra-apical median spot connected with the posterior band (pl. xxiv., fig. 64)

Head, prothorax, and under side clothed with a greyish black pubescence; elytra with a broad basal yellow band with a supra-humeral black spot, the lower edge is plainly denticulate, two ante- and post-median transverse bands reaching from side to side, the first three-dentate on each side, the other nearly interrupted in the centre and also strongly dentate, an apical band formed of two connected patches, which are, however,

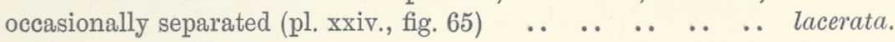

\section{Mrlabris oculata, Thunb., Plate XXII., fig. 1 ; XXIII., fig. 1.}

Nov. Spec. Insect., vi., p. 114, pl. 2, figs. 11a b; Oliv., Entom., iii., 47, p. 4, pl. 11, figs. $11 a b$; Billb., Monogr., p. 47, pl. v., figs. 6-10; Mars., Monogr., p. 42, pl. iv., fig. 3.

Elongated, black, antennæ, with the exception of the two black basal joints, yellow; opaque, spots and bands on the elytra light stramineous yellow; labrum, head and prothorax clothed with a dense, erect, black pubescence, under side similarly hairy; on the legs the pubescence is shorter, and in the inner part of the fore tibiæ it is slightly flavescent, with a silky sheen; the head and prothorax are covered with deep, closely but somewhat irregularly set punctures; on the elytra the punctures are nearly similar, but the black or dark brown background is more coriaceous than the bands, and densely but briefly hairy, the bands or spots are much more briefly hairy and the hairs are much scattered; the under side and legs are very closely aciculate; basal part of elytra with a dorsal, subtransversely ovate yellow patch; under the humeral part, and reaching the outer margin, is a smaller, elongate-ovate patch of the same colour 
occasionally impinging on the humeral part, the two bands are broad, or very broad, of nearly equal width, reaching from the sutural to the marginal fold, the hind border of the post-median band is slightly sinuate and occasionally moderately ampliated at about the median part, and is very narrowly brownish.

Length $23 \frac{1}{2}-34 \mathrm{~mm}$. ; width 9-12 mm.

This species seems to be restricted to the southern part of the Cape Colony, and to Natal and Zululand; above that limit it seems to be replaced by, or merges into, the variety vulgaris.

Var. kakamas,

Plate XXIII., fig. 2.

Shape, size, vestiture and livery of $M$. oculata, but easily distinguished by the deeper, coarser and scrobiculate punctures of the prothorax; the basal dorsal patch is reduced to a minute spot, and the lateral one to a mere dot; the two transverse bands are of nearly equal width throughout, very little sinuated, and both have the hind edge plainly brownish rufous.

Length 28-32 mm.; width $7 \frac{1}{2}-9 \mathrm{~mm}$.

$H a b$. This variety seems restricted to the dry, arid parts of the northwestern part of the Cape Colony.

\author{
Var. vULGARIS, \\ Plate XXIII., fig. 3.
}

Shape, size, and livery of $M$. oculata, differs from the latter by the more closely set and more regular punctures on the head and prothorax; the large basal, dorsal patch on each elytron is reduced to a small yellow spot, and the lateral one to a dot, as in the var. kakamas, and the anterior transverse yellow band is as broad as in $M$. oculata with the borders hardly sinuate, the post-median band is transversely ampliate-ovate from the suture to about the median part, and continued thence to the outer margin as a slightly slanting band reduced to half the width of the median dorsal part; along the hind edge is a broad rufous brown border nearly half as broad as the yellow band at its widest part.

Length $32 \mathrm{~mm}$; ; width $11 \mathrm{~mm}$.

Hab. The whole eastern part of Cape Colony, Natal, Transvaal.

\title{
Var. TRANSITORIA, Plate XXIII., fig. 4.
}

Smaller than the var. vulgaris; sculpture of head and prothorax identical; on the elytra the basal dorsal and lateral spots are very small, the anterior band is however very broad, covering nearly half the length; 
laterally it is connected from the outer margin to the median dorsal part with a much narrower band reaching from the suture to the outer margin, the slightly post-median space of the background left being in the shape of a broad, rufous brown triangle across the suture, the posterior band has a broad edge of rufous brown.

Length 21-23 mm.; width 7-8 mm.

Hab. Natal (Durban, Frere, Maritzburg).

\section{Var. VICARIA, Plate XXIII., fig. 5.}

Shape, size and sculpture of the var. transitoria; differs by the shape of the elytral yellow bands; basal dorsal spot moderately large, lateral small, anterior transverse band broad, the width being about one-fourth of the length, the edges are not sinuate, the posterior band, instead of being entirely yellow, is rufous brown, of nearly the same width as the anterior, and edged in the fore part by a narrow yellow band reaching from the suture to about the middle; near the outer margin is a small yellow dot. This yellow anterior edging of the posterior band is probably uninterrupted in certain examples of this variety, but I have not as yet met with any such.

Length $24 \mathrm{~mm}$; width $7 \mathrm{~mm}$.

Hab. Natal (Durban).

$$
\begin{aligned}
& \text { Var. TRICoLOR, Gerst., } \\
& \text { Plate XXIII., fig. } 6 .
\end{aligned}
$$

Monatsb. Berl. Acad., 1854, p. 694 ; Peter's Reis., 1862, p. 297, pl. 17, fig. 11; Mars., Mon., p. 461, pl. 5, fig. 39.

Head and prothorax very finely punctulate; basal dorsal yellow patch transversely ovate, lateral one nearly as large, anterior band yellow, very broad, the width being equal to half the length, and the posterior edge is slightly bisinuate, the posterior band is red, only one-third of the width of the anterior, and slightly narrowed at the suture and at the outer margin which makes it look as if it were transversely ovate.

Length 29-31 mm.; width 11-12 mm.

Hab. Southern Rhodesia (Matoppos, Salisbury, Sebakwe), Mozambique (Lourenço Marquez, Beira).

\section{Var. AMATONGA, Plate XXIII., fig. 7.}

Smaller than $M$. tricolor, sculpture and vestiture similar, the basal dorsal yellow patch is small, and the lateral one has disappeared; the anterior yellow band is much less broad than in $M$. tricolor, being at its 
widest part only one-third of the length; from the suture to the second dorsal stria it is of equal width and gradually narrowed thence to the outer margin where it is one-fourth narrower than at the suture; the posterior band is transversely ovate and does not reach quite either suture or outer margin, it is rufescent, but the inner part of the fore edge is more or less broadly yellow.

Length 25-27 mm. ; width 9-10 mm.

$\mathrm{Hab}$. Amatongaland.

I have not recorded this species from anywhere but the Maputa River.

Var. ноттелтота, Făhr., Plate XXIII., fig. 8. Öfv. Vet. Ak. Förh., 1870, p. 341.

transversalis, Mars., Monogr., p. 400, pl. iv., fig. 2.

Closely allied to $M$. tricolor, but the basal dorsal patch is reduced to a tiny yellow dot, and the lateral one is obliterated; the anterior yellow band is very broad, the width being about equal to two-fifths of the length, the edges are not sinuate; this yellow band is separated from an equally broad rufous brown band of the same shape which is, however, occasionally somewhat narrower; in some examples the yellow and the rufous brown band coalesce.

Length 23-29 mm. ; width 9-13 mm.

Hab. Natal (Durban, Tugela River).

$$
\begin{aligned}
& \text { Var. MYOPs, Făhr., } \\
& \text { Plate XXIII., fig. } 9 .
\end{aligned}
$$

Öfv. Vet. Akad. Förh., 1870, p. 341; Mars., Monogr., p. 404, pl. 4, fig. 4.

Sculpture of the varieties tricolor, hottentota, \&c., but usually smaller; basal dorsal patch very small, ovate or briefly transverse, yellow, like the very small lateral spot; anterior band yellow, narrow, being only equal to one-fifth of the whole length, slightly sinuate and slightly narrower at the outer margin than at the suture; at some distance from this anterior band is a post-median and much broader reddish brown one of nearly equal width reaching from the suture to the outer margin, and the edges of which are not sinuate.

Length 24-26 mm.; width $8 \frac{1}{2}-10 \mathrm{~mm}$.

Hab. Damaraland; Ovampoland.

I have seen a female example having a minute median yellow dot on the edge of the rufescent posterior band.

Marseul wrongly quotes Chevrolat as having described this species in Guérin's Iconogr., 1844, p. 123, pl. 35, fig. 4. The figure is undoubtedly that of $M$. hamacta, Fairm., var. namaqua. 
It is also probable that Făhræus' species is not identical with $M$. myops, Dej., in litt., because the habitat of this species seems to be restricted to parts which had not been entomologically explored at the time of Dejean.

$$
\begin{aligned}
& \text { Mylabris BRUqueti, Mars., } \\
& \text { Plate XXIII., fig. } 10 . \\
& \text { Monogr., p. } 410 .
\end{aligned}
$$

Body very elongated; prothorax more deeply punctate than in the previous species, the punctures uneven and sub-scrobiculate in the posterior part of the disk; elytra piceous, each one with a minute basal dorsal yellow spot and no lateral one, or without the basal spot, anterior band yellow, narrow, not quite as broad near the outer margin as it is at the suture, posterior one either of the same width as the anterior or a little broader from the suture to about the middle, and narrowed thence to the outer margin, the width being reduced there to about onehalf, the hind edge has either a very slender brownish margin, or a not very distinct, somewhat broad band of the same colour; legs and under side very closely aciculate.

Length 29-32 mm.; width 91-10 mm.

Hab. Damaraland; Ovampoland.

Marseul (loc. cit.) has indicated rather than described the species.

\section{Mrlabris versuta, n. sp., Plate XXIII., fig. 11.}

Black; head and prothorax covered with moderately deep punctures separated by a smooth interval about equal to their own diameter; the pubescence long, dense, black; elytra without dorsal or lateral yellow patch, anterior band yellow, not broad, narrowed from about the median part to the margin, and with the hind border moderately deeply scooped out in the centre, posterior band orange-yellow, somewhat slanting, broader than the anterior, slightly scooped in the centre in the anterior margin, and emitting a short, blunt tooth in the middle of the hind one, which is also more sinuose.

Length $21 \mathrm{~mm}$; width $8 \frac{1}{2} \mathrm{~mm}$.

Hab. Damaraland (Salem).

$$
\begin{aligned}
& \text { Mylabris HybRIDA, Mars., } \\
& \text { Plate XXIII., fig. } 12 . \\
& \text { Monogr., p. 418, pl. iv., fig. } 2 .
\end{aligned}
$$

Black, with the elytra brownish, turning to piceous in the posterior part; head and prothorax very closely punctate, especially the latter, 
pubescence long, dense, black; elytra with a round, basal, dorsal yellow patch, and an elongated lateral spot, anterior band yellow, narrow, somewhat constricted in the centre, posterior one also yellow, not much wider than the anterior, broadly interrupted in the centre, and thus divided into a sutural and a marginal patch, the latter shorter and not quite as wide as the former; these spots and bands are edged with reddish brown.

Length 15-16 mm.; width $6 \mathrm{~mm}$.

Hab. Damaraland.

$$
\begin{aligned}
& \text { Mylabris scalaris, Mars., } \\
& \text { Plate XXIII., figs. 13, 14, } 15 . \\
& \text { Monogr., p. 407, pl. iv., fig. } 6 .
\end{aligned}
$$

Black; antennæ reddish yellow, with the three basal joints black, head and prothorax covered with closely set, moderately deep punctures, pubescence long, dense, black; elytra with a basal dorsal large orangeyellow patch somewhat transverse, but occasionally reaching the suture and coalescing there with the anterior band, no lateral spot; anterior band orange-yellow, very broad at the suture, but triangularly narrowed. thence to the outer margin where the width is reduced by about one-third, the posterior band is narrower than the anterior, also broader at the suture, somewhat slanting towards the outer margin where it is also reduced in width by about one-third, and both the edges are bi-sinuate; the space separating the two bands is extremely narrow across the suture, and often the posterior is connected there with the anterior band.

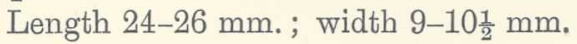

Hab. Northern Damaraland.

\section{Mylabris tettensis, Gerst., Plate XXIII., fig. 16.}

Monatsb. Berl. Acad., 1854, p. 694 ; Peter's Reis., p. 298, pl. 17, fig. 12 ; Mars., Monogr., p. 422, pl. iv., fig. 14.

Black; antennæ yellow, with the four basal joints black; head and prothorax covered with round punctures separated from each other by a quite smooth interval equal to their own diameter; the pubescence is long and ereet, but not very dense, and in the frontal part the impressed line is hardly distinct; elytra without dorsal or lateral basal patch or spot, the anterior band, which ascends in the median part towards the base, is very broad, orange-yellow, and the hind border is slightly bi-sinuate, the posterior is not quite as broad as the anterior, and its width is narrowed laterally by one-third, the hind border is sinuose.

Length $26 \mathrm{~mm}$; width $9 \mathrm{~mm}$.

Hab. Mozambique (Beira). 
Mrlabris plagiata, Pall.,
Plate XXIII., figs. 17, 18.

Icon., p. 77, pl. E, fig. $3 a$; Mars., Monogr., p. 405, pl. iv., fig. 5.

oculata, Billb., Monogr., p. 46, pl. 5, figs. 6-10.

thunbergi, Cast., Hist. Nat. Ins., ii., p. 269.

Black, with the patches and bands on the elytra bright yellow; between the two transverse bands of the elytra is a juxta-sutural longitudinal rufescent band reaching from the suture to the centre; antennæ bright yellow, with the five basal joints black; head and prothorax coarsely punctate, the impressions on the latter very deep, pubescence long, dense, black; elytra each with a more or less rounded dorsal basal patch, but without any lateral one, anterior band narrow, broadening slightly along the outer margin, the edges little sinuate, posterior band either very little wider than the anterior, a little acuminate at both ends and plainly bi-sinuate on each border (fig. 17), or broadly dilated laterally, where it is twice the width of the part abutting near the suture (fig. 18). The pubescence of the under side is black, but in the varietal form it is greyish flavescent.

Length 22-24 mm.; width $8 \mathrm{~mm}$.

Hab. Cape Colony (Worcester, Hex River, Prince Albert, Paarl, Ceres, Beaufort West).

\author{
Mylabris hamacta, Fairm., \\ Plate XXIII., fig. 19.
}

Ann. Soc. Ent. Fr., 1888, p. 198.

Head and prothorax still more coarsely punctate than in M. plagiata; the two basal antennal joints are black, and the other three infuscate, the impressions on the prothorax are very distinct, and the pubescence is dense and black; on the elytra there is no basal dorsal yellowish patch; the anterior band is very narrow, not sinuate, pale yellow edged with a sub-orange-brown narrow border, the posterior band is orange-yellow, strongly slanting, and in width a little more than two-fifths of the length with the borders not sinuate, the anterior edge has a narrow, sub-orangebrown border.

Length $25 \mathrm{~mm}$; width $8 \mathrm{~mm}$.

Hab. Cape Colony (Kakamas). 


\author{
Var. NAMAQUA, \\ Plate XXIII., fig. 20.
}

oculata, Guér., Icon. Règn. Anim. Ins., 1844, p. 133, pl. 35, fig. 4. myops, Mars., Monogr., p. 404, pl. iv., fig. 4.

This variety so closely resembles $M$. lavaterce that it might be taken for the latter in spite of a difference in the shape of the markings of the elytra, the bands and spots of which are however of the same colour, but the antennæ are plainly yellow with the five basal joints black instead of being entirely fuscous black; head and prothorax very finely and closely punctate, the punctures however are irregular, impressions on the disk very plain; elytra with a rounded dorsal basal yellow patch, no lateral, anterior band moderately narrow, the edges suffused with orange, posterior band very broad, not slanting, orange-yellow, the edges hardly sinuate, but the hind one slightly rounded.

Length $27 \mathrm{~mm}$, ; width $10 \mathrm{~mm}$.

Hab. Cape Colony (O'Kiep, Namaqualand).

\title{
Mrtabris Lavatere, Fábric.,$$
\text { Plate XXIII., fig. } 21 .
$$

Syst. Eleuth., ii., 1801, p. 83 ; Billb., Monogr., p. 10, pl. 1, fig. 7; Mars., Monogr., p. 45a, pl. v., fig. 38.

pustulata, Thunb., Diss. Ins. Nov. Sp., vi., p. 114 ; Oliv., Ent., iii., 47, p. 4, pl. 1, fig. 1 .

Head and prothorax very closely punctulate, the punctures small, deep but uneven; the five antennal basal joints black, the others black, opaque, or very darkly fuscous; pubescence on the head and prothorax dense, long, black; elytra with an ovate orange-yellow basal dorsal patch, the anterior band is somewhat narrow, incised on each side in the middle but the lower incision is the deeper of the two, or it is broader but the lateral part, from the incision to the outer margin, is narrower than the part abutting on the suture, posterior band also orange-yellow, broader than the anterior, slanting from the median dorsal part to the outer margin, hind border sub-sinuate or uni-sinuate.

Length 23-25 mm.; width $8 \mathrm{~mm}$.

Hab. Cape Colony (Paarl, Ceres, Tulbagh, Worcester).

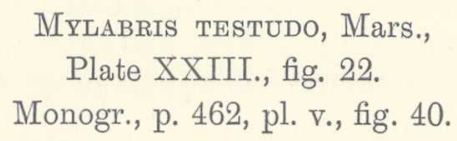

Black, elytra with a longitudinal, nearly median, rufescent zone reaching from the anterior to the posterior transverse bands, pubescence 
black above, ashy flavescent and silky underneath; the five basal antennal joints black, the others deeply fuscous, nearly black; elytra each with a more or less rounded orange-yellow patch, no lateral spot, anterior band also orange, interrupted in the centre, and thus divided into an ovate patch near the suture and a triangular one the base of which extends along the outer margin; posterior band narrow and transverse from the suture to the centre, and with the lower part developed into a more or less quadrate patch reaching the outer margin. The livery is not unlike that of $M$. plagiata, but the colour of the antennæ easily differentiates the two.

Length $19 \mathrm{~mm}$; ; width $6 \frac{1}{2}-7 \mathrm{~mm}$.

Hab. Cape Colony (Victoria West, Beaufort West).

Mylabris tristigma, Gerst.,

Monatsb. Berl. Acad., 1854, p. 694 ; Peter's Reis., 1862, p. 299, pl. 17, fig. 5 ; Mars., Monogr., p. 429, pl. 4, fig. 19.

Black, clothed with black hairs on the under side, the legs, head, and prothorax; antennæ yellow with the two basal joints black, third joint not much longer than the fourth, but cylindrical; the anterior part of the elytra from the base to slightly past the median part is light straw-yellow, but at about one-half of the distance between the base and the hind margin are three small, transversely situated round spots, the hind margin is more or less strongly bi-sinuate ; the yellow part is somewhat densely pubescent, the pubescence being black and erect.

This typical form seems to be the rarest, and I have not met with it.

Length $17 \frac{1}{2} \mathrm{~mm}$.

Hab. Mozambique.

\section{Var. PERMUtANS, Plate XXIII., figs. 23, 24.}

Like the type, but in addition to the anterior bands which have by coalescence invaded the whole anterior part of the elytra, except for the three round spots of the colour of the black ground which remain as vestiges of the part that divided the original two bands, there is a posterior narrow, yellow band, either strongly strangulated (pl. xxiii., fig. 24), or as often as not interrupted in the centre, and thus reduced to two patches (pl. xxiii., fig. 23), a juxta-sutural and a juxta-outer marginal one, divided by a very narrow or narrow interval.

Length 16-23 $\mathrm{mm}$. ; width 6-7 mm.

Hab. Southern Rhodesia (Salisbury, Mazoe, Matoppos). 
Var. FLAviconNis, Făhr.,

Plate XXIII., fig. 25.

Öfv. Vet. Akad. Förhdl., 1870, p. 342.

bipartita, Mars., p. 427, pl. iv., fig. 17.

The livery resembles that of $M$. tristigma; elytra suffused with yellow from the base to two-fifths of the length only, instead of past the middle ; in this yellow part the median and the outer marginal black spot have coalesced so as to form a very distinct black transverse patch; the hind border is slanting from the margin to the suture, and is weakly bi-sinuate; the posterior band is reduced to two yellow spots of a moderate size, one juxta-sutural, and the other much smaller, situated near the edge of the outer margin. It is probable that the size of these two spots is variable.

Length $14 \frac{1}{2}-19 \mathrm{~mm}$. ; width $5 \frac{4}{5}-7 \mathrm{~mm}$.

Hab. Natal (Durban).

\author{
Var. STĂLI, Făhr., \\ Plate XXIII., figs. 26, 27. \\ Öfv. Vet. Ak. Förhdl., 1870, p. 343.
}

Black, covered with a long, black pubescence; antennæ yellow with the two basal joints fuscous or black, third joint longer than the fourth; head and prothorax closely punctate; elytra shagreened. Elongated; elytra piceous or piceous rufescent along the suture; the whole of the anterior part is yellow from the base to two-fifths of the length, the hind border is slightly slanting from the outer margin to the suture, and there is either no distinct post-median yellow band or patches, or a distinct subjuxta-sutural one and a minute supra-marginal dot on the posterior part.

Length $15 \mathrm{~mm}$.; width $6 \mathrm{~mm}$.

Hab. Naf́al (Eshowe, Karkloof, Durban).

\author{
Mrlabris palliata, Mars.,$$
\text { Plate XXIII., figs. 28, } 29 .
$$$$
\text { Monogr., p. 432, pl. iv., fig. } 22 .
$$

Smaller and more elongated than M. bipartita; it is easily distinguished by the antennal joints, the intermediate ones of which are much more - closely set and not turbinate as in the latter. Head with a conspicuous median longitudinal frontal smooth line; both the head and prothorax are deeply and closely punctate, the punctures rugose, especially on the disk ; the pubescence is black and long; elytra plainly coriaceous or subshagreened; the anterior part is dull orange-yellow from the base to the median part and occasionally beyond it, and the hind border is strongly 
tri-sinuate, the outer marginal angle extending sometimes considerably further than the sutural (fig. 28); occasionally this border is produced into a short ramus, dilated at apex towards the median part, and is interrupted along the outer margin (fig. 29).

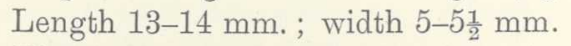

Hab. Southern Rhodesia.

$$
\begin{aligned}
& \text { Mrlabris tripunctata, Thunb., } \\
& \text { Plate XXIII., figs. } 30,31 .
\end{aligned}
$$

Diss. Nov. Ins. Spec., vi., p. 112 ; Billb., Monogr., p. 29, pl. 3, figs. 14-16 ; Mars., Monogr., p. 486, pl. v., fig. 49.

Black, clothed with a dense black pubescence; antennal joints black, third joint nearly twice the length of the fourth; head and prothorax finely and closely aciculate punctate, frontal line indistinct; elytra light yellow, the yellow colour having invaded the background to such an extent that the black background is reduced to three small black spots disposed somewhat diagonally in the anterior part; past the middle are two black patches of the same colour which vary in size, but the onter or marginal is larger than the juxta-sutural, and at the apex there is left a moderately broad, sinuate black band of the original colour; the elytra are coriaceous, and each bears three distinct costules.

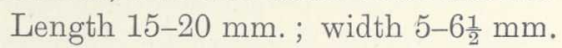

Hab. Cape Colony (Stellenbosch, Worcester, Paarl, Malmesbury, Namaqualand, Beaufort West).

$$
\begin{aligned}
& \text { Mylabris Connexa, Mars., } \\
& \text { Plate XXIII., fig. } 32 . \\
& \text { Monogr., p. } 505 \text {, pl. v., fig. } 58 .
\end{aligned}
$$

Black, somewhat opaque; head and prothorax very closely scabrose punctate, frontal part with a small smooth patch, pubescence black, dense, erect; antennæ yellow, with the two antennal joints black, the intermediate joints closely set, third plainly longer than the fourth; elytra very closely punctate, the punctures deep but not rugose, the pale straw-like colour has invaded the greatest part of the area, leaving however on each side along the outer margin a long humeral black band, a median and a post-median patch of moderate size, and a small apical sutural one; on the disk are two patches, one anterior and one post-median, a small median dot in the centre of the disk, and close to it a very short transverse black patch astride the suture, which spot and patch are probably coalescing occasionally.

Length 10-14 mm. ; width $6 \mathrm{~mm}$.

Hab. Cape Colony (Stellenbosch, Paarl, Worcester). 


\section{Mrlabris alterna, Cast., Plate XXIII., fig. 33.}

Hist. Natur. Ins., ii., 1840, p. 270 ; Mars., Monogr., 1873, p. 410, pl. iv., fig. 8.

Black, moderately shiny; head and prothorax very closely punctate, the punctures round, nearly contiguous, the pubescence black, dense, erect; on the frontal part the smooth, raised line is very plain, and the impressions on the prothorax are very marked; antennæ bright yellow, with the two basal joints black, the third one not appreciably longer than the fourth; elytra closely coriaceous and briefly pubescent, on the basal part is a small yellow dorsal spot, as often as not quite obliterated, but no lateral one; before the median part is a yellow transverse narrow band of nearly equal width throughout, the hind border of which does not reach the median part; past the median part is another transverse yellow band nearly equal in width to the anterior one but occasionally narrowed towards the outer margin; the dorsal space from the hind border of the anterior band to a short distance from the apex is rufescent brown except for a narrow space along the outer margin.

Length 18-26 mm. ; width $6 \frac{1}{2}-9 \mathrm{~mm}$.

Hab. Cape Colony (Seymour, East London), Natal and Transvaal (probably the whole of these two territories).

\section{Var. viBEX, Plate XXIII., fig. 37.}

Closely resembles the type form, but differs in the markings of the elytra; the basal spots are entirely obliterated, the ante-median yellow band is normal, but the post-median is very narrow and interrupted shortly before the median part. This variety is very rare.

Length $20 \mathrm{~mm}$; ; width $7 \mathrm{~mm}$.

Hab. Natal.

\section{Var. IRRITANS,} Plate XXIII., figs. 34, 35, 36.

Resembles the type, but the posterior yellow band is completely obliterated, and is replaced by a dull rufescent one seldom reaching the outer margin ; there is occasionally a minute yellow dorsal basal dot, and the first yellow band, which is of nearly equal width in the male, is broader and narrowed towards the outer margin in the female.

Length 21-26 mm.; width 8-10 mm.

Hab. Natal (Durban). 


\section{Mrlabris dicincta, Bertol., Plate XXIII., fig. 38.}

Nov. Commn. Act. Bonon., x., 1849, p. 419 ; Mars., Monogr., p. 408, pl. iv., fig. 7.

bizonata, Gerst., Monatsb. Berl. Ak., 1854, p. 694 ; Peter's Reis., 1862, p. 298, pl. 17, fig. 13.

Black, shiny; head and prothorax very closely punctate, the punctures nearly contiguous and somewhat rugose laterally on the prothorax, pubescence dense, black, frontal part with a plain, smooth line ; antennæ bright yellow, with the two basal joints black, third joint not longer than the fourth; black background of elytra plainly shagreened, the red bands deeply and irregularly punctate, but with the space between the punctures not rugose, the third costule is obliterated from near the median part; there are two orange-red transverse bands reaching from side to side, and both slightly narrowed from the median dorsal part towards the outer margin, the posterior band is notched in the centre of the anterior border, and somewhat ampliated towards the centre in the posterior.

Length $27 \frac{1}{2} \mathrm{~mm}$; width 9-10 mm.

Hab. Southern Rhodesia (Salisbury, Sebakwe, Mozambique).

\section{Mrlabris tripartita, Gerst., Plate XXIII., fig. 39.}

Monatsb. Berl. Acad., 1854, p. 694 ; Peter's Reis., 1862, p. 299, pl. 17, fig. 14 ; Mars., Monogr., p. 430, pl. 4, fig. 20.

Black; head and prothorax almost contiguously aciculate; pubescence dense, black; frontal part without any distinct traces of a longitudinal smooth line, antennæ yellow with the two basal joints black, and the third not longer than the fourth; elytra coriaceous except on the yellow bands, there is on each side a dorsal, either small or large basal pale yellow patch, a small lateral one, and two pale yellow bands; the anterior one is either broader or slightly broader than the second, but both are very little sinuate, the edges being mostly always nearly straight. In general appearance and coloration this species somewhat resembles small examples of $M$. oculata.

Length $20 \mathrm{~mm}$; width $7 \mathrm{~mm}$.

Hab. Southern Rhodesia (Salisbury).

\section{Var. MAKaLANGa, Plate XXIII, figs. 40, 41.}

Size, shape and sculpture of the type form $M$. tripartita; differs however from the type in having the two transverse yellow bands on the 
elytra broad and separated from each other by a narrow line-like space (fig. 40), or the two bands coalesce, leaving only two or more minute spots of the colour of the original background (fig. 41); the hind edge of the posterior band is weakly sinuate.

Length $19 \mathrm{~mm}$.; width $7 \mathrm{~mm}$.

Hab. Southern Rhodesia (Salisbury).

\section{Mrlabris matoppoena, Plate XXIII., figs. $42,43,44$.}

Black, shiny; head and prothorax very closely aciculate; pubescence dense, black, frontal part with a distinct smooth elongated spot; elytra with a basal, dorsal yellow patch and a small lateral dot, or entirely without traces of either, the two somewhat dark yellow bands are broad, the anterior is narrower at the outer margin than on the suture, and with the hind border either not sinuate or slightly tri-sinuate, posterior band either narrowed also towards the outer margin or not, and with the anterior border plainly tri-sinuate, the hind one slantingly emarginate near the suture, and slightly sinuate near the median part, both the posterior borders are narrowly edged with reddish brown.

This form greatly resembles specimens of $M$. oculata of moderate size.

Length 25-27 mm. ; width $8 \frac{3}{4}-9 \mathrm{~mm}$.

Hab. Southern Rhodesia (Salisbury, Matoppos).

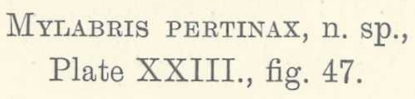

Black, clothed on the upper and under side with a long, greyish flavescent silky pubescence nearly as long on the elytra as on the head and prothorax; antennæ black, with the five apical joints fuscous and faintly flavous; head and prothorax very faintly aciculate and having a plain elongated frontal smooth patch; prothorax very closely aciculate, the punctures very closely set and round; elytra equally shagreened on the background and on the yellow bands, each with a long dorsal pale yellow band reaching from the base to one-third of the length, a median, transverse, bi-dentate one narrowly interrupted near the outer margin where there is a triangular part connected with a lateral narrow band reaching the base, and a posterior broadly triangular between the suture and the median discoidal part, and narrow thence to the outer margin, where it expands a little along the edge. Possibly a varietal form of $M$. hilaris.

Length 10-11 mm.; width $4 \mathrm{~mm}$.

Hab. Southern Rhodesia (Victoria Falls), Natal (Durban). 
Mylabris hilaris, Pér., Plate XXIII., figs. 45, 46.

Trans. S. Afric. Phil. Soc., vi., 1892, p. 63.

Size, colour, sculpture and pubescence similar to that of $M$. pertinax and $M$. villosa, the dorsal very pale yellow band reaches also to one-third of the length, but it occasionally coalesces with the anterior transverse band, this band being connected laterally with a narrow yellow marginal one reaching the base, the anterior edge of the transverse band is deeply emarginate in the centre, the posterior is plainly bi-incised there, and reaches also the outer margin, expanding there alongside of it so as to be slightly connected there with the anterior; it is slightly slanting from the suture, the fore border is sinuate near the suture and incised in the centre, the hind border is bi-incised. When the dorsal longitudinal band meets the anterior transverse one, there is a small dot of the background still left visible.

Length $10 \frac{1}{2}-12 \mathrm{~mm}$.

Hab. Ovampoland.

\section{Mylabris holosericea, Klug,}

Plate XXIII., fig. 48.

Erm. Reis., 1835, p. 31; Mars., Monogr., p. 142, pl. v., fig. 56.

villosa, Făhr., Öfv. Vet. Ak. Förhdl., 1870, p. 345.

Black, clothed on the upper and under sides with a dense silky flavescent pubescence; antennæ black fuscous, but with the five apical joints slightly flavous; head and prothorax closely aciculate; elytra elongated, narrow, each with a narrow pale yellow marginal band reaching from the basal part of the shoulder to a very short distance from the apex, in the anterior part is a longitudinal dorsal band reaching to about one-third of the length, the anterior transverse band is reduced to a transverse patch broadly separated from the outer margin, the posterior band is moderately broad, sub-transverse from the suture to the median dorsal part and narrowed thence to the outer margin in which it merges; on the rounded part of the apex extends a transverse yellow patch narrowly divided from the suture and the posterior and lateral margins.

Length $12 \mathrm{~mm}$; ; width $4 \mathrm{~mm}$.

Hab. Southern Rhodesia (Salisbury).

Occurs also in Senegambia. 
Mylabris tincta, Erichs., Plate XXIII., fig. 50.

Wiegm. Arch., 1843, i., p. 256.

Mars., Monogr., p. 171, pl. v., fig. 61.

Black, covered on the head and prothorax with a long, dense, thick silky flavescent pubescence which is also moderately dense but very short on the black parts of the elytra, and somewhat more sparse and intermixed with a few black hairs on the sub-orange-yellow bands; antennæ of the normal Mylabrid shape, and with the four basal joints black, the others flavescent red; head and prothorax covered with very closely set, slightly rugose punctures; the short frontal median ridge is quite distinct, and the post-median narrow longitudinal impression quite deep; the elytra are covered with contiguous, somewhat deep punctures with subrugose walls imparting to them a moderately rough, shagreened appearance, the basal dorsal patch is round, or very slightly slanting and free, the lateral is elongated, but does not, in my examples, reach beyond the length of the dorsal patch, the juxta-median transverse band is narrow, but broader towards the suture than towards the outer margin with the fore border deeply notched twice and the posterior still more deeply incised; the post-median band is quite similar, and both reach only the edge of an outer marginal red band beginning at the apex of the lateral elongated patch, and increasing in width below the posterior transverse band, greatly enlarged at the apical part and ascending along the suture, where it is however not wider than on the anterior part of the outer margin.

Length 13-141 $\mathrm{mm}$.; width $5 \frac{1}{2} \mathrm{~mm}$.

Hab. Damaraland (Walfish Bay, Svakop River).

\section{Mylabris matabele, n. sp., Plate XXIII., figs. 51, 61.}

Black, clothed on the under side with an appressed thick silky flavescent pubescence equally dense on the head and prothorax; elytra rufous brown, maculated with fuscous, or with the greatest part of the disk fuscous, but the margin and the suture are narrowly reddish brown, bands and patches light orange-yellow; antennæ rufescent yellow with the two basal joints black, third joint very slightly longer than the fourth; head and prothorax very closely and deeply punctate, the punctures uneven especially on the sides of the prothorax ; elytra closely coriaceous, each with a basal dorsal yellow patch and a very distinct lateral one, an ante-median band reaching from the suture to the margin, somewhat narrow and with both edges bi-incised, posterior band of nearly equal width; the basal dorsal patch does occasionally emit a spur connecting 
it with the anterior band which, like the posterior, has both margins very deeply incised, and both are broadly disconnected from the outer margin. In some examples the fuscous dorsal part is divided into three superposed patches.

Length $12-13 \mathrm{~mm}$. ; width $5 \frac{1}{2}-6 \mathrm{~mm}$.

Hab. Southern Rhodesia (Matoppos); Bechuanaland (Moroqueng, Kenya).

\section{MYlabris DERosa, n. sp., Plate XXIII., fig. 52.}

Black, covered with a dense, appressed, silky, flavescent pubescence on the under side, head, and prothorax; antennæ rufescent yellow with the two basal joints black, the third joint slightly longer than the fourth; head and prothorax very closely and finely punctate, the former with a very indistinct frontal smooth macule, the latter with a deep median discoidal impression; background of elytra very deeply and closely punctate, the punctures somewhat roughened, giving the appearance of a slightly shagreened surface, the yellow bands and patches are coriaceous only, on each side is a basal dorsal lunule the arcuate part of which reaches the suture, and a moderately large lateral patch, the anterior band reaches from the suture to the outer margin, the anterior border is shallowly bi-incised, the posterior plainly tri-dentate; the post-median band is broad along the suture, and tapers strongly from the centre to the outer margin, the fore border is deeply tri-sinuate, and the hind one bi-sinuate.

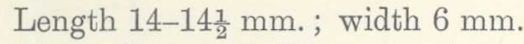

Hab. Transvaal (Pietersburg).

\section{Mylabris pruinosa, Gerst., Plate XXIII., fig. 53.}

Monatsb. Berl. Acad., 1854, p. 694 ; Peter's Reis., 1862, p. 302, pl. 18, fig. 2 ; Mars., Monogr., p. 443, pl. iv., fig. 28.

Under side, head, prothorax, and scutellum clothed with a very dense, appressed, silky, light flavescent pubescence ; antennæ rufescent yellow with the two basal joints black, third joint as long as the fourth, and both sub-cylindrical; in addition to the appressed flavescent hairs the head and prothorax bear some erect black hairs; head and prothorax very closely punctate, the former with a distinct frontal longitudinal raised line; elytra strongly coriaceous even on the orange-yellow patches or bands, with the pubescence somewhat long, flavescent and greyish, each elytron with a large, rounded basal dorsal band, and a lateral elongated patch, the moderately narrow anterior band is slightly slanting from the 
outer margin to the suture, and its hind border is very deeply bi-sinuate, posterior band of the same width, moderately deeply emarginate in the centre of the anterior border, and moderately arcuate in the posterior.

Length $14 \mathrm{~mm}$. ; width $5 \frac{1}{2} \mathrm{~mm}$.

Hab. Rhodesia, Feira; Zambesi River; Victoria Falls.

\section{Mrcabris burmeisteri, Bertol., Plate XXIII., figs. 54, 55.}

Nov. Comm. Ac. Bon., x., 1849, p. 420, pl. 9, fig. 8; Mars., Monogr., p. 437, pl. iv., fig. 24.

Black, with the upper side, the head, prothorax, and scutellum thickly clothed with a greyish flavescent pubescence, elytra covered with a similar pubescence, but so arranged in well-preserved examples that the sculpture shows as distinct fossulate punctures; antennæ rufescent yellow with the two basal joints black, the third of nearly equal length with the fourth; head and prothorax deeply pitted; elytra each with a basal dorsal, sub-juxtasutural yellow patch, a supra-humeral, sub-basal elongated one, the apex of which is very close to if not connected with two small patches disposed diagonally from the median part towards the suture, and as often as not having coalesced so as to form a diagonal band, the basal lateral patch is continued as a narrow band from the humeral angle to, but not connected with, a transverse post-median band, occasionally narrowly interrupted in the centre, and reaching from the suture to the outer margin, where it is prolonged backwards as a narrow band stopping short of the rounded part of the apex.

Very distinct from all the other South African species owing to its livery and the disposition of the yellow bands.

Length $11 \frac{1}{2} \mathrm{~mm}$. ; width $15 \mathrm{~mm}$.

Hab. Cape Colony (Kimberley, Douglas); Transvaal (Rustenburg).

\section{Mylabris sedecimguttata, Thunb.,} Plate XXIII., fig. 57.

Diss. Nov. Insect. Sp., vi., p. 115, fig. 20 ; Billb., Monogr., p. 42, pl. 5, fig. 1 ; Mars., Monogr., p. 479, pl. v., fig. 47.

Black, moderately shiny, densely but briefly pubescent, the pubescence black, not shiny; antennæ black, the third joint one-third longer than the fourth; head and prothorax very closely punctured, the former is without any frontal smooth spot or line, the latter is one-fourth broader than long, ampliate rounded laterally in the anterior part, and truncate in front, the central and basal impressions are distinct, but there are no traces of a longitudinal smooth or raised line; elytra somewhat short and massive, 
very closely punctate, coriaceous shagreened, each bears three basal small yellow patches disposed transversely, the first two are dorsal, the third lateral; towards the median part are three similarly disposed, but slightly wider patches, and the posterior band consists of a strongly zigzagged band reaching from the suture to past the middle dorsal part, and of a small supra-marginal patch closely approaching the remainder of the band, and probably occasionally coalescing with it; all these patches and band are narrowly edged with brown.

The shape of the prothorax in this species, and in the following, differs from that of the other South African Mylabris.

Length 18-21 mm.; width 8-9 mm. River).

Hab. Cape Colony (Port Elizabeth, Grahamstown, Knysna, Sunday's

\author{
Mylabris picteti, Mars., \\ Plate XXIII., figs. 58, 59. \\ Monogr., p. 480, pl. v., fig. 48.
}

Allied to the preceding species; black, with the elytra brown, antennæ also completely black, the patches and bands of elytra lighter yellow; shape of head and prothorax similar, but the punctuation is deeper, the walls of the punctures are raised and irregular, the pubescence is also shorter, the discoidal part of the prothorax is deeply depressed, and the median longitudinal line is very distinct; on the elytra which are almost shagreened, the two basal dorsal patches have coalesced, as have also the three patches in the median part which have thus become a moderately narrow band both edges of which are deeply tri-sinuately incised; occasionally however this band is very narrowly interrupted towards the side; the posterior band is tapering from the middle to the outer margin, and strongly zigzagged there.

Length $16-17 \mathrm{~mm}$.; width $6 \frac{1}{4} \mathrm{~mm}$.

Hab. Transvaal (Pretoria, Rustenburg).

$$
\begin{gathered}
\text { Mylabris coeca, Thunb., } \\
\text { Plate XXIV., fig. } 62 .
\end{gathered}
$$

Diss. Nov. Insect. Sp., vi., 112, 1791, figs. 11-12 ; Billb., Monogr., p. 34, pl. 4, figs. 6-9.

ochroptera, Gmel., Edit. Lin., i., 4, p. 2020.

picta, Oliv., Ent., iii., 42, p. 9, pl. 1, fig. 3 ; Billb., Mon., p. 23, pl. 2, fig. 14 ; Mars., Monogr., p. 487, pl. v., fig. 40.

Black, clothed with a dense, black pubescence, antennæ completely black, third joint longer than the fourth, both very elongated; elytral 
patches and bands orange-red; pubescence black, erect; head and prothorax deeply punctate, the punctures uneven and very closely set; elytra with the black background very closely aciculate, the spots and bands with irregularly scattered punctures; elytra elongated, each with an elongate ovate basal dorsal patch, and a smaller lateral one, the anterior band is somewhat narrow with the anterior margin straight, and the posterior deeply bi-sinuate, the second band is slanting from the suture to the outer margin, and expanding towards the sutural part is connected along it with another slanting supra-apical band reaching the outer margin, the anterior edge of the second band is broadly scooped laterally, the posterior edge is bi-dentate; both edges of the supra-apical band are nearly straight.

Length $15 \mathrm{~mm}$.; width $6 \mathrm{~mm}$.

Hab. Cape Colony (Worcester, Tulbagh, Paarl, Ceres, Stellenbosch, Namaqualand).

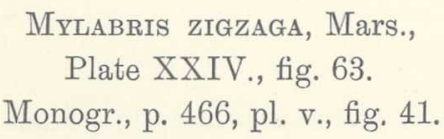

Black, clothed with a short, black pubescence, antennæ entirely black, the intermediate joints somewhat conical but not sharply acuminate inwardly, third joint one-third or more longer than the fourth; head and prothorax covered with nearly contiguous, somewhat deep punctures, the prothorax is well attenuated into a neck, and the median line is very plain; elytra with the black background covered with sub-contiguous deep punctures all very briefly setiferous, but very sparsely scattered on the pale yellow spots and bands; the base has a broad orange-red border, below this are three patches of which the two dorsal ones are ovate, the lateral extends along the margin; the ante-median band is very narrow, strongly zigzagged owing to the deep scooping of both edges; the posterior one consists of a transverse patch sending a narrow spur connected with an elongated supra-apical patch which is connected in the same manner with the other portion of the posterior band which abuts on the outer margin.

This very distinct South African species was captured by Professor H. W. W. Pearson, in German South-West Africa, feeding on the inflorescences of that extraordinary plant, Welvitschia mirabilis. It is also found on the Nara melon Acanthosycios horrida.

Length $17 \mathrm{~mm}$.; width $5 \frac{1}{2} \mathrm{~mm}$. 


\section{Mylabris dentata, Oliv., Plate XXIV., fig. 64.}

Encycl. Méth., viii., 1811, p. 97 ; Mars., Monogr., p. 496, pl. v., fig. 52. tortuosa, Erichs., Wiegm. Arch., 1843, i., p. 256.

Black, clothed on the head, prothorax, and under side with a very dense silky flavescent pubescence; antennæ black; head and prothorax very closely and finely punctate, the punctures simple; elytra with two distinct costules on each side and covered with deep, slightly uneven punctures of equal size on the yellow parts, and more rugose and slightly shagreened on the black intervals ; the pale yellow colour of the transverse bands has invaded the greatest part of the black background which is thus reduced to a sub-arcuate scutellary patch, a humeral spot and three very narrow, transverse, zigzagged bands reaching from side to side, the posterior one emitting a supra-outer marginal ramus ending in a small round patch situated at about the central part of the supra-apical part.

Length $14 \mathrm{~mm}$. ; width $5 \frac{1}{2} \mathrm{~mm}$.

This species seems to occur along the West Coast of Africa, from Senegambia to Damaraland. My examples are from Okahandja in Damaraland.

Mylabris basibicincta, Mars., Plate XXIV., fig. 65.

Monogr., p. 497, pl. v., fig. 53.

? lacerata, Péring., Trans. South Afric. Philos. Soc., iv., 1888, p. 130, pl. 3, fig. 11.

Intermediate in size and markings between $M$. dentata and Ceroctis groendali. From dentata it differs by the pubescence of the head, prothorax and under side, and the much more remote and deeper punctuation of the head and prothorax; the black background of the elytra is much more rugose, the yellow bands are also more broadly separated; they bear on each side a broad, basal pale yellow band reaching from the suture to the outer margin and the lower edge of which is bi-denticulate; this band includes a small humeral black spot; the ante-median band is not quite as broad as the basal, and is strongly bi-incised on each border; the postmedian one seems to consist of two coalesced patches, the broader of the two being adjacent to the suture, and the borders are thus deeply biincised; the apical band, which does not quite reach the suture and the outer margin, consists of two patches the outer of which is the smaller of the two, and is occasionally narrowly connected with the larger.

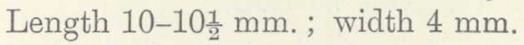

Hab. Cape Colony (Kenhardt, Beaufort West). 
My $M$. lacerata seems to differ very little from the typical $M$. basibicincta, except that the apical yellow band is divided into two. I have however identified Marseul's type from the description and figure only, and M. Lesne informs me that my $M$. lacerata is not represented in Marseul's collection.

South African Species which I have not seen, or been able to identify.

$\mathrm{A}^{2}$. Antennæ black.

$$
\begin{aligned}
& \text { Mrlabris trifolia, Mars., } \\
& \text { Plate XXIII., fig. } 60 . \\
& \text { Monogr., p. 461, pl. v., fig. } 39 .
\end{aligned}
$$

"Oblong, moderately wide and moderately convex, black, shiny, sparsely hairy, hairs black; head sub-quadrate, strongly inflated behind the sinuate, globose eyes, and densely punctate, frontal part moderately convex and slightly impressed on each side; antennæ slender; prothorax broad, vaguely punctate, the sides roundly dilated, coarctate and suddenly narrowed in front, reflexed at the base, sub-impressed in the centre; scutellum strigulose, rounded at apex; elytra vaguely punctulate, subparallel, marginate, the shoulders raised, rounded at apex, and having on each side an ante-median, narrow, sinuate, pale yellow transverse band, a basal outer marginal ovate macule, and close to the base another median macule; the posterior band is broader and dilated in the centre of the posterior border into a very distinct patch; this posterior band is blood-red.

Length $20 \mathrm{~mm}$; ; width $7 \mathrm{~mm}$.

Hab. Kaffraria."

Marseul places this species after $M$. lavaterce.

$$
\begin{aligned}
& \text { Mrlabris svakopina, Mars., } \\
& \text { Plate XXIV., fig. } 66 . \\
& \text { Monogr., p. } 477 \text {, pl. v., fig. } 46 .
\end{aligned}
$$

Oblong, sub-cylindrical, black, opaque above, hardly pubescent; head and prothorax deeply punctate; antennæ strongly clavate; elytra subparallel, closely rugose punctate, and having on each side a dorsal sub-basal yellow patch connected near the scutellary region and along the suture with a moderately broad transverse ante-median band, and an outer marginal narrower band reaching from the base to the said 
transverse band; past the middle is a narrower band interrupted in the centre and disconnected from the suture; this band is probably occasionally entire.

Length $10 \mathrm{~mm}$.

Hab. Damaraland (Svakop River).

Marseul states that this species cannot be mistaken for any other.

$A^{\mathrm{T}}$. Antennæ yellow with the two basal joints black.

\author{
Mylabris gamicola, Mars., \\ Plate XXIII., fig. 56. \\ Monogr., p. 436, pl. iv., fig. 23.
}

Elongated, sub-cylindrical, black, densely punctulate, clothed with a thick, silky yellow pubescence; antennæ long, very slender; prothorax sub-quadrate, rounded laterally, little narrowed in front, finely canaliculate in the centre; elytra with a basal dorsal elongate pale yellow band reaching to about one-third of the length and somewhat triangular at apex, at about the middle is a transverse strongly bi-sinuate band of the same colour and broadly disconnected from the suture, and in the posterior part a similar but narrower band; both these bands are connected along the outer margin by a broad band of similar colour running from the base.

Length $14 \mathrm{~mm}$.

Hab. N'Gamiland.

\author{
Mylabris Bicincta, Mars., \\ Plate XXIII., fig. 49. \\ Monogr., p. 521, pl. v., fig. 60.
}

Elongated, moderately convex, black, clothed with a silky silvery pubescence; head and prothorax densely punctate; antennæ moderately slender; prothorax broad, little convex, deeply impressed transversely past the anterior border; elytra densely rugosely punctulate and having on each side a slightly slanting dorsal basal band connected along the base with a humeral band running along the outer margin and connected there with an ante-median transverse somewhat narrow band reaching the suture, and very slightly sinuate; past the middle is a similar but narrower band, and a somewhat broader quite apical one; these bands are orange-yellow and densely punctate.

Length $13 \mathrm{~mm}$. ; width $4 \frac{1}{2} \mathrm{~mm}$.

Hab. N'Gamiland. 
Mylabris nativa, Voigts.,

Deutsch. Ent. Zeitsch., 1903, p. 107.

"Oblong, black, opaque; antennæ yellow with the two basal joints black, 3rd and 4th of equal size; palpi black; flavo maculate underneath; mentum flavescent at apex; head and prothorax coarsely and densely punctate, the punctures denser towards the middle and the sides of the former, both are clothed with black hairs, the head has a smooth space between the eyes and often a longitudinal more or less raised line; the prothorax is as broad as long, with the sides rounded, and is narrower in front, the dorsal part is transversely impressed in the centre and before the base and has in addition some more or less distinct, irregular impressions, from the base to the apex is a longitudinal smooth more or less raised line and a median impression slightly sulcate; elytra deeply and densely rugulose punctate, clothed with black villose hairs in the basal region, and with black, depressed hairs mixed with greyish ones on the rest of the surface, these have each four longitudinal raised lines; on each side are two small rounded flavous sub-equal basal macules, one dorsal, the other humeral, and situated between the gibbosity and the lateral margin, two transverse fasciæ, the one situated before the median part, broader towards the suture than towards the margin with the anterior border nearly straight, sub-undulate on the posterior, slightly oblique from the suture outwardly, the second situated past the middle, is nearly twice broader towards the suture than outwardly, moderately abruptly narrowed outwardly towards the second raised line, and undulate behind, these fasciæ are yellow, moderately shiny, nearly glabrous, more finely and more sparsely punctate with the punctures brownish, the posterior fascia is girded in front, and much more so behind with red with a vague tinge of black; under side punctulate, clothed with a black villosity; anterior femora and tibiæ with the inner part pilose, the hairs golden fulvous; posterior tarsi with the first joint red at the base; spurs of the hind tibiæ equal, red, flavous at apex.

Length $33 \mathrm{~mm}$.

Hab. Natal."

This species would seem to approximate the large examples of M. oculata, var. vulgaris.

\section{Gen. CEROCtis, Mars.,}

Plate XXIV., fig. 67.

Monogr. Abeille, vol. vii., 1870, p. 9.

The genus differs from Mylabris in the shape of the antennal joints which are strongly serrate inwardly, and even flabellate in the $\sigma$. All the species are African. 
$\mathrm{A}^{2}$. Elytra with transverse bands and spots.

B3. Antennæ black.

$\mathrm{C}^{2}$. Elytra with a dorsal and a lateral patch, both occasionally coalescent, and two transverse yellow or red bands, sometimes interrupted, no apical patch.

$D^{6}$. Basal and lateral patches always broadly separated from the anterior band, basal dorsal patch strongly lunulate.

Dorsal patch produced into a longitudinal lunule, the two bands broadly interrupted and reduced to two yellow patches connected with the suture, and two smaller, sub-triangular, outer marginal. Elytra strongly shagreened (pl. xxiv., fig. 68) $\quad$..

capensis

D5. Basal and lateral patches not always broadly separated from the anterior band; basal dorsal patch not lunulate.

The dorsal and lateral patches have invaded the whole base, forming a broad band coalescing with the anterior except for two non-obliterated triangular spots of the background; posterior moderately wide, anterior edge emarginate in the centre, posterior dentate there (pl. xxiv., fig. 69) korana.

The basal, dorsal, and lateral patches coalesce so as to form a basal band separated from the anterior transverse one (pl. xxiv., figs. 70, 71)

The basal dorsal and lateral patches are quite separated, and so are the anterior and posterior bands, which are each divided into two patches (pl. xxiv., fig. 72) .. ..

karroensis.

$\mathbf{C}^{\mathrm{x}}$. Elytra with a dorsal and a lateral patch, two transverse yellow or reddish bands either coalescing, often interrupted or pinched in the centre, and an apical patch or band.

D4. Basal, dorsal, and lateral patches and bands coalescing into a very broad band reaching past the median part.

Basal, dorsal, and lateral patches uniting with the anterior band, which in turn unites with the post median; a broad, sub-hamate red patch in the posterior part and a small black spot on the dorsal part at some distance from the base (pl. xxiv., fig. 73) $\quad . \quad \ldots r$..

$D^{3}$. Basal patch and lateral spot not invading the whole of the base.

Dorsal patch of elytra coalescing at the suture and connected alongside of it with the anterior narrow yellow band which is constricted in the centre, and is connected along the outer margin with the lateral basal 
patch; posterior band strongly bi-constricted, much narrower near the margin than near the suture, continued as a red band along the outer margin and coalescing at apex with a very broad, dark-red patch

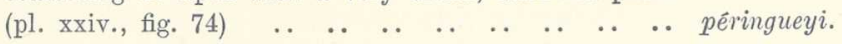

$D^{2}$. Basal patch of elytra not connected in the dorsal part with the anterior band.

A dorsal basal elongate red patch and a lateral one connected along the suture with a median, very little sinuate red band, post-median band similar in shape and colour, posterior patch filling the apex, and also red; pubescence flavescent (pl. xxiv., fig. 76) .. ..

Dorsal yellow or sub-orange-yellow basal patches ovate, reaching the suture; anterior and posterior bands strongly constricted in the centre, triangularly dilated towards the outer margin, but occasionally divided each into two patches, apical part invading nearly the whole apex, or crescent-shaped ; body shagreened (pl. xxiv.,

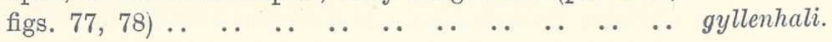

The same, but with the dorsal basal patches coalescing across the suture, apical patch reaching very short of the suture; body not shagreened (pl. xxiv., fig. 79) .. serricornis.

Base of elytra with a basal, yellowish, or yellowish red transverse band nearly equal in width to the anterior and posterior which are narrow, strongly bi-zigzagged, and expand narrowly along the outer margin; apical patch sub-transversely ovate, median but emitting a spur towards the outer margin (pl. xxiv., fig. 80) ..

Each elytron with four yellow, more or less rounded patches between the dorsal part and the suture, a humeral elongated yellow band connected with a submedian lateral patch, past the middle another marginal patch; these two marginal patches are occasionally connected with the two dorsal ones, or very narrow and broadly disconnected (pl. xxiv., figs. 81, 82, 83) ..

aliena.

Elytra each with four yellow dorsal spots set in a longitudinal row, and three marginal ones the basal of which is plainly elongated (pl. xxiv., fig. 84) $\quad$.. $\quad$.. $\quad$.. $\quad$..

blanda.

spuria.

$D^{x}$. Basal part of elytra with a broad yellow band connected more or less completely with the anterior one.

$B^{2}$. Antennæ reddish or yellow with the two basal joints black.

Dorsal patch of elytra coalescing along the suture with the anterior moderately bi-sinuate band, second band constricted in the centre, reduced thence to the margin by half its width, and with the lower edge bi-sinuate; apical part with two ovate, coalescing patches; bands and patches reddish; antennæ flabellate inwardly (pl. xxiv., fig. 75) 
$\mathrm{B}^{\mathrm{r}}$. Antennæ black with joints 3-6 flavescent.

Surface of elytra pale yellow but occasionally also orange-yellow; on each side are a supra-humeral black spot, three ante-median ones disposed transversely, two strongly sinuate dentate somewhat narrow black bands ; the apical angle is also black (pl. xxiv.,

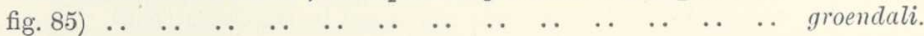

The same, but the humeral black spot and the three anterior ones are reduced to a mere dot; the posterior band is interrupted in the centre (pl. xxiv., fig. 86)..

var. extrema.

Basal part yellow for about one-third of the whole length, and with a humeral small patch and a juxta-sutural spot of the black background showing through; the post-median band is plainly sinuate, the apical one is transverse, and both are red (pl. xxiv., fig. 87)

$\mathrm{A}^{\mathrm{x}}$. Elytra with longitudinal bands and spots.

Elytra each with a longitudinal dorsal and a lateral yellow or orangeyellow band reaching from the base to past the middle, and two or three patches in the posterior part; upper side with a dense, very short silky pubescence :

Dorsal band reaching slightly past the middle, three distinct, round patches; tibiæ black (pl. xxiv., fig. 88)

Dorsal band reaching to four-fifths of the length, a posterior marginal transverse patch and a supra-apical one; tibiæ black

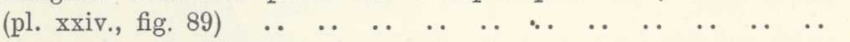

exclamationis.

Dorsal band reaching the supra-apical patch, or not; the posterior marginal patch small, slightly transverse ; femora and tibiæ flavous (pl. xxiv., fig. 90)

\section{Ceroctis capensis, Linn., Plate XXIV., fig. 68.}

Mus. Lud. Ulr., 1764, p. 104 ; Billb., Monogr., p. 37, pl. 4, fig. 11 ; Oliv., Entom., iii., 47, 12, 2, pl. 2, fig. 12; Mars., Monogr., p. 553, pl. v., fig. 66.

Black, clothed on the under side, head and prothorax with a dense, erect, black pubescence; antennæ black, the five apical joints with a somewhat silky sheen, inner part of the intermediate joints moderately sharply acuminate at the tip; head and prothorax very closely scrobiculate punctate, frontal part with a short median line, prothorax with no distinct one; elytra elongated, strongly shagreened and with the yellow patches or bands roughly and somewhat closely punctate; each bears a basal dorsal band curving outwardly into a lunule and reaching to about one-fifth of the length, and an elongated lateral band; at about the median part is a 
transverse patch connected with the suture and reaching to about the median part of the disk, and a similar but slightly longer one at a short distance from the apex; on the outer margin are two short patches situated each at an equal distance from the basal lunule and the anterior patch and from the anterior and posterior ones.

The dorsal part of the abdomen is pinkish red, and shows conspicuously when the insect flies, but in examples from the Northern Transvaal this part is black.

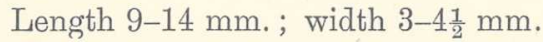

Hab. Cape Colony (Cape Town, Stellenbosch, Paarl, Ceres, Worcester, Malmesbury, Namaqualand, Kimberley, Mossel Bay, Knysna, Grahamstown, East London, Somerset West).

This species is generally found singly or in pairs, and its pattern very seldom varies. No varietal form has come to my notice.

\section{Ceroctis korana, Péring., Plate XXIV., fig. 69.}

Trans. S. Afric. Phil. Soc., iv., 1888, p. 130, pl. iii., fig. 9.

Black, clothed with a very short black pubescence, not very dense on the head and prothorax which are deeply but somewhat sparsely punctate, the punctures on the former are however closer on the epistome, and the frontal, smooth patch is plain; on the elytra the pale yellow parts are deeply and moderately closely scrobiculate punctate, but the muchreduced black background is very deeply and closely punctulate; the anterior part from the base to slightly past the middle is pale yellow with the exception of a triangular black patch situated at about one-fourth of the length, and the edge of this yellow part is slightly bi-sinuate; at an equal distance from the anterior yellow band and from the apex is a moderately broad band extending like the anterior one from side to side, and slightly scooped in the anterior border, the posterior is arcuate.

Length $12 \mathrm{~mm}$; width $4 \mathrm{~mm}$.

Hab. Cape Colony (Kenhardt).

Var. KORANELLA, Plate XXIV., figs. 70, 71.

Like the type in sculpture and vestiture, but on the elytra is a broad basal pale yellow patch which coalesces with the lateral (fig. 71) and even forms with it a broad transverse basal band (fig. 70); there is an ante-median transverse band reaching from side to side with both the 
edges sharply sinuate, and the post-median one is of the same size as the ante-median, and similarly scooped in the anterior edge.

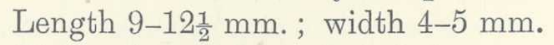

Hab. Cape Colony (Prieska).

Ceroctis karroensis, n. sp.,

Plate XXIV., fig. 72.

Black, moderately shiny, clothed on the head and prothorax with a moderately dense, appressed greyish flavescent pubescence which is very short on the elytra, but a little longer there in the posterior than in the anterior part; antennæ black, very sharply serrate; head and prothorax covered with unequal rugose, contiguous foveate punctures; head with a conspicuous median raised line; elytra closely shagreened and having on each side a row of three dorsal yellow patches equi-distant from the suture and the median dorsal part and three corresponding ones on the outer margin. It is probable that both the second and third dorsal and marginal patches do occasionally meet, as they are somewhat sinuose, whereas the first basal dorsal patch is quite round. Under side and legs moderately pubescent.

This species, of which I have seen only one example $(\delta)$, is allied to $M$. koranella, but the 5-7 joints ( $\delta$ ) are not so sharply serrate inwardly, and the two transverse bands of the elytra, if they united, would be much narrower than in $M$. koranella.

Length $9 \mathrm{~mm}$.; width $3 \mathrm{~mm}$.

Hab. Cape Colony (Beaufort West).

\section{Ceroctis gariepina, Péring.,} Plate XXIV., fig. 72.

Trans. S. Afric. Philos. Soc., iv., 1888, p. 130, pl. iii., fig. 10.

Black; antennæ black; head, prothorax, and under side clothed with a short, dense, greyish flavescent pubescence; prothorax closely and somewhat roughly shagreened; elytra moderately shagreened, but with the black background more coarsely punctate than the coloured part; on each elytron there extends a pale yellow very broad band reaching to past the median part from near the base, along which is a narrow border of the black background which descends also laterally below the humeral part; this yellow band encloses a small black dot situated at about one-quarter of the length, and is deeply scooped twice on the hind margin which is separated only by a narrow interval from a reddish elongated patch extending from close along the suture to about one-third of the width without reaching the apex, strongly constricted at about the 
median part and produced thence right to the outer margin into a much narrower transverse band.

This species, of which I saw only two partly mutilated examples, would seem to be very distinet from C. korana, although found in the same locality.

Length $12 \mathrm{~mm}$; ; width $5 \mathrm{~mm}$.

Hab. Cape Colony (Prieska).

Ceroctis péringueyi, Vogt., Plate XXIV., fig. 74.

Wien. Ent. Zeit., xx., 1901, p. 215.

C. distincta, Péring., Trans. S. Afric. Phil. Soc., iv., 1888, p. 131, pl. 3 (name preocc.).

Black, clothed with a short, black pubescence turning to sub-flavescent on the prothorax ; antennæ black ; head and prothorax covered with subcontiguous, somewhat deep, round punctures; elytra with the yellow part closely and evenly punctulate, the black part shagreened aciculate, the red part more roughly punctate than the yellow; on each side the broad basal dorsal patch is connected along the suture with the anterior trans. verse band which is narrow, slightly scooped in the anterior edge, and expands along the outer margin where it becomes one with the lateral dorsal patch, thus forming a marginal band; the posterior band is greatly constricted in the median part and narrowed thence to the outer margin where it is continued as a red band coalescing with the posterior part, which is wholly blood-red except for a narrow, apical black border.

Length $11 \mathrm{~mm}$. ; width $4 \mathrm{~mm}$.

Hab. Cape Colony (Kenhardt).

Ceroctis marshalli, Pic.,

Plate XXIV., fig. 75.

Rev. d'Entomol., xxii., 1903, p. 165.

C. mosambica, Pér., Ann. S. Afric. Mus., iii., 1904, p. 283.

Black, clothed with a flavescent pubescence with admixed fuscous hairs on the head and prothorax; antennæ rufous flavous with the two basal joints black, the intermediate joints from the sixth to the seventh are so sharply acuminate inwardly at apex as to be almost sub-flabellate; head and prothorax covered with deep, but small, nearly contiguous punctures, in the former there is no visible frontal patch, in the latter the central, discoidal impression reaches from the centre to the base; elytra elongated, the orange-red dorsal bands are very closely punctate, and the punctures on the black background are as closely punctate but slightly 
more shagreened; on each side the basal dorsal ovate patch coalesces along the suture with the broad anterior band which is moderately deeply sinuate, the lateral patch is elongated but does not reach the anterior band, the post-median is broad and sub-quadrate from the suture to the median part, narrowed thence to the outer margin by about onethird, and the hind border is narrowly but somewhat deeply incised at about the middle; close to the apex but reaching neither the margin nor the suture are two elongate ovate patches coalescing at about their median respective part.

Length $24 \mathrm{~mm}$; width $8 \mathrm{~mm}$.

Hab. Southern Rhodesia (Salisbury); Mozambique (Rikatla, Maputa River).

This species is easily recognised from among the other South African Ceroctis by its sub-flabellate antennæ.

\section{Ceroctis blanda, Pér., Plate XXIV., fig. 76.}

Trans. S. Afric. Phil. Soc., vi., 1892, p. 64.

Black, clothed with a dense flavescent, sub-silky pubescence very noticeable on the elytra; antennæ black, the intermediate joints strongly aculeate flabellate in the inner side in the male, serrate only in the female; head and prothorax covered with deep punctures separated by a narrow, somewhat irregularly raised wall, and coalescing in some places, especially on the frontal part; black background of elytra finely shagreened, the bands and patches are red and covered with deep, contiguous, moderately small punctures, the basal dorsal patch is more in the shape of a longitudinal band reaching to one-fifth of the length, there is a lateral somewhat narrow band which rounds the shoulder, coalesces narrowly there with the dorsal band, and is produced downwards along the margin as far as the anterior transverse band which is of moderate width and only slightly bisinuate on each border, the post-median band is of the same width as the anterior, and the hind border is also slightly bi-sinuate, the posterior patch fills the whole apical part.

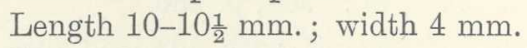

Hab. Ovampoland.

$$
\begin{gathered}
\text { Ceroctis gyllenhali, Billb., } \\
\text { Plate XXIV., figs. } 77,78 .
\end{gathered}
$$

Monogr., p. 21, pl. 2, figs. 17, 18; Mars., Monogr., p. 550, pl. v., fig. 64. variabilis, Oliv., Entom., iii., 47, p. 10, pl. 2, fig. $14 a$.

Black, clothed on the under side, head and prothorax with a dense, black, erect pubescence, antennæ totally black, the intermediate joints 
strongly acuminate inwardly; head and prothorax covered with deep, but small, uneven, rugose, contiguous punctures; elytra elongated, parallel, very scabrose on the black background, less so on the yellow, or orangeyellow patches or bands, owing to the punctures, which although scabrose, are less closely set, on each side are (type) a basal, dorsal, round, moderately large or large patch and a lateral, elongated one, two in the anterior part, two in the post-median, the lateral being smaller than the juxta-sutural, which does not reach quite the suture, and one apical (pl. iii., fig. 77); this typical form is however the rarest; in most examples the two ante-median and post-median patches coalesce near the middle of the disk and form thus two continuous bands strangulated in the centre (pl. iii., fig. 78), or these two bands are completely united and their anterior edges are bi- and the posterior edges tri-dentate, the apical patch is arcuate as if it consisted of two coalesced patches.

It is not uncommon to meet with examples in which the posterior band and patch are red; occasionally all the patches are red or deep orange-red.

Length 11-17 mm.; width $3 \frac{3}{4}-6 \mathrm{~mm}$.

Hab. Cape Colony (Cape Town, Stellenbosch, Paarl, Worcester).

\section{Ceroctis serricornis, Gerst.,} Plate XXIV., fig. 79.

Monatsb. Berl. Acad., 1854, p. 694 ; Peter's Reis. n. Mos., 1862, p. 300, pl. 18, fig. 1 ; Mars., Monogr., p. 548, pl. 5, fig. 63.

This species is so closely allied in general appearance and markings of the elytra to $C$. gyllenhali (large development) that it might easily be mistaken for it; but it differs in the following points: the pectination of the antennal joints is not so long; the claws are black or fuscous instead of being yellow; the head and prothorax are slightly roughly punctate but not shagreened, and the sculpture of the elytra consists of round, simple, moderately deep punctures, instead of a scabrose surface; the basal and lateral round yellow patches are similar in both species, but the anterior band is only slightly constricted in the centre, the post-median one is plainly separated, forming thus two sub-transverse patches separated by a narrow line, the apical patch is transversely elongate ovate.

In the type, apud Gerst., the dorsal round patch is elongated near the suture towards the anterior band, and the lateral is continued as a marginal band uniting there the two transverse bands.

Length $18 \mathrm{~mm}$. ; width $6 \mathrm{~mm}$.

Hab. Mozambique (Rikatla). 
Ceroctis spuria, Făhr., Plate XXIV., fig. 80.

Öfv. Vet. Ak. Forhdl., 1870, p. 344 ; Mars., Monogr., p. 500, pl. v., fig. 55.

C. vexator, Péring., Ann. S. Afric. Mus., iii., 1904, p. 284.

Black, clothed with a short, appressed flavescent pubescence on the under and upper sides; antennæ black; head and prothorax very deeply sub-scrobiculate punctate, frontal line distinct or not; elytra without any traces of costules, very closely punctate shagreened, the patches and bands are yellow with a more or less pronounced orange-yellow tinge, on each side are three transverse bands, a basal with a bi-sinuate hind border, an ante-median deeply bi-sinuate in the anterior border and tri-sinuate in the posterior, a post-median one tri-denticulate on each border, and a supraapical patch emitting a short spur towards the outer margin, all the three bands are continued downwards for a short distance along the outer margin, and the basal band is even connected there with the ante-median band. Făhrœus mentions a variety in which the basal band does not quite reach the humeral part, and another where this basal band is dilated inwardly, and becomes connected with the intermediate band towards the sutural part. This goes to show that the disposition of the bands is very variable.

Length $11 \mathrm{~mm}$; width $4 \frac{1}{2} \mathrm{~mm}$.

Hab. Transvaal (Pietersburg).

Ceroctis aliena, Pér., Plate XXIV., figs. 81, 82, 83.

Trans. S. Afric. Philos. Soc., vi., 1892, p. 64.

Black, clothed on the head and prothorax and on the under side with a dense flavescent silky pubescence; antennæ black; head and prothorax covered with rugose, nearly confluent punctures, the median sulcus of the latter part is very well marked; elytra sub-foveate shagreened in the anterior part, more distinctly and more closely shagreened in the posterior, and having on each side, but only in the large development, two somewhat distinct longitudinal costules in the anterior part only; on each elytron are four equi-distant, more or less quadrate, or rounded pale yellow or orange yellow patches disposed lengthways between the median dorsal part and the suture, and disconnected from the latter; along the outer margin is an elongated band running from the humeral part and dilated triangularly opposite the second dorsal patch, where it ends; lower down, opposite to the third dorsal one, is another patch absolutely similar in shape (fig. 81); in the first varietal form (fig. 82) the basal patch nearly coalesces with the 
lateral band, the triangular point of which unites also with the second juxtasutural spot forming thus a somewhat zigzagged band, the two post-median spots are no longer rounded, and they approximate closely to each other; in fig. 83 , which is really the type, the four dorsal patches are rather jagged and broadly separated from the much-reduced lateral band and spot.

Length 9-14 mm.; width 4-6 mm.

Hab. Transvaal (Pietersburg), Damaraland (Walfish Bay), Ovampoland.

\section{Ceroctis bohemani, Făhr., Plate XXIV., fig. 84.}

Öfv. Vet. Ak. Forhdl., 1870, p. 345; Mars., Monogr., p. 558, pl. 5, fig. 69.

Black, clothed with a short, appressed greyish white silky pubescence; antennæ black, joints strongly serrate inwardly, femora rufescent from the base to three-fourths of the length; head and prothorax very closely punctate, the punctures fine and round, but wider and more scattered on the frontal part; elytra finely shagreened and with the two dorsal lines well marked, on each side are four superposed juxta-sutural bright yellow, more or less ovate patches, a lateral longitudinal short band at the shoulder, and two small patches on the outer margin, the one anterior, the other post-median.

Length $13 \mathrm{~mm}$; ; width $5 \mathrm{~mm}$.

Hab. Transvaal (Pietersburg, Waterburg, Rustenburg, Pretoria, Klerksdorp), Natal (Eshowe), Southern Rhodesia (Bulawayo, Victoria Falls, Salisbury).

\section{Ceroctis groendali, Billb., Plate XXIV., fig. 85.}

Monogr., p. 30, pl. iii., figs. 17, 18 ; Mars., Monogr., p. 556, pl. 5, fig. 68.

Black, covered with a long, black and greyish, and very dense pubescence on the under side, the head and prothorax; antennæ black, the intermediate joints serrate; head and prothorax very closely and somewhat roughly punctured, frontal smooth mark distinct; elytra covered with deep, subcontiguous punctures divided by a raised wall imparting to them a coriaceous shagreened appearance; the pale yellow bands have invaded the greatest part of the surface, and the black background is thus reduced to a small humeral spot, three more disposed transversely in the anterior part, a median and a posterior strongly zigzagged narrow band, the latter expanding towards the outer margin which neither band reaches, and a small sutural apical dot. 


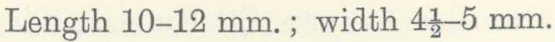

Hab. Cape Colony (Port Elizabeth, Grahamstown, East London), the whole of Orange River Colony, Natal, and the Transvaal.

Var. eXtrema, Plate XXIV., fig. 86.

Same as the type, but the humeral and the three anterior black spots are reduced to a mere dot, the median and posterior bands reach the suture, and the posterior is occasionally interrupted in the centre.

Length 12-16 mm.; width 5-5 $\frac{1}{2} \mathrm{~mm}$.

$H a b$. The eastern and northern part of the Cape Colony; the whole of Orange River Colony, Natal, Transvaal.

\section{Ceroctis quadrifasciata, Thunb.,} Plate XXIV., fig. 87.

Dissert. Nov. Insect. Spec., vi., p. 115, fig. 18; Billb., Monogr., p. 19, pl. ii., figs. 4-8.

bipunctata, Billb., loc. cit., p. 31, pl. 4, fig. 1; Mars., Monogr., p. 551, pl. v., fig. 65 .

Black, clothed with a dense, moderately short black pubescence; antennæ black, joints moderately sharply serrate; head and prothorax covered with small, smooth, somewhat shallow contiguous punctures, the former with a very distinct frontal line; elytra with a broad basal pale yellow band and two narrower orange-red ones, the black background is closely shagreened, the yellow and red bands scrobiculate, and the two dorsal costules are strong, the basal yellow band extends from the base to two-fifths of the length, and encloses a small dorsal black spot and a subhumeral, small black patch, the hind border of this band is slightly scooped laterally, the second band is less than half the width of the anterior, and uni-sinuate on each border, the posterior is supra-apical, somewhat narrower than the second, and reaches from suture to margin.

Length 14-15 mm. ; width $5 \frac{1}{4} \mathrm{~mm}$.

Hab. Cape Colony (Namaqualand).

The figures given by Billberg (loc. cit. supra) do not agree with this species, but with varieties of C. gyllenhali, with which, however, C. quadrifasciata is so closely allied that it might be considered as - a variety only were it not for its restricted habitat and its constant pattern. 


\section{Ceroctis trifurca, Gerst., Plate XXIV., fig. 88.}

Monatsb. Berl. Acad., 1854, p. 694; Peter's Reis., 1862, p. 298; Mars., Monogr., p. 204, pl. v., fig. 74.

ruficrus, Gerst., loc. cit., p. 695; Peter's Reis., p. 301.

Elongated, parallel, black, covered with a fine, appressed sub-flavescent silky pubescence; antennæ black, intermediate joints almost flabellate: head and prothorax very closely punctate, the punctures slightly rugose; elytra aciculate shagreened, the yellow bands and spots deeply punctate, each one with a flavous narrow dorsal longitudinal band reaching from the base to the median part, or slightly past that point; at about an equal distance from the end of that band and the apex is a round patch, and another at the apex itself, along the outer margin runs a similar band beginning at the basal part of the shoulder and reaching the middle, and at a short distance from it a small patch set opposite to the post-median dorsal one and a little less rounded than the latter; legs black, but occasionally flavescent (ruficrus).

Length $10 \frac{1}{2} \mathrm{~mm}$; ; width $4 \mathrm{~mm}$.

Hab. Mozambique (Beira), Southern Rhodesia (Plumtree). Occurs also in German East Africa.

In two examples of C. trifurca, kindly sent me by Professor H. Kolbe, compared to the type, the longitudinal dorsal band coalesces with the post-median dorsal round spot.

Ceroctis exclamationis, Mars.,

Plate XXIV., fig. 89.

Monogr., p. 563, pl. v., fig. 72.

Var. bi-vittata, Mars., Monogr., p. 560, pl. v., fig. 71.

Similar to M. trifurca, Gerst., the sculpture and the vestiture are the same, but the elytral dorsal band reaches from the base to four-fifths of the length, the round post-median patch being completely absorbed by it, and at an equal distance from the end of the dorsal line and of the apex is an elongate ovate patch, the lateral marginal band runs from the base of the shoulder to somewhat past the median part, and at some distance from it is a transverse patch reaching from the margin to a little more than onethird of the width. The intermediate joints of the black antennæ are as strongly serrate flabellate as in M. trifurca, and the elytral bands and patches are more orange yellow; legs black. C. bi-vittata seems to be a variety in which the dorsal band coalesces narrowly with the supra-apical patch; and the lateral one is nearly as long as the dorsal.

Length 11-12 mm.; width $5 \mathrm{~mm}$.

Hab. Southern Rhodesia (Salisbury). 


\section{Ceroctis phalerata, Erichs., Plate XXIV., fig. 90.}

Wiegm. Arch., 1843, p. 256 ; Mars., Monogr., p. 563, pl. v., fig. 73.

Greatly resembles the two preceding species, but is distinguished by the shorter, more appressed sub-flavescent pubescence which is also not silky, and is considerably denser on the elytra; the legs, tarsi and knees excepted, are red; the colour of the bands and patches on the elytra is orange yellow, on each elytron the dorsal band reaches from the base to three-fourths of the length, and at an equal distance from the end of this band and of the apex is a sub-transverse patch, the lateral marginal band reaches to two-thirds of the length, and close to it is a short, sub-transverse marginal patch. In all my examples the dorsal band reaches nearer to the supra-apical spot than in Marseul's figure, loc. cit.

Length $10 \frac{1}{2} \mathrm{~mm}$; width $4 \frac{1}{2} \mathrm{~mm}$.

Hab. Cape Colony (Prieska), Transvaal (Pretoria, Potchefstroom), Orange River Colony (Parys), Damaraland (Okahandja), Ovampoland.

\section{Gen. MIMESTHES, Mars.,$$
\text { Plate XXIV., fig. } 133 .
$$$$
\text { Monogr., 1872, p. } 207 .
$$

The only species included in this genus differs from Mylabris, Ceroctis, Decatoma, Coryna, \&c., by the depressed form of the elytra which are sub-transversely truncate behind and with the inner angle not rounded; the prothorax is more transverse, and very little attenuated in front; the basal joint of all the tarsi is very long, even in the anterior legs where it is as long as the two following taken together. The antennæ are 11-jointed, but the club consists of three joints so closely set, although the sutures are quite distinct, as to resemble nearly that of the genus Coryna.

\section{Mimesthes maculicollis, Mars., Plate XXIV., figs. 134, 135, 136.$$
\text { Monogr., p. 207, pl. ii., fig. } 76 .
$$

Black, covered with a moderately dense, fairly long greyish black pubescence, antennæ black; head closely and roughly punctulate; prothorax parallel, almost as broad as long, covered with moderately deep, round punctures which are scattered in the anterior part, and are more closely set in the posterior; they have on each side of the anterior part a rufescent yellow patch separated from each other by a narrow discoidal band; elytra parallel, depressed, very briefly pubescent, finely shagreened on the black background, very closely punctate on the yellow 
bands and patches; on each side there is a basal macule occupying nearly the whole dorsal part, and a smaller lateral one; the anterior band is produced triangularly forward in the centre, the space of the hind border being correspondingly scooped; the post-median band somewhat resembles the anterior, but is not so sharply dentate in the anterior border, and along the apex is a transverse, elongated patch reaching neither suture nor outer margin.

Length $7 \frac{1}{2}-13 \frac{1}{2} \mathrm{~mm}$. ; width $3-4 \frac{1}{2} \mathrm{~mm}$.

Var. $a$. The basal dorsal macule coalesces close to the suture with the dorsal part of the anterior band, leaving a small sub-median spot of the background showing.

Var. $b$. The yellowish red prothoracic band has invaded the whole anterior part, and the elytra are black with the exception of a small apical yellowish red transverse patch.

Hab. Cape Colony (Namaqualand, Carnarvon, Prieska).

Gen. DECATOMA, Cast., Plate XXIV., fig. 91.

Hist. Nat. d. Ins., ii., 1840, p. 268.

Antennæ ten-jointed, last joint dilated, more or less ovoid.

\section{Key to the Species.}

$\mathrm{A}^{\mathrm{x}}$. Antennæ with the five basal joints black, the others yellow.

Elytra with a dorsal basal band, patch or lunule, a lateral one, and two transverse, strongly sinuate or sinuate dentate bands.

A longitudinal yellow band from the base to short of the median part, a sinuate median patch, and a rounded supra-apical one in the dorsal part, an elongated humeral and two hamate ones along the outer margin (pl. xxiv., fig. 92)

catenata.

An ovate rounded basal dorsal patch and a lateral spot, two bands of nearly equal size, the former with both margins broadly scooped, the latter scooped in the anterior margin and with the lower sinuate (pl. xxiv., figs. 93, 94). ..

An arcuate basal dorsal patch the apex of which reaches the suture and is slightly connected there with an anterior band considerably narrowed from the middle to the suture, the hind margin of the narrowed part strongly bi-incised, posterior band similar in shape and size, but with the anterior margin also bi-incised (pl. xxiv., $\begin{array}{llllllllllllll}\text { fig. 95) } & . & . & . & \ldots & \ldots & . & . & . & . & \ldots & . & . & .\end{array}$ lunata.

Basal lunule and the two transverse bands plainly separated, the two bands narrow, each bi-sinuate dentate on both edges (pl. xxiv.,

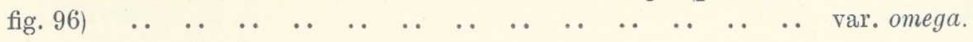


Basal lunule thickened inwardly at apex, the two transverse bands broad close to the suture, very narrowed and strongly sinuate from near the median part to the outer margin (pl. xxiv., fig. 97).. . .

var. umtalina.

Basal lunule small, little arcuate, the two bands very broad, of equal width, coalescing along the outer margin and separated on the dorsal part by a very narrow band of the background culminating into a small patch (pl. xxiv., fig. 98) $\quad$.

Basal lunule sub-longitudinal, thickened on the posterior part and reaching one-third of the length, anterior band acuminate behind and reaching the second one; both the bands are narrowed laterally and the edges deeply sinuate dentate (pl. xxiv., fig. 99) $\ldots$.. $\quad .$. var. salisburiana.

Basal lunule coalescing in the centre of the disk with the anterior band which is separated from the posterior by a moderately wide space; shape of the bands as on the previous variety (pl. xxiv., $\begin{array}{llllllllllllll}\text { fig. 100) } & . . & . . & . . & . . & . & . . & . . & . & . . & . . & . . & . . & . .\end{array}$ var. digressa.

Elytra suffused with yellow from the base to the median part except for a square, small black patch on the scutellary region, hind margin dentate along the suture, bi-sinuate laterally, hind band strongly bi-sinuate, narrow, and tapering towards the outer

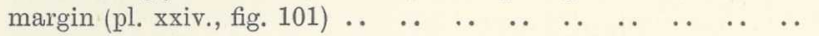

var. rhodesiana.

The same, but at about one-third of the length there is a small median black dot, and the posterior band similar in shape to that of rhodesiana is broader and connected by a narrow line with the sub-median part of long anterior yellow patch (pl. xxiv., fig. 102)

var. lydenburgia.

Basal lunule slanting, not crescent-shape; anterior band very narrow, of nearly equal width, narrowly interrupted above the outer margin, posterior band very slender, interrupted past the median part (pl. xxiv., fig. 103) $\quad$.

Basal part of elytra with a long, yellow lunule, two narrow bisinuose yellow bands, the posterior slightly wider than the anterior (pl. xxiv., fig. 104) .. sobrina.

$\mathrm{A}^{2}$. Antennæ black, with the joints 3-6 flavescent.

Surface of elytra pale yellow, on each side two rows of three black spots disposed diagonally, a supra-apical series of two spots, and the edge of the apical part black (pl. xxiv., fig. 105) $\quad \ldots \quad \ldots \quad$..

Basal joint of elytra with a yellow dorsal arcuate patch reaching the suture, the two bands very narrow, both sinuate dentate, the posterior more strongly than the anterior (pl. xxiv., fig. 106) ..

undata.

Basal lunule invading the median anterior part and coalescing there with the median band leaving only two small black spots; posterior band narrow, with both edges strongly bi-sinuate (pl. xxiv., fig. 107) .. stellenboschiana.

Anterior and posterior bands with both edges sharply tri-sinuate (pl. xxiv., fig. 108) $\quad$. 
Basal lunule coalescing with the anterior band which is broadly united also with the posterior along the suture, and narrowly along the outer margin, or with the basal dorsal patch and the two bands free but dentate and coalescing along the margin (pl. xxiv., figs. 109, 110) $\ldots$..

Basal patch slanting towards the suture, not connected with the anterior band which is broadly scooped in the fore border, the hind one being strongly tri-dentate, posterior band also scooped in front, the hind border produced in the centre in a rounded lobe beyond the edge of the band (pl. xxiv., fig. 111) $\quad \ldots \quad$.

Basal patch round, not coalescing with the anterior band, both edges of which are sinuate, posterior band slightly broader than the anterior with the fore border deeply scooped in the centre, posterior border bi-incised (pl. xxiv., fig. 112) $\ldots$..

Basal patch sub-ovate, anterior and posterior bands so broadly interrupted in the centre as to resemble four yellow patches (pl. xxiv., fig. 113) $\quad \ldots$. .

All the yellow patches reduced to a mere dot (pl. xxiv., fig. 114) .. var. namaqua.

Elytra each with a basal dorsal and a lateral patch or spot, two sinuate transverse bands and an apical patch.

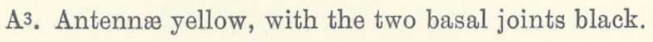

Basal dorsal and lateral patches broad, rounded, the two bands broad, hind margin of the anterior, and both edges of the post median plainly bi-sinuate, apical patch ovate, red, the other

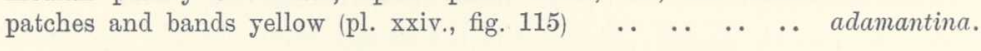

A4. Antennæ black.

Basal dorsal patch comma-shape or sub-quadrate, the two transverse bands strongly zigzagged, posterior band slanting, sinuate dentate, occasionally united with the apical patch by a narrow spur (pl. xxiv., figs. 116, 117) $\quad$.

\section{Decatoma catenata, Gerst.,} Plate XXIV., fig. 92.

Monatsb. Berl. Akad., 1854, p. 695 ; Peter's Reis., p. 302, pl. xviii., fig. 3 ; Mars., Monogr., p. 58, pl. vi., fig. 13.

Black, clothed with a dense flavescent silky pubescence; the five basal antennal joints are black, the other five rufescent flavous; the bands and patches on the elytra are moderately pale yellow; head and prothorax covered with very closely set, well-nigh contiguous, slightly rugose punctures, frontal part with a central line and smooth patch; elytra parallel, the black background and also the patches and bands covered with deep, sub-contiguous, slightly uneven punctures the intervals of which are too regularly raised to give the elytra the appearance of being shagreened, on 
each side there is a basal dorsal band gradually slanting towards the suture and reaching to a third of the length, an elongated lateral one, and a sinuate median patch reaching from the suture to the median dorsal part; above this patch is a somewhat elongated, more or less triangular, or hamate marginal one the inner point of which does probably coalesce with the outer part of the median dorsal in some examples; in the posterior part and under the median patch is a sub-transverse rounded one, and a lateral broader than the one above it, also hamate, very nearly connected with the discoidal, and prolonged as a narrow band along the outer margin.

Length $14-17 \mathrm{~mm}$; width $5 \frac{1}{2}-6 \frac{1}{4} \mathrm{~mm}$.

Hab. Southern Rhodesia (Victoria Falls); Mozambique (Beira).

\author{
Decatoma cafra, Mars., \\ Plate XXIV., fig. 93. \\ Monogr., p. 587, pl. 6, fig. 12.
}

africana, Billb., Monogr., p. 57, pl. 6, fig. 8 .

Black, covered with a black and greyish pubescence, dense underneath and on the head and prothorax, moderately so on the elytra, near the apex of which is a silky, whitish flavescent patch, the five basal antennal joints black, the other five yellowish rufescent; head and prothorax covered with almost contiguous, sub-rugose punctures, frontal part with a more or less distinct smooth patch; elytra plainly shagreened, bands and patches pale yellow, on each side are a sub-elongate ovate basal dorsal patch and a shorter elongate lateral one, a transverse moderately broad band consisting of two patches united in the centre of the disk by a band narrower than the patches by one-half, and a post-median band formed in the same manner, and having thus the appearance of being deeply scooped in the anterior and posterior borders.

\title{
Var. DEREPTA.
}

The elytra bear each three superposed patches set between the suture and the median dorsal part, and three other, of nearly the same size, set along the suture opposite the dorsal three. The difference in the shape of the markings is simply due to the obliteration of the two transverse spurs connecting the dorsal patches as in the type form.* This variety is from Clanwilliam, Cape Colony.

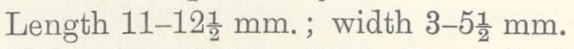

Hab. Cape Colony (Cape Town, Stellenbosch, Paarl, Worcester).

* The livery of this rare varietal form is quite similar to that of Coryna lugens (pl. xxiv., fig. 123), which, however, does not belong to the same genus. 


\title{
Var. ноттелтота, Plate XXIV., fig. 94.
}

The livery of this variety closely resembles that of $D$. africana, but the antennæ of the latter are wholly black.

\section{Decatoma lunata, Pall., Plate XXIV., fig. 95.}

Icon., p. 79, pl. 79, pl. E., fig. $5 a b$; Thunb., Diss. Nov. Ins. Spec., vi., p. 3, fig. 15 ; Billb., Monogr., p. 55, pl. 6, fig. 4 ; Mars., Monogr., p. 583, pl, 6, fig. 10.

americana, Herbst., Füss. Arch., v., p. 146, pl. 30, fig. 5a.

cichorii, Wulf., Ins. Cap., p. 17, pl. i., fig. 3; Billb., Monogr., p. 55, pl. vi., figs. 6,7 .

Type: Black, clothed with dense long black hairs; the five basal antennal joints black, the others yellow, patches and bands of the elytra pale yellow; head and prothorax covered with fine, closely set, round, smooth punctures; elytra somewhat ampliated in the posterior part, covered with closely set moderately deep punctures with sub-rugose walls, on each side are a dorsal basal areuate lunule reaching the suture, and a narrow elongated lateral patch, a nearly median transverse band narrowed by nearly one-half from the median dorsal part to the outer margin and with the lower edge bi-incised, and a post-median as broad as the anterior from the suture to the middle, narrowed thence to the margin, with the upper edge bi-sinuate, and the lower bi-incised, the outer incision being the deeper of the two; this band is often connected narrowly along the suture with the anterior; the pubescence is black on the black background, and flavescent on the yellow patches and bands, but in the centre of the apical black ground is a patch of flavescent hairs.

Length $12-17 \mathrm{~mm}$; width $14 \frac{1}{2}-6 \frac{1}{2} \mathrm{~mm}$.

Hab. Cape Colony (Cape Town, Stellenbosch, Paarl, Ceres, Worcester, Malmesbury, Knysna, Mossel Bay).

\author{
Var. OMEGA, Mars., \\ Plate XXIV., fig. 96.$$
\text { Monogr., p. 585, pl. 6, fig. } 11 .
$$

Differs from the type in the pubescence being flavescent on the head and prothorax ; on the elytra the dorsal arcuate lunule and the two transverse bands are broadly separated from each other, the inner part of the two bands is not so broad as in the type form, and the outer part has the two edges much more deeply incised.

Length 13-18 mm.; width 6-7 mm.

Hab. Everywhere in Natal and in the Transvaal. 


\author{
Var. umtalina, \\ Plate XXIV., fig. 97.
}

Size, sculpture, and vestiture of the variety omega, but the basal dorsal arcuate lunule extends further down and thickens towards the suture, the median band is strongly slanting from the outer margin towards the suture, and is produced there into an elongated patch the outer angle of which reaches the posterior band, and is strongly narrowed and bi-dentate from the median dorsal part to the margin; the posterior band is as in omega.

Length $16 \mathrm{~mm}$. ; width $8 \mathrm{~mm}$.

Hab. Southern Rhodesia (Umtali).

\title{
Var. Disputabilis, Plate XXIV., fig. 98.
}

Sculpture and vestiture of the other varieties; on the elytra the dorsal lunule is short and normally arcuate, the lateral patch is elongated into a short band, the anterior band is broad, the width being equal to about onefourth of the whole length, and it is separated from the equally broad posterior band by a narrow strip of the black background, but it is connected laterally for a quarter of the width with the posterior band the hind margin of which is briefly, not deeply sinuate.

Length $22 \mathrm{~mm}$.; width $9 \mathrm{~mm}$.

Hab. Natal (Newcastle).

\section{Var. SALISBURIANA, \\ Plate XXIV., fig. 99.}

Sculpture and vestiture of the preceding species; on the elytra the basal dorsal lune is prolonged into a hamate band reaching nearly to onethird of the whole length, and the lateral patch into a narrow band reaching the anterior transverse band, each border of which is strongly bi-sinuate, the hind one forming a short sub-median spur narrowly connected with the posterior band which is narrowed from the middle to the outer margin, and the fore border of which is scooped in the centre, and the hind one is bi-incised.

Length $14 \mathrm{~mm}$.; width $5 \mathrm{~mm}$.

Hab. Southern Rhodesia (Salisbury).

$$
\begin{gathered}
\text { Var. DIGResSA, } \\
\text { Plate XXIV., fig. } 100 .
\end{gathered}
$$

Like the variety salisburiana, but the apical part of the basal dorsal lunule is produced below the scutellary region into an elongated band 
coalescing from the suture to the centre of the disk with the broader part of the anterior band, but leaving exposed along the suture a sub-triangular patch of the background; the anterior band is shaped as in salisburiana, but very nearly connected behind with the posterior the shape of which is similar to that of the variety above-mentioned, but a little wider towards the margin.

Length $15 \mathrm{~mm}$.; width $5 \mathrm{~mm}$.

Hab. Southern Rhodesia (Salisbury).

\title{
Var. RHODESIANA, Plate XXIV., fig. 101.
}

Sculpture and vestiture of the preceding varieties; on each elytron the basal dorsal lunule has invaded the whole basal part except for a small quadrate black patch below the scutellum, and has become entirely connected with the anterior band suffusing thus with yellow the anterior half, the hind margin of that yellow suffusion emits a short spur along the suture, and is bi-denticulate from the centre to the outer margin, the posterior band is narrow and greatly attenuated and deeply bi-incised on each border from the centre to the outer margin.

Length $13 \frac{1}{2} \mathrm{~mm}$.; width $6 \mathrm{~mm}$.

Hab. Southern Rhodesia (Umtali).

\section{Var. LYDENBURGIA, Plate XXIV., fig. 102.}

In this variety the basal dorsal lunule has also invaded the whole anterior part, but there is a median dorsal small spot of the background showing at about one-third of the length, and the spur emitted near the suture is very narrowly connected at a short distance from it with the posterior band the shape of which is similar to that of the variety rhodesiana, but is wider.

Length $17 \mathrm{~mm}$; ; width $7 \mathrm{~mm}$.

Hab. Transvaal (Lydenburg).

\author{
Var. JOHANNIS, \\ Plate XXIV., fig. 103.
}

Very distinct from all the varieties of $D$. lunata. The pubescence is black, as in the type form, and there is also no silky flavescent patch of hairs above the apex of the elytra; the sculpture is, however, identical. The basal dorsal lunule is slightly elongate arcuate but does not reach the suture; the anterior band is of equal width, but very narrow and narrowly interrupted above the outer margin, the hind border is more sinuate 
towards the median part than the anterior, which is nearly straight, the supra-marginal patch is, however, broader than the uninterrupted part of the band; the posterior band which does not begin at the very suture is still narrower than the anterior, and more broadly interrupted past the centre.

Length $19 \mathrm{~mm}$; width $7 \frac{1}{2} \mathrm{~mm}$.

Hab. Transvaal (Johannesburg).

\section{Decatoma sobrina, n. sp., Plate XXIV., fig. 104.}

Black, covered with a dense sub-flavescent pubescence; the five basal antennal joints are black, the others yellow; on the elytra the lunules and bands are yellow; head and prothorax closely, and only moderately, unevenly punctured; frontal part without any distinct longitudinal smooth line; elytra very closely punctate, sub-shagreened; they have on each side an elongated arcuate lunule beginning in the basal dorsal part, but with the curved part not quite connected with the suture, an elongated lateral patch, a very narrow sub-median transverse band deeply and broadly bi-sinuated on either border, and occasionally slightly interrupted in the centre, and a somewhat broader post-median band also broadly sinuated on either border, but with the part extending from the suture to the median dorsal part broader than in the anterior; the flavescent pubescent patch on the hind part of the elytra is also fairly distinct.

Length $9 \mathrm{~mm}$. ; width $3 \frac{1}{2} \mathrm{~mm}$.

Hab. Natal (Howick).

Decatoma transvaalica, Pér.,

Plate XXIV., fig. 105.

Ann. S. Afric. Mus., vol. iii., 1904, p. 284.

Black, with the head, prothorax, scutellum, abdomen, pectus, and legs clothed with a very dense, silky, yellowish pubescence; antennæ black with the exception of the 3-5 joints which are red or reddish flavescent; head somewhat broadly and deeply punctate, and with a faint, short, smooth line abutting on the transverse impression of the epistome; prothorax of the normal shape, covered with contiguous, deep, not broad, but slightly scrobiculate punctures, and having a very slight median impression; scutellum closely punctate; elytra sub-cylindrical, hardly wider across the posterior part than at the base, finely shagreened, bi-costulate on each side in the dorsal part, clothed with an appressed, brief, slightly flavescent pubescence, pale yellow, somewhat straw-colour with a narrow basal and lateral fulvous margin which disappears, however, when the colour turns to reddish fulvous, which is occasionally the case, and having 
on each side a narrow humeral longitudinal black band, two series of three equi-distant spots or patches disposed diagonally from the suture to the outer margin, and a supra-apical diagonal arcuate patch consisting evidently of two gglomerated apatches the outer of which reaches the outer margin which from there to the suture is moderately narrowly black. Easily recognised by the colour of the antennæ.

Length $7 \frac{1}{2}-13 \mathrm{~mm}$. ; width $3-4 \frac{1}{2} \mathrm{~mm}$.

Hab. Transvaal (Potchefstroom, Waterberg, Zoutpansberg); Southern Rhodesia (Bulawayo, Plumtree, Gwanda).

\section{Decatoma undata, Thunb., Plate XXIV., fig. 106.}

Dissert. Nov. Ins. Sp., vi., p. 114, f. 17 ; Billb., Mon., p. 40, pl. 4, figs. 16, 17 ; Mars., Mon., p. 573, pl. 6, fig. 2.

undatobifasciata, De Geer., Ins., vii., p. 649, pl. 48, figs. 15, 16.

Black, clothed with a black pubescence, but flavescent on the narrow yellow bands of the elytra and in the posterior part of the same; antennæ black, the apical joint swollen outwardly at about the median part, and on that account sharply acuminate at the apex; head and prothorax deeply and closely punctulate, the punctures plainly rugose, frontal part with an indistinct smooth patch; elytra deeply punctate shagreened, each with a yellow basal dorsal lunule the arcuate patch of which reaches the suture, and a narrow humeral line continued along the outer margin and connected there with the very narrow ante-median yellow band both edges of which are broadly but not very deeply bi-sinuate, the post-median band is not broader than the anterior, and has very nearly the same shape, the part of the anterior band abutting on the outer margin is occasionally prolonged behind there for a short distance. The last joint of the antennæ is strongly swollen outwardly, more so than in any other species of South African Decatoma.

Length $9 \frac{1}{2} \mathrm{~mm}$.; width $3 \frac{1}{2} \mathrm{~mm}$.

Hab. Cape Colony (Cape Town, Stellenbosch, Paarl, Worcester, Ceres, Malmesbury).

\section{Decatoma stellenboschiana, n. sp., Plate XXIV., fig. 107.}

This may prove to be only a varietal form of $D$. undata, but the punctuation of the elytra is deeper, broader, more irregular, and the latter are therefore more shagreened; on each elytron the basal dorsal yellow lunule has become coalescent along the suture and also on the dorsal part, the anterior band including thus between the median dorsal part and the 
suture a moderately large patch of the black background, the humeral patch is continued along the margin as a narrow band coalescing there with the anterior band the hind border of which is produced behind along the suture as a sub-quadrate projection, and is bi-sinuate thence to the outer margin, the post-median band is narrow, of nearly equal width throughout, and each border is plainly bi-sinuate; the apical flavescent pubescent patch is distinct. The last joint of the black antennæ is similar in shape to that of $D$. undata.

Length $8 \mathrm{~mm}$; width $3 \frac{1}{2} \mathrm{~mm}$.

Hab. Cape Colony (Stellenbosch).

\section{Decatoma contorta, Péring., Plate XXIV., fig. 108.}

Trans. S. Afric. Phil. Soc., iv., 1888, p. 132, pl. 3, fig. 6.

Allied to $D$. undata, which it seems to replace in the Transvaal. It is somewhat larger; the pubescence on the head and prothorax is silky flavescent instead of being greyish black, and the sculpture is more closely set, but that of the elytra is almost similar; the last joint of the antennæ is strongly swollen outwardly in the manner of $D$. undata and stellenboschiana; on the elytra the outer part of the basal dorsal lunule is prolonged as far as the fore edge of the median part of the anterior transverse fascia of which, like in the post-median one, both edges are very sharply tri-sinuate.

Length $11 \mathrm{~mm}$. ; width $4 \frac{1}{2} \mathrm{~mm}$.

Hab. Transvaal (Potchefstroom, Bocksburg, Pietersburg); Cape Colony, Bechuanaland.

I have seen examples in which the bands of the elytra are as narrow as in examples of D. undata, from which they can be distinguished only by the less swollen apical joint of the antennæ.

\section{Decatoma africana, Oliv., Plate XXIV., figs. 109, 110.}

Entom., iii., 47, p. 12, pl. 2, fig. 21 ; Mars., Mon., p. 571, pl. 6, fig. 4.

? decipiens, Mars., p. 574, pl. 6, fig. 3 .

Black, covered with a pubescence greyish underneath, black and greyish flavescent on the prothorax, and black on the elytra even on the yellow patches or bands; antennæ black; head and prothorax very closely pitted, the punctures separated by narrow, raised, irregular walls, frontal part with a not very distinct median line; elytra very closely pitted, the punctures forming a shagreened surface on the black background, but with the intervals smooth on the pale yellow part which, in 
the type form (fig. 109), invades the greatest part of the surface, the suture is narrowly black from the scutellum to about one-fourth of the length where it expands into a quadrate black patch extending on each side, and at about the middle is a small, sub-triangular dot; on the humeral part is a long black band slightly broader at apex than at base and reaching from there to one-fourth of the length; at about the median part is a subquadrate black dorsal patch, and the apical part is also black, the lower edge of the yellow part being there denticulate and sinuate; the supraapical flavescent patch is somewhat reduced.

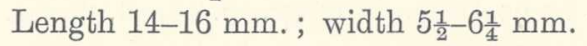

Hab. Cape Colony (Ceres, Stellenbosch, Worcester).

The normal form (fig. 110), which is the rarer of the two, has on each elytron a basal dorsal comma-shape patch and a lateral band connected along the margin with the anterior transverse band which is triangularly dilated along the margin, strangulated in the centre, irregularly dilated along the suture and sending close to it a hind spur which does not reach the posterior band, the latter is slightly broader and shaped in the same manner, viz., the anterior border is incised in the centre, the posterior is straighter along the suture and narrowly bi-incised thence to the outer margin.

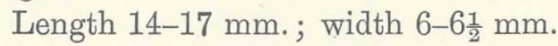

Hab. Cape Colony (Cape Town, Stellenbosch, Malmesbury).

\section{Var. INSOLITA, \\ Plate XXIV., fig. 111.}

Size, shape, and colouration of $D$. africana; the pubescence on the head and prothorax is, however, more flavescent, and the punctuation of the prothorax is not so deep and is slightly more irregular; there is on each side a somewhat large basal dorsal patch the inner edge of which reaches close to the suture, the patch itself being slightly slanting towards it, the lateral patch is narrow but as long as the dorsal, the anterior yellow band which, like the post-median one, reaches from the suture to the outer margin without any connection along the margin is somewhat broadly scooped in the centre of the border, the hind one is 3-incised and emits near the centre of the disk a spur which occasionally reaches as a narrow streak the post-median band which is not broader than the anterior, and is as deeply but more narrowly scooped in the centre of the anterior border, while the strongly bi-sinuate hind border emits a central, elongate rounded lobe.

Length 12-15 mm.; width 5-6 mm.

Hab. Cape Colony (Kimberley). 
The pattern of the elytra is not unlike that of a varietal form of D. africana, but the bands and lateral patch are not connected along the outer margin, and the median prolongation behind of the hind border of the posterior band is very different. I have seen two examples only, and on that account I hesitate to propose this variety as a valid species.

\section{Decatoma quadriguttata, Wulf.,} Plate XXIV., fig. 112.

Insect. Capens., p. 18, pl. 1, fig. $7 a b$; Billb., Monogr., p. 44, pl. v., fig. 4. nigricornis, Mars., Monogr., p. 577, pl. 6, fig. 5.

Black, clothed underneath with a black pubescence; on the prothorax the pubescence consists of black erect hairs mixed with a few flavescent greyish ones; antennæ black, the last joint elongated, acute at tip; head and prothorax closely scrobiculate punctate; elytra closely shagreened and each with three moderately distinct costules; they have on each side a round basal dorsal pale yellow patch, a briefly elongated lateral one, an anterior somewhat narrow band reaching from the suture to the outer margin, bi-sinuate on each side or slightly strangulate at about the middle, and a post-median one broader than the anterior, scooped in the centre of the anterior border, bi-incised or less deeply scooped in the posterior, the part of the band abutting on the outer margin narrower than that abutting on the suture.

\section{Var. Minuta, Plate XXIV., fig. 113.}

Casteln., Hist. Nat. Ins., ii., 1840, p. 268; Billb., Monogr., p. 44, pl. v., fig. 3 ; Mars., Monogr., pl. 6, fig. 6.

4-guttata, Mars. nec Wulf., pl. 6, fig. 7.

Similar to the type; the two basal patches are alike, but the anterior and post-median patches are very distinctly interrupted in the centre of the dorsal part. These yellow markings form thus a juxta-sutural series of three sub-transverse patches and a marginal series of slightly narrower, and with the exception of the humeral, more transverse patches.

Length 10-15 mm. ; width 4-6 mm.

Hab. Cape Colony (Cape Town, Stellenbosch, Paarl, Worcester).

\section{Decatoma namaqua, n. sp., Plate XXIV., fig. 114.}

Like $D$. quadriguttata, but the punctures on the head, and the prothorax especially, are somewhat wider and coarser, and on the latter is a 
very plain longitudinal smooth line; on the elytra the three costules of each are very plain, the three juxta-sutural patches are replaced by a mere yellow dot, but the outer marginal patches are only slightly smaller than in D. quadriguttata.

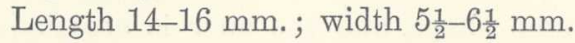

Hab. Cape Colony; Namaqualand.

This is very closely allied to the preceding one, and may prove to be only a varietal form, but it occurs only in Namaqualand, where it seems to be very constant.

Decatoma adamantina, Péring., Plate XXIV., fig. 115.

Trans. S. Afric. Phil. Soc., viii., 1888, p. 131, pl. 3, fig. 7.

Black, clothed underneath with a dense black pubescence, on the head and prothorax this pubescence is not very dense, and it is extremely short and almost invisible on the elytra except in the posterior part; antennæ yellow with the two basal joints black, patches and bands on the elytra yellow except the supra-apical patch which is red; head and prothorax punctate, punctures round, smooth, and set moderately close to each other but not contiguous at the apex of the head and on the posterior part of the prothorax; elytra with the three costules distinct, punctate shagreened on the black background, less shagreened on the yellow patches and bands which are disposed as follows: a basal dorsal large rounded patch eoalescing or nearly coalescing with an equally large lateral patch, anterior band moderately broad, bi-sinuate in the fore border, tri-sinuate in the posterior and also dentate there, posterior band as broad as the anterior and equally bi-sinuate, but without the tooth; at an equal distance from this band and from the apical border, and set in the inner part of the disk is an ovate red patch.

Length 15-19 mm.; width 5-7 mm.

Hab. Cape Colony (Victoria West, Beaufort West, Kimberley).

\section{Decatoma histrio, Mars., Plate XXIV., figs. 116-117.$$
\text { Monogr., p. 581, pl. 6, fig. } 8 .
$$

Black, clothed on the under and upper sides with a very dense flavescent greyish pubescence, appressed but also dense on the elytra; antennæ black but with the joints 3 and 4 slightly rufescent; head and prothorax very finely and closely punctate; elytra with only the median dorsal costule usually distinct, the black background is closely and finely shagreened, the pale yellow bands and patches being deeply but not 
closely punctulate, on each side is a basal dorsal transverse or sub-arcuate patch set at a short distance from the base, and a lateral small one; the anterior band is narrow, deeply scooped at about the median part of the anterior border and emits on the posterior border a straight median spur, the post-median one is of the same shape, and the spur is occasionally connected with a slanting yellow or occasionally orange-red posterior patch with the fore border bi-incised and the hind one with only one incision.

Length $12 \frac{1}{2}-16 \mathrm{~mm}$; width $4 \frac{1}{2}-5 \mathrm{~mm}$.

Hab. Cape Colony (Victoria West, Beaufort West, Uniondale, Grahamstown, Uitenhage, Fort Beaufort).

\section{Gen, CORYNA, Billb.,} Plate XXIV., fig. 118.

Monogr. Mylabr., 1813, p. 73.

Antennæ 9-jointed, apical joint very swollen and convex outwardly.

\section{Key to the Species.}

$\mathrm{A}^{2}$. The five basal antennal joints black, the others yellow, legs black.

Elytra with a dorsal and a lateral basal patch, two transverse bands and one apical patch.

Body densely pubescent; basal dorsal lunule continued as an elongated band connected by a narrow spur or line with the anterior transverse band which is interrupted laterally, the humeral band is prolonged as a narrow marginal band from the base to the apical patch which is strongly constricted in the centre (pl. xxiv., fig. 119) pilosa.

Basal dorsal lunule forming a quadrate patch connected with the entire median band, the lateral humeral band continued along the whole margin (pl, xxiv., fig. 121)

The two median transverse bands coalesce, forming a broad band

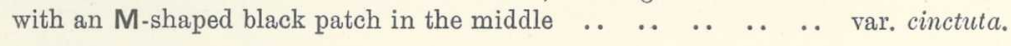

Basal dorsal lunule coalescing with the anterior band which coalesces also with the post-median one, forming thus a very broad yellowish band with two spots of the background left, lateral band connected along the margin with the transverse band (pl. xxiv., fig. 122

Body very little pubescent, transverse bands not connected along the outer margin (pl. xxiv., fig. 120)

$\mathrm{A}^{3}$. The four basal antennal joints black, the others yellow.

Elytra each with three dorsal round yellow patches and three lateral marginal ones (pl. xxiv., fig. 123).. 
$A^{2}$. All the antennal joints rufescent; legs also rufescent.

Elytra with a lateral flavescent uninterrupted border, a basal transverse marginal band connected near the suture with the first of three seriate round dorsal patches, and three lateral patches connected with the outer border (pl. xxiv., fig. 124)

$A^{x}$. The two basal joints of antennæ black, the others yellow.

Outer margin with a broad band beginning at the shoulder, ampliate in the middle, not reaching the rounded apical part, basal lunule nearly longitudinal, median band bi-sinuate, connected with the lobate part of the margin, second band interrupted at the suture and

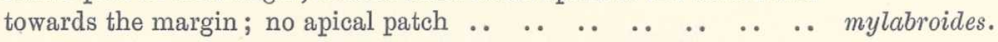

\section{Coryna pilosa, Făhr., Plate XXIV., fig. 119.}

Öfv. Vet. Ak. Förh., 1870, p. 347.

mixta, Mars., Monogr., p. 605, pl. 6, fig. 7.

posthuma, Mars., loc. cit., p. 603, pl. 6, fig. 6.

Black, clothed on the lower and upper side with a very dense, silky flavescent pubescence much shorter and more appressed on the elytra than on the head and prothorax ; antennæ with the five basal joints black and the other four rufo-flavescent; head and prothorax closely punctate, the punctures not rugose, frontal part with a very plain raised line; elytra elongated, punctate shagreened, patches and bands yellow, on each side are a basal dorsal lunule the curving inward part of which reaches the suture, and a lateral marginal short band, reaching the anterior transverse band which is moderately deeply bi-incised on each border between the suture and the median dorsal part, narrowly interrupted there, and continued to the margin; the posterior band is equally narrow with each border bi-sinuate or bi-incised; in the apical part are two coalescent macules forming a slanting patch strangulated in the centre. In many examples from Northern Damaraland the outer apical angle of the basal dorsal lunule is narrowly connected with the median part of the anterior band.

Length 12-14 mm. ; width 4-5 mm.

Hab. Northern Damaraland; Ovampoland.

Var. Distincta, Plate XXIV., fig. 121.

Voigts, Wien. Ent. Zeit., xxi., 1902, p. 177.

apicalis, Pér., Trans. S. Afr. Phil. Soc., viii., 1886, p. 133 (nam. preocc.).

Size and shape of the type form C. pilosa, and equally densely flavous pubescent, but differs by the disposition of the yellow markings on the 
elytra; the two basal lunules have become a quadrate patch, connected on the outer side by a narrow line with the median transverse band which is broader than in the type form and more sharply zigzagged; the humeral narrow band is continued along the margin and joins the apical patch at the apex.

Length $12 \mathrm{~mm}$.; width $4 \frac{1}{2} \mathrm{~mm}$.

Hab. Transvaal (Potchefstroom, Lydenburg).

Var. сіnстuta, Mars., Monogr., p. 600, pl. 6, fig. 4.

In this variety the two median transverse yellow bands have coaleseed, forming thus a single broad band having however in the centre an M-shape patch of the colour of the background, and a smail triangular black notch along the suture.

Length $13 \mathrm{~mm}$. ; width $3 \frac{3}{4} \mathrm{~mm}$.

Hab. Kaffraria, teste Marseul.

I have not met with this variety, of which the var. matabelena is an extreme form.

\section{Var. matabelena, \\ Plate XXIV., fig. 122.}

Smaller than the type form; the lower part of the dorsal lunule is produced into a large quadrate patch reaching the suture, the outer angle is connected with the anterior band which has coalesced with the postmedian forming thus a very broad yellow area equal in width to half the length of the elytra, and enclosing three small dot-like spots in the centre of the disk, the lateral basal band is connected with the broad yellow band the hind border of which is tri-dentate; the apical patch is of the normal shape.

Length $9 \mathrm{~mm}$.; width $4 \mathrm{~mm}$.

Hab. Southern Rhodesia (Bulawayo).

$$
\begin{aligned}
& \text { Var. apicipustulata, Mars., } \\
& \text { Plate XXIV., fig. } 120 . \\
& \text { Monogr., p. 602, pl. 6, fig. } 5 .
\end{aligned}
$$

Black, clothed underneath with a short black pubescence which on the head and prothorax is mixed with sub-flavescent hairs ; on the elytra the pubescence is short, flavescent on the yellow patches and bands, black on the black background, whereas in C. pilosa it is longer, denser, and entirely flavescent; the five basal antennal joints are black, the other four flavous; head and prothorax very closely punctate; elytra very 
closely punctate, not shagreened, but the punctures are slightly rugose; bands and patches bright yellow, on each side are a basal dorsal lunule strongly arcuate at apex towards the suture which it reaches, and a lateral short marginal band, the anterior transverse band is straight in the fore border, the hind one is dilated close to the suture and moderately deeply bi-sinuate from the middle to the outer margin, the post-median band is narrower than the anterior, attenuated from the middle to the outer margin and with each border bi-incised there, the apical patch is plainly divided into two.

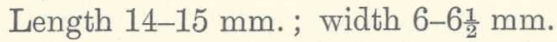

Hab. Natal? (Durban).

Coryna Lugens, Făhr., Plate XXIV., fig. 123.

Ofv. Vet. Ak. Förh., 1870, p. 347.

wahlbergi, Mars., Mon., p. 612, pl. 6, fig. 13.

Black, clothed underneath and on the head and prothorax with a dense appressed flavescent pubescence, on the elytra the pubescence is very short, but dense; the four basal antennal joints are black, the other five rufo-flavescent; head and prothorax deeply pitted, the punctures rugose on the frontal part which bears no traces of a median line, and in the anterior part of the prothorax, more even in the posterior; elytra closely punctate shagreened, especially on the lateral part, each one has a juxtasutural longitudinal row of three rounded pale yellow patches, the first basal, the second median, the third post-median, and along the outer margin are also three patches, the first is humeral, and the other two which are quadrate or sub-triangular are situated nearly opposite the juxtasutural ones.

Length 9-11 mm.; width $4 \frac{1}{2}-4 \frac{3}{4} \mathrm{~mm}$.

Hab. Natal (Durban, Isipingo).

Coryna argentata, Fábr., Plate XXIV., fig. 124.

Ent. Syst., ii., 1791, p. 90.

Black, with the palps, the whole antennæ, the legs and tarsi rufescent; the whole body is thickly clothed with an appressed golden-yellow pubescence, and the head, prothorax, and elytra bear in addition dense erect hairs flarescent on the two first-named parts and black on the elytra; head very closely punctate; antennæ short, intermediate joints small, closely set, apical one thickly clubbed, and intermediate in thickness with that of the other species of the genus and of Actenodia; 
prothorax as closely punctate as the head; elytra somewhat deeply pitted, the punctures separated from each other by an interval almost equal to their own diameter, and without any traces of costules; each one has a very plain uninterrupted dark orange-yellow border reaching from the humeral part to the suture, and broader on the rounded apical part, a transverse marginal narrow basal band, curving outwards at a short distance from the suture and uniting with the first of three somewhat large, transverse rounded, seriate, dorsal, dark orange-yellow patches the last of which is situated at about three-fourths of the length; on the lateral part are three sub-triangular patches not in a line with the three dorsal ones, and with their base connected with the lateral border; occasionally the apex of the second lateral patch is connected upwards with the second dorsal patch.

This species is easily recognised by its thick golden-yellow vestiture.

Length 8-10 mm.; width $3 \frac{1}{4}-4 \mathrm{~mm}$.

Hab. Mozambique (Beira). It is evidently a straggler. The species is recorded from Egypt, Senegal, and India (Bengal).

\section{Species not identified.}

Coryna (Mylabris) 12-guttata (Klug),

Germ. Spec., 1824, 171, 283.

"Bristling with hairs, black; elytra adorned with six round flavous spots. Small, entirely black, punctate, elytra adorned with six round flavous spots : first oblong, situated behind the shoulder, second near the scutellum, third and fourth before the middle, fifth and sixth beyond it. Cape of Good Hope."

\section{Coryna mylabroides, Cast.,}

Hist. Nat. Ins., ii., 1840, p. 208; Mars., Monogr., p. 607, pl. 6, fig. 8.

lanuginosa, Gerst., Monatsb. Berl. Ac., 1854, p. 695; Peter's Reis., 1862, p. 303, pl. 18, fig. 4 .

Elongated, sub-parallel, little convex, black, moderately shiny, clothed with a greyish silky pubescence; head closely punctate like the prothorax, inflated behind the reniform eyes, frontal part convex, labrum bi-lobate, \&c., antennæ red with the two basal joints black; pronotum hardly oblong, dilated, rounded externally, coarctate and narrowed in front, reflexed at base, moderately convex and bi-impressed in the dorsal part; scutellum lobate; elytra with the shoulders raised, rounded at apex, densely reticulate punctate with the nervures obsolete, the three marginal pale yellow macules are connected, the median one being ampliate lobate, and connected with the median, sub-oblique patch, the lower margin is 
strongly bi-sinuate, the basal lunule is narrow, nearly longitudinal, and opposite the lobate part of the third marginal macule is a transversely oblong median one.

I have not met with this species, the description of which is partly culled from Marseul, and partly made from the figure he gives in his Monographie des Mylabres. It differs from C. pilosa and varieties of the same in the disposition of the pale yellow bands the third dorsal one of which is broadly interrupted, and there is no apical patch; in addition to this difference only the two basal joints of antennæ are black, whereas in C. pilosa the five basal joints are of that colour.

Length $11 \mathrm{~mm}$. ; width $3 \frac{1}{2} \mathrm{~mm}$.

The species is recorded from Egypt, Angola, and Mozambique.

Gen. ACtenodia, Cast., Plate XXIV., fig. 125.

Hist. Nat. Ins., ii., 1840, p. 268.

Antennæ 8-jointed, apical joint very swollen, especially on the outer side where it is very convex.

\section{Key to the Species.}

$\mathrm{A}^{3}$. Patches and bands of elytra pale yellow; two basal patches and two transverse bands.

A basal dorsal round, and a lateral arcuate pale yellow patch, anterior band interrupted in the centre, posterior formed by two transverse patches broadly coalescing in the centre (pl. xxiv.,

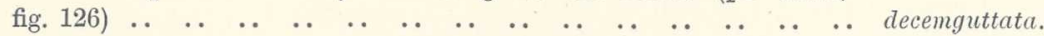

Patches and bands of elytra orange-yellow or orange-red.

The same but the anterior band is not interrupted in the centre although strongly constricted there, posterior band broad, not reaching the apex, and with both edges sinuate (pl. xxiv., fig. 127) ..

curtula.

$\mathrm{B}^{2}$. Antennæ black.

$\mathrm{A}^{2}$. Patches and bands of elytra orange-yellow; basal patches and anterior band united; posterior invading the apex.

Elytra orange-yellow, with a broad, transverse bi-sinuate band not reaching quite the outer margin, a post-median bi-dentate one extending from side to side, a supra-apical dot, and a marginal apical band black (pl. xxiv., fig. 128)

$\mathrm{B}^{\mathrm{r}}$. Antennæ yellow with the two basal joints black.

The same, but with the anterior band reduced to a triangular patch along the suture, a dorsal minute black spot (pl. xxiv., fig. 129) 
$A^{x}$. Elytra with two longitudinal series of yellow patches, apical margin yellow.

Elytra each with four round pale yellow patches disposed longitudinally in the dorsal part, and three lateral supra-marginal ones connected with the yellow margin which runs from the base to the apex, and is broader there than laterally (pl. xxiv., fig. 130) $\quad . \quad$.. jucunda.

Elytra with three orange-red dorsal patches, a humeral and two lateral ones, the outer margin is broadly orange-red from past the middle where it is connected with the second lateral patch, to the rounded apex (pl. xxiv., fig. 131)

\section{Actenodia décemguttata, Thunb., Plate XXIV., fig. 126.}

Nov. Spec. Ins., vi., 1791, p. 234, pl. xi., fig. 13; Billb., Mon., pp. 45, 31, pl. 5, fig. 5 .

guttata, Cast., Hist. Nat. Ins., ii., 1840, p. 268, fig. 192.

Black, clothed with a dense, black pubescence also very long on the elytra, but appressed there; head and prothorax covered with deep, closely set punctures, confluent, and with raised walls on the prothorax; antennæ entirely back; elytra coriaceous shagreened with the costules indistinct, the bands and patches are pale yellow and disposed as follows : a basal dorsal ovate patch, and a lateral marginal elongated one, a sub-median juxta-sutural ovate patch, and opposite a triangular marginal one reaching very close to it, a post-median band consisting plainly of two more or less ovate patches broadly connected at each end.

Length $9 \frac{1}{2} \mathrm{~mm}$.; width $4 \frac{1}{2} \mathrm{~mm}$.

Hab. Cape Colony (Cape Town, George).

Actenodia curtula, Făhr., Plate XXIV., fig. 127.

Öfv. Vet. Ak. Förh., 1870, p. 349.

rufonigra, Mars., Mon., p. 628, pl. 6, fig. 5.

Shape and size of $A$. decemguttata, from which it differs in the less deeply punctate prothorax, and with the intervals of the punctures plane instead of being produced into a raised wall; the black pubescence is also much shorter on the upper side; all the antennæ joints are totally black; the patches and bands of the elytra are orange-yellow; in the type form the basal dorsal and lateral marginal patches are small and clearly defined, the ante-median band is complete with each border deeply bi-sinuate, the post-median band is broader from the suture to about the median part 
and narrowed thence to the outer margin with the two borders bi-incised.

Length $10 \mathrm{~mm}$; width $4 \frac{1}{4}-4 \frac{1}{2} \mathrm{~mm}$.

Hab. Cape Colony (Dunbrody), Natal (Eshowe, Durban).

\section{Actenodia chrysomelina, Erichs., Plate XXIV., fig. 104.}

Wiegm. Arch., 1843, p. 258 ; Mars., Monogr., p. 629, pl. 6, fig. 6.

wahlbergi, Făhr., Öfv. Vet. Ak. Förh., 1870, p. 349.

Black, clothed with a dense black pubescence on the under side and on the head and prothorax; this pubescence is also very long and erect, but less dense on the elytra; it is also often totally wanting on the upper side; all the antennal joints black; the punctures on the head and prothorax are somewhat scattered and shallow with the intervals smooth; the elytra are closely coriaceous on the orange-yellow parts, finely punctate on the black, and the costules are moderately distinct; the orange-yellow basal patches and the ante-median bands have invaded nearly the whole of the anterior part of the disk, including however a triangular sutural patch, a smaller more central one, and a minute dot disposed transversely, all three being the remains of the band of the black background that separated the two anterior bands from the basal patches; the post-median band has also invaded the whole posterior part, except for a narrow apical black border, and a minute black dot in the centre of that broad patch.

Length 6-9 $\frac{1}{2} \mathrm{~mm}$. ; width $2-4 \frac{1}{2} \mathrm{~mm}$.

Hab. Transvaal. The whole of the Transvaal, Mozambique, Ovampoland, Damaraland. Has not to my knowledge been recorded as yet from Natal, nor from the Cape Colony.

\section{Actenodia discrepans, n. sp., Plate XXIV., fig. 129.}

Resembles almost completely the type form of A. chrysomelina; but the colour of the antennæ differs, the antennal joints with the exception of the two basal ones which are black, being flavo-rufescent, but joints 3 and 4 are somewhat dull yellow; in the elytra the orange-yellow colour has invaded nearly the whole of the anterior part except for a small triangular, sutural black patch and a smaller one often reduced to a mere dot in the centre of the disk; the whole posterior part is orange-yellow except for a minute median dot and a very narrow fringe of the apical margin which are black.

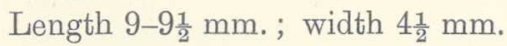

Hab. Transvaal (Middle Limpopo; Waterberg). 


\title{
Actenodia jucunda, Erichs., Plate XXIV., fig. 130. \\ Wiegm. Arch., i., 1843, p. 257.
}

Black, clothed with a very dense, partly appressed flavescent, silky pubescence; legs rufo-flavescent with the knees infuscated and the tarsi black; labrum rufescent; antennæ black; prothorax very elongated, onethird longer than broad, and much attenuated in front, both the head and prothorax are very closely punctulate, the punctures small, but deep and rugose; elytra punctate shagreened and with some erect hairs in addition to the sub-appressed flavescent pubescence, the patches are pale yellow and disposed as follows: four sub-median dorsal ones, somewhat ovate, the fourth situated at about four-fifths of the length, three lateral marginal, sub-triangular ones set opposite the corresponding dorsal ones, but all connected along the margin by a narrow pale flavescent band running from the humeral basal part to the rounded part of the suture and wider in the apical part than along the lateral margin. I have seen examples in which the legs are totally black.

Length 7-8 $\mathrm{mm}$.; width $2 \frac{1}{2}-2 \frac{3}{4} \mathrm{~mm}$.

Hab. Southern Rhodesia (Sebakwe), Ovampoland.

\author{
Actenodia amoena, Mars., \\ Plate XXIV., fig. 131. \\ Monogr., p. 621, pl. vi., fig. 1.
}

Black, clothed with a short, silky flavescent pubescence; tibiæ rufescent; antennæ black; head and prothorax very closely, and somewhat roughly punctate, the punctures small and confluent; prothorax elongated, one-third longer than broad, much attenuated in front; elytra plainly shagreened, with the patches orange-yellow and disposed as follows: three juxta-sutural somewhat ovate rounded ones, the first basal and more elongated than the other two, the second median, the third postmedian, along the outer margin is a humeral elongated patch disconnected from the second and the third which are prolonged along the margin and situated slightly above the opposite dorsal ones; the posterior however is continued along the margin right to the suture, thus forming in the apical part a plain, moderately narrow band. In this species the apical antennal joint is much more elongated and much less club-shaped than in the other South African species known to me.

Length $8 \mathrm{~mm}$.; width $3 \mathrm{~mm}$.

Hab. Cape Colony (Namaqualand). 
Actenodia villosa, Mars., Monogr., p. 625, pl. vi. (iv.), fig. 3.

Marseul, loc. cit., describes an Actenodia which differs from A. amoena merely by having all the antennal joints, the basal parts, and the legs yellow. The habitat of this species, "Cape of Good Hope," is however considered by him as doubtful. I have not met with it.

Gen. PARACtenodia, Péring., Ann. South Afric. Mus., iii., 1904, p. 285.

Characters of Actenodia, Casteln., from which it differs in the number of antennal joints which is seven instead of eight.

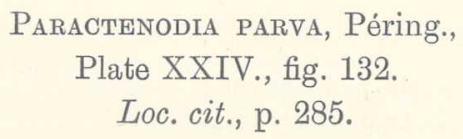

Black, with the five ultimate joints of the elytra and the tibiæ red; covered with a very short, appressed silky pubescence; head deeply and closely punctate and with a faint, smooth, longitudinal area in the middle of the frontal part; prothorax only moderately narrowed laterally in the anterior part, as broad as long, scrobiculate punctate with the punctures very closely set, and plainly impressed longitudinally in the posterior part ; elytra coarsely shagreened, without any costules, patches and bands yellowish red, the anterior elongated band is formed by a longitudinal basal patch reaching the median bi-sinuate transverse band which is disconnected from the suture, but continued upwards into a somewhat broad band along the outer margin as far as the humeral part where it coalesces anew with the basal patch which has invaded all the base, this basal band reaches the suture in the anterior part only, and the result of the amalgamation of this basal patch and band gives to the elytra the appearance of being yellowish red from the base to the median part, except for a narrow strip along part of the suture, and enclosing a humeral, narrow black band; the second band is equidistant from the first and from the apex, strongly sinuate and narrowly disconnected from the suture, but not from the outer margin. The last joint of the antennæ which is nearly equal in length to the four preceding ones taken together, is very thick, but arcuate as in Coryna.

Length $4 \frac{1}{2}-5 \mathrm{~mm}$; width $2 \frac{1}{2} \mathrm{~mm}$.

Hab. Cape Colony (no exact locality). 


\section{TRIBE CANTHARINI.}

Maxillary lobes normal in shape; antennæ always 11-jointed, more or less compressed, of variable shape, but never with the last joint knobby; prothorax mostly campanulate, but occasionally sub-transverse; elytra broad, sub-depressed (Eletica), or more or less cylindrical; legs long, somewhat compressed laterally, tarsi always long, variable in shape; claws usually cleft from apex to base, but there are exceptions in the South African species in which moreover the upper part of the said claw is always simple.

\section{Key to the Genera.}

$\mathrm{A}^{2}$. Head not acuminate in front.

$B^{2}$. Elytra broad, depressed.

a3. Antennæ short, the joints serrate or strongly serrate inwardly; tarsal joints short, very broadly triangularly incised $\quad$.. $\quad$.. $\quad$ Eletica.

$B^{\mathrm{r}}$. Elytra cylindrical or sub-cylindrical.

$a^{2}$. Antennæ longer, the joints flabellate inwardly. $\begin{array}{lllllll}\text { Tarsal joints not triangularly incised .. } & . . & \text {.. } & \text {.. } & \text {.. } & \text {. } & \text { Prionotolytta. }\end{array}$

$a^{\mathrm{x}}$. Antennæ neither serrate nor flabellate inwardly.

Antennæ very long and greatly compressed; body dark blue or blue-black, pectus with a conspicuous red patch .. $\quad . \quad$ Cyaneolytta.

Antennæ very long, filiform, mandibles strongly developed, vaulted and curving backwards ..

Antennælong or short, mandibles normal, pubescent or glab-

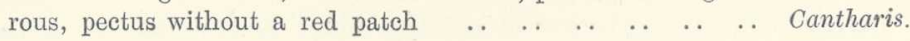

\section{Gen. ELETICA, Lacord., Plate XXII., fig. $5 a$.}

Gen. d. Coléopt., v., 1859, p. 672.

Mentum transverse, ampliate laterally, with the upper angles rounded, and the basal ones sharp, concave, ligula as long as the mentum, membranaceous, so broadly and deeply scooped as to be bi-lobate, labial palps short; apical joint eylindrical, implanted on the penultimate which is elongate conical ; maxillæ robust, inner lobe broad, densely ciliate pubescent, upper lobe sub-spatuliform, also densely ciliate pubescent; maxillary palps short, first and second joints of nearly equal length, third shorter, conical, last one sub-pyriform; antennæ short, not reaching the shoulders strongly compressed, intermediate joints thickly serrate outwardly, more closely set in the male than in the female, apical joint slightly coarctate, and 
looking as if divided into two ; mandibles robust, sharply falcate; labrum moderately short, scooped in the centre; head sub-quadrate, frontal part strongly sloping, gibbose; prothorax longer than broad, with the anterior part strongly attenuate and sloping, and the posterior one convex; base plainly marginate; scutellum broadly triangular, but sub-truncate at apex; elytra elongated, sub-parallel, plane past the basal part; bi-costulate on each side, but with the two costæ and two other intervening ones highly carinate in the basal part for about one-fourth of the length in the $\delta$; in the o these intervening costæ are not much more raised than the costules; five visible abdominal segments in both sexes, the apical one much narrower in the $\delta$ than in the $q$; legs moderately long; tarsi with the intermediate joints very broadly triangular and deeply incised in the $\delta$, more elongated and narrower in the of claws double, the upper tooth strong, compressed and dilated at the base, bent almost at right angles there, the lower claw in the shape of a stiff bristle; outer spur of hind tibiæ subspatulate, short, inner one not longer than the outer, moderately acute.

Few Coleoptera vary more in colouration than the species included in this genus. This variation is not restricted to sex only. It is quite possible that one of the South African species may prove identical with E. rufa, of the Guinea coast. Several species have been described from German and British East Africa, and one from Somaliland.

\section{Key to the Species.}

$\mathrm{A}^{2}$. Prothorax very closely and roughly punctate all over in both sexes.

Black, with the vertex, a small patch on each side of the prothorax, the anterior half of the elytra and the legs yellow $\sigma^{t}$; elytra black in the + , more or less broadly marginated with cinnabar.. .. .. ..

Totally black in the male with the exception of the vertex, which is

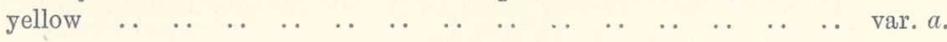

$\mathrm{A}^{\mathrm{x}}$. Prothorax finely and closely punctulate on the attenuate part and almost smooth in the posterior ( $\delta$ ), less sparsely punctulate in the $q$.

Black, with the palps, labrum and vertex and a lateral patch on each side of the prothorax yellow ( $\delta$ ), elytra cinnabar red, with a more or less broad, median black band on each side $(q)$.

Body totally black, with the exception of the labrum which is $\begin{array}{llllllllllllll}\text { flavescent } & \ldots & \ldots & \ldots & \ldots & \ldots & \ldots & \ldots & \ldots & \ldots & \ldots & \ldots & \ldots & \ldots\end{array}$

Black, with a lateral yellow patch on the prothorax; labrum, legs, and whole abdomen zellow.. patch on the prothorax; labrom, legs,

Pectus, anterior frontal part and antennæ black; abdomen, legs, vertex, prothorax with the exception of a median black band, yellow, the elytra from the base to past the median part cinnabar red or yellow; posterior part of elytra black 8 ; $\&$, elytra cinnabar red with a broad, longitudinal fuscous band; legs black $\ldots . \quad . \quad .$. cardinalis. 
Body black; elytra black, with two broad transverse yellow patches, a basal one enclosing two large black patches and a post-median

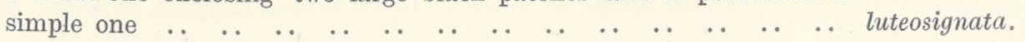

\section{Eletica posticalis, Péring.,}

Trans. S. Afric. Phil. Soc., iv., 1888, p. 135.

Male. Antennæ and anterior part of the frons, black; prothorax black, with a lateral rufescent yellow macule; elytra with the half anterior part yellow and the posterior black; labrum, legs and abdomen yellow, the former with the knees narrowly infuscate; under side and legs, and also the anterior part of the head, clothed with a sericeous grey pubescence, elytra glabrous; anterior part of the head deeply and closely punctate, the punctures rugose, vertex deeply canaliculated and sparingly punctate; prothorax with a deep, median grooved line, faintly impressed on each side of the disk, covered with closely set, sub-rugulose punctures from apex to base; scutellum aciculate; elytra elongated, broader at base than at apex, sinuate laterally at about the median part, very strongly coriaceous, and having on each side two costules which are carinate on the anterior part, where in addition are two short, intervening ones; upper part of anterior claws bent almost at right angles at the base.

Female. Body black, but the palps, epistome, and labrum and the sides of the head and the vertex are flavous; the lateral macule of the prothorax is less conspicuous than in the male; the elytra are fuscous black with a narrow border of cinnabar red; the head and prothorax are, if anything, slightly more closely punctate all over than in the male; the two costules on each elytron are less carinate in the anterior part and the intervening costules are not more distinctly raised than the other two; the sculpture is the same as in the male.

Var. $a$. Male. Totally black, with only the palps, the labrum and epistoma, and the apex of the head flavous.

Length 19-22 $\mathrm{mm}$.; width $6 \frac{1}{2}-7 \mathrm{~mm}$.

Hab. Transvaal (Potchefstroom), Southern Rhodesia (Enkeldoorn).

Eletica wahlbergi, Făhr. ( + ).

Öfv. Vet. Ak. Förhandl., 1870, p. 350.

E. verticalis, Făhr., loc. cit., p. 351 (ठ).

Male. Black, with the palps, the labrum and epistome, the vertex of the head, and a small lateral patch on the prothorax yellow; this lateral patch is occasionally wanting; the under side and legs are clothed with a dense appressed silky greyish pubescence, but the head is almost glabrous, the depressed anterior part of the frons is aciculate punctate, but the whole of the vertex is very sparingly punctulate and shiny; the pro- 
thorax is closely aciculate in the anterior attenuate part and very briefly pubescent there, but the remainder is shiny glabrous, and very sparingly punctulate; the elytra are coriaceous with the four basal costules strongly carinate.

Female. Black, with the elytra more or less broadly marginate with cinnabar red, the colour of the head and prothorax is as in the male, but the lateral yellow patch of the latter is broader, and the punctures are more closely set in the posterior part than in the male, and sometimes less shiny.

Length $18-21 \mathrm{~mm}$; width $6 \frac{1}{4}-7 \mathrm{~mm}$.

Hab. Southern Rhodesia (Matoppos, Salisbury, Enkeldoorn, Plumtree, Sebakwe).

Var. moerens, Péring.,

Trans. S. Afric. Phil. Soc., iv., 1888, p. 137.

Totally black in both sexes with the exception of the palps, and the apical part of the labrum. This is plainly the melanic variety of $E$. wahlbergi. The habitat is also the same.

Length $13 \frac{1}{2} \mathrm{~mm}$. ; width $20 \mathrm{~mm}$.

Hab. Transvaal (Rustenburg) ; Southern Rhodesia (Mazoe, Bulawayo, Salisbury).

\section{Var. Nigriceps, Péring.,}

Trans. S. Afric. Phil. Soc., iv., 1888, p. 136.

Male. Similar in shape and sculpture to E. wahlbergi, but differs in the colouring. Black, with the palps, labrum, a plain lateral prothoracic patch, the whole abdomen and the legs flavous.

Female unknown with certainty, but I suspect it to have black legs and cinnabar red elytra with a more or less wide black longitudinal band.

Length 17-19 mm.; width 6-6 $\frac{1}{2} \mathrm{~mm}$.

Hab. Southern Rhodesia (Victoria Falls; Bulawayo).

\section{Var. CaRdinalis, Péring., Plate XXII., figs. 5, $5 a$.}

Trans. S. Afric. Phil. Soc., iv., 1888, p. 135.

Male. Pectus, antennæ, anterior part of the front black, vertex red or yellow; prothorax red or yellow, with a quadrate central black patch in the anterior part, and continued thence as a narrow band to the base; elytra yellow or cinnabar red from the base to past the median part, and black thence to the apex; abdominal segments yellow, legs yellow or red.

This variety or species differs from E. wahlbergi, in having the anterior part of the prothorax less finely aciculate, but the difference is very slight. 
Female. Head and prothorax of the same colour as the male; the elytra are cinnabar red, with the usual broad longitudinal fuscous band, and the legs and abdomen are black.

Length 17-18 mm.; width 6-7 mm.

Hab. Southern Rhodesia (Bulawayo, Victoria Falls).

Eletica luteosignata, Făhr., Öfv. Vet. Ak. Förhandl., 1870, p. 349.

Black, palps also black except the very apical part of the ultimate one, femora black with a longitudinal rufescent line along the upper side, tibiæ and tarsi rufescent; elytra with a very broad transverse pale yellow band extending from the base to one-third of the length and enclosing a juxtasutural and a supra-lateral black patch, and a second, narrower band, situated past the middle, being almost equidistant from the centre and the apex $(\Im)$; or, prothorax with an anterior lateral triangular reddish yellow macule; elytra with a humeral yellow patch continued along the outer margin as a narrow border connecting or not with a transverse broad or narrow sinuate band reaching the suture at about one-third of the length, posterior transverse band broad or narrow sinuate or scooped; the pectus, abdomen, and legs are clothed with a dense, sericeous white pubescence; the head, especially in front, and the anterior part of the prothorax have a similar but less dense pubescence, the scutellum is very briefly pubescent, and the elytra glabrous. The head, including the vertical part, is closely punctate, and the vextex not shiny; the antennæ are shorter than in the preceding species, or varieties, and even in the $q$ barely reach beyond the median part of the prothorax, and the joints are very much less serrate; the prothorax is finely and very closely aciculate punctate in the anterior part, but with only a few very remote punctures in the posterior which is very shiny, in the manner of E. wahlbergi, and the sculpture of the strongly coriaceous elytra is the same.

In the female there is an apical rufo-flavescent band on the metasternum, and the black femora have a longitudinal streak of the same colour.

That $E$. luteosignata is not a colour variety of the preceding species is plainly shown by the shorter antennæ and the less serrate joints, and also by the sculpture of the vertical part of the head. I have seen only one example.

Length 15-28 mm.; width 5-10 $\mathrm{mm}$.

Hab. Southern Rhodesia (Sebakwe, Plumtree).

Eletica stuhlmanni, Kolbe, from the Albert Nyanza region, is a very close ally of, if not identical with, Făhrœus' species. 


\section{PRIONOTOLYTTA, n. gen.}

Facies and characters of Cantharis, but differs in the shape of the antennal joints which are compressed and with the joints 5-10 as strongly serrate flabellate inwardly as in the genus Eletica.

Prionotolytta binotata, Péring.,

Trans. S. Afric. Phil. Soc., iv., 1888, p. 139.

Black, clothed with a very dense, appressed greyish pubescence hiding the black teguments, but the prothorax is yellowish red with two black macules on the central part, and the colour is not hidden by the greyish pubescence which is not so dense there as on the elytra or the under side; head with a frontal small reddish spot; abdomen reddish; head very closely aciculate and without any central frontal line; antennæ moderately long, reaching slightly beyond the shoulders, joints 4-10 triangular with the inner upper angle so acute as to give them a pectinate flabellate appearance greatly resembling that of Eletica but sharper inwardly, the ultimate joint is swollen in the centre and sharply acuminate; prothorax hardly broader than long, only slightly narrowed laterally at the apex, and having thus a somewhat parallel look, there is no distinct basal impression or longitudinal line, and the surface is deeply aciculate punctate; elytra elongated, attenuated from the base which is broader than the prothorax to the apex which is of about the same width, the outer margin is sinuated past the median part, the surface is finely aciculate, and there are no traces of costules; under side and legs finely aciculate.

From the appearance of the abdominal segments the only example I have as yet met with seems to be a female.

Length $8 \mathrm{~mm}$. ; width $2 \mathrm{~mm}$.

Hab. Cape Colony (Carnarvon).

\section{CYANEOLYTTA, gen. nov.}

Mentum one-third broader than long, transversely hexagonal, ligula triangular, dilated, truncate at the upper part, deeply grooved longitudinally in the centre, the ligular lobes long, elongate ovate, densely ciliate, maxillæ robust, the lobes greatly dilated and also densely ciliate; apical joint of palps triangular; mandibles very robust, transversely curved under the labrum and not projecting slantingly beyond it, apical inner part bluntly four-dentate at tip; labrum very broad as long as the epistome, but broader; eyes very large, reniform; antennæ long, second joint small, 4-11 greatly compressed, longer than broad, dilated at apex; prothorax nearly straight laterally from the base to two-thirds of the length, moderately attenuated thence to the apex, base straight not distinctly 
marginate, in the centre a longitudinal ímpressed line and a somewhat broad median basal impression; scutellum as broad as long, sub-ogival but somewhat rounded at apex; elytra very long, sub-parallel, but slightly ampliated at about two-thirds of the length, very little attenuated thence to the apical part, rounded at the suture and moderately divaricating there, glabrous or very briefly pubescent, the outer border plainly marginate, and the dorsal part with more or less distinct longitudinal costules; legs slender, very long; tarsi as long as or longer than the tibiæ, the joints compressed, briefly bristly underneath, claws long, greatly divaricating, cleft from apex to base; inner spur of hind tibiæ variable in shape.

The livery of the insects included in this genus is dark or light blue with a wider or lesser red patch in the centre of the metasternum. All the species are African.

In the male, the basal joint of the anterior tarsi is dilated or lobate inwardly, and the outer spur of the intermediate tibiæ dilated and laminate.

Although found on low bushes or grasses, the females are also met with going slowly along the ground somewhat in the manner of Meloë, to which their distended abdomen adds a touch of resemblance.

One of the South African species reaches British East Africa.

\section{Key to the Species.}

$\mathrm{A}^{2}$. Elytra strongly coriaceous, dorsal costæ very distinct.

B3. Basal joint of anterior tarsi of $\delta$ broadly dilated outwardly, but not lobate.

Neck as long as broad; inner spur of hind tibiæ extremely long, filiform in both sexes..

Neck longer than broad; inner spur of all tibiæ normal in both

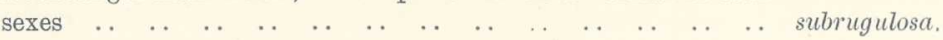

$A^{\mp}$. Elytra punctulate shagreened, dorsal costæ very faint.

$\mathrm{B}^{2}$. Basal joint of anterior tarsi of $\sigma^{3}$ produced into a long lobe inwardly.

Outer spur of intermediate tarsi of $\delta$ laminiform, obliquely truncate at apex and acuminate at tip, normal in the female; colour of upper side very dark blue or blue-black $\quad . \quad$. $\quad$. . subcoriacea.

$\mathrm{B}^{\mathrm{r}}$. Basal joint of anterior tarsi of $\delta$ moderately dilated.

Outer spur of intermediate tibiæ long and slender, and basal joint of intermediate tarsi scooped inwardly from the base to the middle in the $\delta$.

Light blue; head with a small red macule in the $q$, not in $\begin{array}{llllllllllllllll}\text { the } \delta & \ldots & \ldots & \ldots & \ldots & \ldots & \ldots & \ldots & \ldots & . & \ldots & \ldots & . & & . & \text { signifrons. }\end{array}$

Dark blue; frontal part without a red macule in either sex .. var. delagoensis. 
Cyaneolytta pectoralis, Gerst., Plate XXII., figs. 13, 13a, $13 b$ ( $q$ ).

Monatsb. Akad. Wissens., 1854, p. 695.

Peter's Reis., 1862, p. 296.

Deep dark blue, turning to lighter cyaneous on the vertical part of the head, and occasionally with a slight greenish tinge on the elytra; the antennæ and tarsi are also dark blue; head and prothorax glabrous, but not so the epistome and the labrum; the head is covered all over with deep, irregular, nearly confluent punctures, in the centre of the vertex is a fine, somewhat indistinct line which disappears towards the frontal part; prothorax one-fourth longer than broad, sub-cylindrical from the base to two-thirds of the length, attenuate thence to the apex which is distinctly marginate transversely, the margin being pubescent, the base is straight, slightly marginate; in the centre is a basal impression variable in length, and through which runs a fine impressed line which either reaches the apex or not, the whole surface is covered with closely set, deep, nearly confluent coarse punctures, leaving, however, a smooth transverse area along the outer base, above this smooth area there is occasionally a faint impression on each side; scutellum briefly pubescent: elytra scrobiculate shagreened, extremely briefly pubescent, the pubescence black, the three dorsal costæ are strongly raised and reach from the base to nearly the apex, in addition to these there is a short one divaricating on each side from the inner dorsal near the base and running for about onesixth of the length; under side and legs closely aciculate punctate, glabrous except the legs; central part of metasternum with a broadly triangular red patch. In the male the basal joint of the anterior tarsi is dilated inwardly into a sub-rectangular process hollowed laterally and filled with a spongy flavous pubescence; the intermediate and hind legs are normal in both sexes, but the inner spur of the posterior tibiæ is filiform, whitish and more than half the length of the very long basal tarsal joint. It is singular that this character should have escaped the notice of both Hagg-Rutenberg and Măklin.

Length $20-30 \mathrm{~mm}$. ; width $5 \frac{3}{4}-7 \mathrm{~mm}$.

This so-called species is so very closely related to C. granulipennis, Cast., from Upper Senegal, that I doubt if it is more than a mere varietal form. In the males of both, the distinctive external sexual characters are the same, and the shape of the genital armature is alike; in both sexes the peculiar filiform shape of the inner spur of the posterior tibiæ is also absolutely identical. The sculpture of the prothorax is less closely set in the Senegal examples than in C. pectoratis, and the elytra are slightly more rugosely punctate shagreened. I am indebted for a co-type of C. pectoralis to Professor H. J. Kolbe, of the Berlin Museum, 
Hab. Transvaal (Pietersburg, Barberton, Swaziland); Southern Rhodesia (Bulawayo, Salisbury, Enkeldoorn, Plumtree); Northern Damaraland, Ovampoland, Zanzibar, Bagamoyo, Somaliland.

Cyaneolytta subrugulosa, Mäkl., Act. Soc. Scient. Fenn., 1875, p. 456.

This species greatly resembles $C$. pectoralis, but is much inferior in size, and is at once distinguished by the normal shape of the two spurs of the hind tibiæ in both sexes. Dark blue-black or cyaneous, seemingly glabrous on the upper side, whole head scrobiculate punctate, the frontal line moderately distinct; prothorax narrower than in C. pectoralis and having thus the appearance of being more slender, closely punctate, the punctures somewhat deeper and slightly scrobiculate in some species, the smooth base, basal impression and median line as in the species above mentioned; elytra equally scrobiculate shagreened, and having each three very distinct costr: under side as in the previous species.

In the male the dilatation of the inner part of the basal joint of the fore tarsi is the same as in C.pectoralis, and the shape of the genital clasps is closely allied.

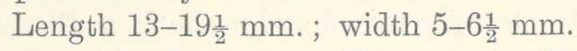

Hab. Bechuanaland (Ramoutsa); Mozambique (Lourenço-Marquez, Feira); Ovampoland.

Cyaneolytta subcoriacea, Mäkl., Act. Soc. Scient. Fenn., 1875, p. 457.

amabilis, Haag.-Rut., Deutsch. Entom. Zeitschr., 1880, p. 60.

affinis, Haag.-Rut., loc. cit., p. 60.

'Dark blue, with the elytra darker blue-black, but not uncommonly bluish green; head and prothorax glabrous; the head is of normal shape and covered with round, contiguous, smooth, somewhat small punctures ; the prothorax covered with similar punctures is as broad as long, and attenuated only at a short distance from the apex, the basal median impression is deep and the base has no smooth space; elytra very briefly pubescent, finely punctate shagreened, and having on each side three fine costules; under side with the usual sculpture and vestiture; metasternal red patch very broadly triangular.

In the male the basal joint of the anterior tarsi is produced into a long, lobate process ciliate laterally, spongy underneath, and reaching the base of the second one; the outer spur of the intermediate tarsi is long, lami- 
nate, curved at the base, dilated towards the apex and diagonally truncate there, the apex being very sharp. In the female the tarsi and the spurs are simple.

This species greatly resembles C. gigas, Fabric., from Senegambia, but differs in the sculpture of the head and prothorax, the latter being also more elongated, and in the shape of the basal joint of the anterior tarsi and of the inner spur of the intermediate tibiæ.

There can be no doubt that the Haag's and Mäklin's species are one. They vary in size and colour, but the sexual characters of the males are the same in all three.

Length 10-27 mm.; width 4-9 $\mathrm{mm}$.

Hab. Transvaal (Pretoria, Pietersburg, Waterberg, Rustenburg, Middle Limpopo); Damaraland; Ovampoland; Southern Rhodesia (Plumtree, Enkeldoorn); German East Africa.

In the examples from the Transvaal the elytra have often a greenish tinge.

Cyaneolytta signifrons, Făhr.,

Öfv. Vet. Ak. Förh., 1870, p. 353.

coelestina, Haag.-Rut., Deutsch. Entom. Zeit., 1880, p. 61.

Cyaneous blue, lighter on the elytra, clothed with a very short, but dense, appressed black pubescence, legs and antennæ very dark blue; head and prothorax covered with contiguous, deep but small foveolate punctures, in the frontal part of the former is a minute red patch altogether wanting in the male ; the prothorax is slightly longer than broad, moderately attenuate in the anterior part, plainly grooved in the centre from base to apex, the basal median impression is not very deep and the sides of the base are smooth; scutellum finely aciculate; elytra elongated, very little ampliated behind, closely and finely aciculate shagreened, and bearing each three very weak costules; metasternal red patch in the shape of a very broad, triangular macule in the male, and of a median longitudinal red line, often almost obliterated in the female. In the male the basal joint of the anterior tarsi is moderately dilated but not spongy underneath, and the inner part of the first joint of the tarsi of the intermediate legs is deeply emarginate inwardly from the base to the middle, and the outer spur is simple, long.

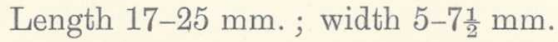

Hab. Cape Colony (Barkly West) ; Transvaal (Rustenburg) ; Bechuanaland (Kenya, Ramoutsa) ; Southern Rhodesia (Bulawayo, Salisbury, Plumtree, Enkeldoorn, Victoria Falls).

I have seen Rutenberg's type of C. coelestina. 


\section{Var. DELAGOENSIS.}

Smaller and blue-black, the pubescence on the upper side almost obliterated ; male and female without red frontal macule; the metasternal red patch broadly triangular in both sexes; the sexual characters of the male, as well as the shape of the genital clasps, are however identical.

Length $13 \mathrm{~mm}$; width $4 \mathrm{~mm}$.

Hab. Mozambique (Delagoa Bay).

\section{PSALYDOLYTTA, n. gen.}

This genus differs from Cyaneolytta and Cantharis in the extremely slender and elongated antennæ, the joints of which are almost cylindrical; the very long basal joint slightly thickened at the tip is equal in length to the third, the second, also cylindrical, is fully two-thirds of the length of the third, and the slightly tapering cylindrical ultimate joint is of the same length as the penultimate; the mentum is more than twice broader than long, and very strongly acuminate laterally in the middle, the ligula is only moderately ampliate at the anterior part, not very deeply scooped there, and the margin is set with a few setw and two very distinct, median rigid long bristles; the labial palps are very long, the penultimate is slightly longer than the ultimate which is sub-fusiform but obtuse at apex; the maxillæ are short but robust, and the inner lobe is thickly set by curved hairs at apex, the upper is very short, but the very dense long fulvous hairs with which the edge is set are describing a broad semicircle; the head is normal, but the enormously developed mandibles are produced almost horizontally backwards from the part covered by the incised labrum; elytra cylindrical, singly rounded at apex; legs and tarsi very long, the latter villose underneath, claws very distinctly cleft into two; inner spur of hind tibiæ irregularly spatulate lanciform.

The genus is proposed for Lytta lorigera, Gerst., and also for the Senegambian and other species with vaulted mandibles (flavicornis, prieuri, pilipes, \&c.). Lacordaire has already indicated (Gener. Coleopt., v., 2, 1859, p. 676) that these species, then undescribed, and also Lytta fuscicornis, Klug., should form a genus distinct from Cantharis-Lytta.

\section{Psalydolytta lorigera, Gerst.,}

Monatsb. Berl. Akad., 1854, p. 495 ; Peter's Reis., 1862, p. 295, pl. 17, fig. 10 .

Dark chocolate-brown; antennæ long, slender, joints sub-cylindrical, brick-red like the palps, the labrum, and part of the epistome ; mandibles very robust, the part uncovered by the labrum when closed is strongly deflexed backwards; head minutely punctate, clothed with a dense flaves- 
cent pubescence either covering nearly the whole head except two elongated sub-denuded longitudinal bands on each side of the frontal part, or reduced to a median frontal line on the anterior part while the sides and the vertex are narrowly marginate; prothorax extremely closely punctulate and clothed with a pubescence similar to that of the head and leaving on each side of the median part two elongated denuded bands; this pubescence is, however, occasionally restricted to the lateral and posterior margins but always forms a conspicuous longitudinal median line or narrow band extending from base to apex; scutellum with a yellow pubescence; elytra very closely punctate, clothed with a fine, nearly appressed greyish fuscous pubescence, and having along the suture a narrow flavescent or greyish flavescent line, the outer margins have a similar band reashing from the base to the rounded part of the apex, and in the discoidal part a slightly wider band reaching from the base to a very short distance from the apical margin; under side and legs clothed with a dense, appressed, flavescent pubescence hiding the teguments; tarsi densely setose, bristly laterally.

Length 22-26 mm. ; width 6-7 mm.

Hab. Mozambique (Beira); Southern Rhodesia (Umtali, Manica).

Gen. CANTHARIS, Geoffr., Hist. Ins. Env. Par., i., 1762, p. 339.

Lytta, Fabric., Syst. Entom., p. 260.

Epicauta, Redt., Faun. Austr., p. 631.

Mentum ampliate and somewhat angular laterally in the median part, ligula membranous, pubescent and deeply emarginate in the centre, labial palps short, the last one cylindrical and truncate at tip, but occasionally somewhat ampliate there; maxillæ elongated, moderately, slender, inner and upper lobes broadly and densely penicillate, the hairs long, incurved, upper lobe very distinct from the inner, truncate at apex; ultimate joint of maxillary palps cylindrical, truncate, not longer than the two preceding ones taken together; labrum as long as a rule as the epistome, covering the robust mandibles; eyes only slightly emarginate in front; antennæ either very plainly compressed or only moderately so, long, short or very short; the basal joint is either long and slightly thickened at apex or short and strongly knobby, the second joint is always short or very short, the third comparatively long, but in the species with very short antennæ it is very small, the others are usually longer than broad, but in the species with short antennæ they are broader at apex than at base, and may be almost transverse, the ultimate joint is longer than the penultimate and acuminate at tip; prothorax variable in shape, campanulate and strongly acuminate in front or sub-quadrate; scutellum sub-parallel, 
curved at apex; elytra broader than the prothorax, long, covering the abdomen, elongated in most species, converging in front or with distinct shoulders, pubescent, but occasionally glabrous, singly rounded and eithêr plainly dehiscent at apex in which case the apical abdominal segment is not entirely covered, or not; legs long, slender; the claws of all legs are either plainly cleft or only the posterior are so divided, even in one species (mesembryanthemi) they are only slightly incised at the apex.

Beauregard has endeavoured to include into the genus CantharisLytta a number of species in which, among other very secondary characters, the basal joint of the antennæ is short, clubbed at apex, the prothorax is either transverse or sub-spherical, the elytra broader than the prothorax and nearly always glabrous, and with the edges of the suture parallel. Undoubtedly some endemic South African species answer to this description, especially nitidula, flavipennis, semilineata, hurida; but amoena, suaveola, spilotella, mesembryanthemi, \&c., form passages of transition between these species, which, so far as I know, have no close allies in the other parts of Africa, and those that he includes in the genus Epicauta. I have endeavoured in vain to divide the South African ones in sections deserving to be raised to the rank of genera, except in the case of Cyaneolytta, Psalydolytta, and Prionotolytta.

Of the South African species only two, C. velata and C. strangulata, both very closely related to Senegambian and Central African forms, reach Central Africa.

We do not possess any information regarding the life-history of our species. All those I captured exude a yellow liquid through the joints of the legs and also through the mouth. They are usually met with in the spring or after summer rains, devouring the petals of flowers. C. pallidipennis is usually met with on graminaceous plants, and oftener than not in the fields of oats or barley at about the same time that the young of the crickets, Edalus marmoratus and Acrotylus deustus, make their appearance; C. nitidula on the dry, arid spots where Bobardia spathaa flowers, and where also the dry ground, sun-loving crickets, Caloptemus hamatopus and Sphingonotus, sp., generally congregate, \&c., \&c.

\section{Key to the Species.}

Finst Division.

Elytra pubescent.

$A^{2}$. Elytra plainly divaricating from each other at apex.

$\mathrm{B}^{4}$. Prothorax as broad as long, bell-shape, anterior part attenuate for about one-third of the length.

$\mathrm{C}^{4}$. Antennæ very long, joints long, narrow, sub-parallel. 
Fuscous black with the elytra chocolate brown, head rufescent with a median black transverse patch; antennæ less filiform, shorter and black; a median longitudinal band on the vertex and on the prothorax, a narrow line on the suture of the elytra and the outer margin, and a similarly narrow one on the median part of the disk ..

The same but without traces of the median dorsal white line $\begin{array}{lllllllllll}\text { on the elytra } & . & . & . & . & . . & . . & . . & . . & . . & . .\end{array}$

Body black, with only a faint greyish pubescent line along the outer margin of the elytra ..

Black, clothed with a dense greyish flavescent pubescence; head rufous, with the exception of the epistome and labrum

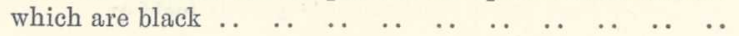

Black, clothed with a very dense sub-flavescent pubescence hiding the whole of the teguments; head rufous, epistome and labrum black

var. damarina.

ovampoa.

moesta.

rufifrons.

jucunda.

B3. Prothorax sub-quadrate, neck very short.

Antennæ moderately long, intermediate joints not twice as long as broad.

Black, body clothed with a very dense appressed, pile-like greyish pubescence; antennæ black with the three basal joints $\begin{array}{llllllllllllll}\text { rufescent } & . & \ldots & . . & . . & . . & . . & . . & \ldots & . . & \ldots & . & . .\end{array}$

The same, but the head rufescent with a broad transverse

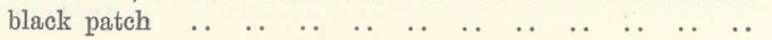

Black, clothed with a fine greyish pubescence; head rufescent with a broad, transverse black patch; elytra with a greyish line on the suture, the outer margin and the discoidal

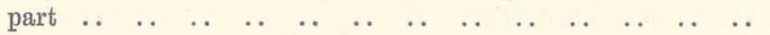

velata.

brevipennis.

var. designata.

$\mathrm{A}^{\mathrm{x}}$. Elytra singly rounded at apex but not divaricating.

$\mathrm{B}^{2}$. Prothorax longer than broad, very strongly narrowed laterally for about one-third of the length, depressed anteriorly above and sub-gibbose in the posterior part.

C3. Antennæ very long, intermediate joints twice as long as broad.

Black, thorax red; elytra black at apex and base, and also with an elongated dorsal patch, the rest of the

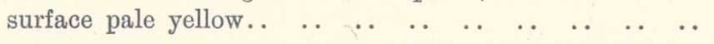

Black, clothed with a very short greyish pubescence, frontal part and prothorax red; prothorax red with two black spots; tibiæ red ..

Black, clothed with a dense appressed greyish pubescence; prothorax reddish yellow; tibiæ black $\quad . \quad \ldots \quad . . \quad$..

Black, almost glabrous; frontal part with a broad red macule; prothorax red; head closely punctate.. .. $\quad . . \quad$ bicolor.

Blue-black, glabrous; prothorax sub-scrobiculate punctate mima. 
$\mathbf{C}^{2}$. Antennæ very short, intermediate joints not compressed, very little or not longer than broad, ultimate joint acuminate as in Mylabris.

Testaceous-red with the anterior part of the head, the legs, and antennæ black; prothorax longer than wide, elongate ovate; head and prothorax glabrous, vaguely

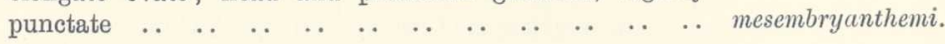

Fuscous, densely pubescent ; antennæ black ; elytra flavescent and with two broad transverse fuscous bands; prothorax almost twice as long as wide, gradually narrowed from the median part to the apex..

$B^{1}$. Prothorax not longer than broad, more or less plainly attenuated laterally in the anterior part.

$\mathrm{C}^{\mathrm{I}}$. Antennæ moderately long.

$a^{2}$. Antennæ barely reaching the shoulders.

Black, densely pubescent, pectus, tibiæ, and upper side fleshy red; head, prothorax, and especially the

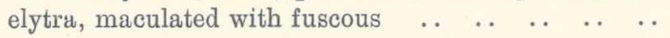

spilotella.

Black, prothorax and elytra flavescent, the former with a median discoidal patch and two small, discoidal fuscous spots ; femora flavescent; intermediate tarsal joints of forelegs triangular $\quad . \quad \ldots \quad$.

Fuscous black, densely greyish pubescent; head with two flavescent macules; elytra with one sutural, two dorsal, and one outer marginal yellow bands, some-

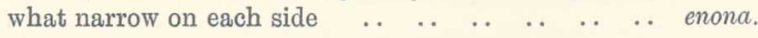

Dark green with the elytra flavo-testaceous, clothed underneath and above with a dense pubescence; head and prothorax closely aciculate.

$a^{1}$. Antennæ reaching beyond the shoulders.

Fuscous black underneath, legs, with the exception of the basal part of the femora which is black, and upper side fleshy red; clothed with a dense greyish pubescence; prothorax maculated with fuscous in the $\begin{array}{lllllllllll}\text { anterior part } & . & \ldots & \ldots & \ldots & \ldots & . & \ldots & \ldots & \ldots & \text { carneola. }\end{array}$

\section{Second Division.}

Elytra glabrous, very shiny.

Prothorax as broad as long, ampliated laterally in the anterior part; neck very short or absent.

Antennæ short, joints not flabellate nor serrate inwardly. 
A3 $^{3}$. Antennæ somewhat long, reaching beyond the shoulders, joints not compressed, ultimate one acuminate as in Mylabris.

Under side, legs, head, and prothorax bright green; elytra pale flavescent, glabrous; head and prothorax very closely punctate,

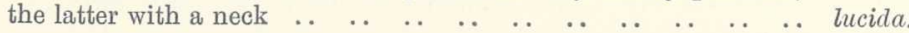

Under side and legs blue-black; elytra flavous or flavo-rufous, glabrous; head and prothorax deeply punctate, no neck .. ... pallidipennis.

$\mathrm{A}^{2}$. Antennæ not reaching beyond the shoulders.

Under side, legs, head, and prothorax bright golden-green; elytra

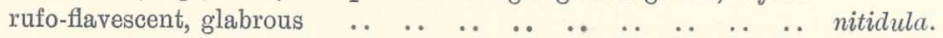

$\mathrm{A}^{\mathrm{I}}$. Antennæ not reaching the shoulders.

Under side, legs, head, and prothorax green; elytra pale flavous with a median dorsal longitudinal blue band; head and prothorax deeply and closely punctulate; elytra pale flavous, glabrous ...

semilineata.

\section{Cantharis ovampoa, Péring.,}

Ann. S. Afric. Mus., i., 1899, p. 319.

Var. C. damarina, Pér., loc. cit. iii., 1904, p. 286.

Closely resembling $C$. lorigera in shape and vestiture, but easily differentiated by the normal shape of the mandibles, and the much less filiform antennæ. Fuscous black, with the elytra chocolate-brown; head rufescent with a transverse, fuscous patch filling the greatest part of the frontal part and leaving above the epistome three reddish triangularly disposed patches; the three basal joints of the antennæ are rufescent; head closely punctulate, the punctures somewhat rugose, covered in part with a brief greyish pubescence more noticeable on the epistome and labrum, and along the median part of the vertex; prothorax narrowed anteriorly for about one-third of the length, closely, almost contiguously punctate, clothed with a very short, erect black pubescence, broadly marginated with greyish or greyish flavescent on the sides, narrowly so along the base, and having in the centre a conspicuous greyish or greyish flavescent longitudinal band reaching from base to apex; scutellum pubescent; elytra elongated, sub-cylindrical, finely and contiguously aciculate and having no traces of costules; on each side of the scutellum is a short transverse, ill-defined greyish band, the outer margin from the base to the apex of the rounded posterior part has a narrow greyish band, there is a similar one along the suture, and in the median part of the disk is another extending however in the central part only (damarina) and occasionally disappearing altogether (ovampoa).

In some examples of this species the claws are not plainly cleft.

Length $12 \frac{1}{2}-17 \frac{1}{2} \mathrm{~mm}$; width $4 \frac{1}{4}-5 \frac{1}{2} \mathrm{~mm}$.

Hab. Ovampoland; Northern Damaraland. 


\section{Cantharis moesta, Péring.,}

Trans. S. Afric. Philos. Soc., vi., 1892, p. 135.

lugubris, Pér., loc. cit. iv., 1888, p. 139 (nam. preoc.).

Black, with a moderately broad rufescent patch on each side of the vertex of the head behind the eye, outer margin of the elytra with a very narrow fringe of grey reaching from the humeral part to about the middle; upper and under sides clothed with an extremely short fuscous black pubescence; palps and antennæ black, the latter short, compressed, not filiform, intermediate joints slightly longer than wide, joints very briefly pubescent; head finely aciculate and with a faint longitudinal line; prothorax longer than broad, attenuate in front for about one-third of the length, having a median basal depression and a fine median line disappearing in the anterior part, the surface is as finely and closely aciculated as on the head, and so are the elytra which bear no traces of dorsal costules, and are singly broadly rounded at apex.

Length 9-10 mm.; width 3-4 mm.

Hab. Cape Colony (Kowie); Natal (Estcourt; Van Reenen's Pass); Southern Rhodesia (Salisbury).

Cantharis Rufifrons, Făhr., Öfv. Vet. Ak. Förh., 1870, p. 353.

Black, clothed with a greyish appressed pubescence which does not hide the colour of the background; the head, with the exception of the labrum and epistoma, is brick-red, the antennæ which are very long and with the joints sub-cylindrical have the four or five basal joints' subrufescent; vertex with a distinct median line, head aciculate punctate, the punctures not very closely set; prothorax attenuated into a neck from about one-fourth of the length, longer than broad, having in the centre a hollow median line reaching from apex to base, there is no distinct median impression in the base, the surface is covered with round, slightly rugose, contiguous punctures; scutellum pubescent; elytra elongated, sub-cylindrical covered with closely set punctures similar to those on the prothorax, no traces of longitudinal costules; under side and legs finely aciculate, abdominal segments very densely pubescent; anterior tarsi of male thickly spongy underneath, the basal joint dilated.

Length $17 \mathrm{~mm}$.; width $4 \frac{3}{4} \mathrm{~mm}$.

Hab. Transvaal (Rustenburg); Southern Rhodesia (Victoria Falls).

Cantharis jucunda, Péring.,

Trans. S. Afric. Phil. Soc., iv., 1888, p. 137.

Similar in shape and sculpture to C. rufifrons and differs only by the colour of the pubescence which is very much denser, hides completely the 
teguments, and is greyish flavescent; the vertical part of the head is somewhat more densely pubescent than the anterior. The fore tarsi of the male are as in the preceding species.

Length 14-16 mm.; width 4-5 mm.

Hab. Cape Colony (Vaal River); Transvaal; Bechuanaland (Kenya, Ramoutsa); Natal (Maritzburg).

\section{Cantharis velata; Gerst.,}

Monatsb. Berl. Acad., 1854, p. 695; Peter's Reis. n. Moss., 1862, p. 296.

Black, clothed with a dense grey pubescence hiding the integuments and turning sometimes to greyish flavescent; antennæ somewhat short, black with the three basal joints rufous, intermediate joints compressed and broad, slightly wider than long; palps sub-rufescent; head and prothorax very closely aciculate, the former with a plain median line, the latter also with a median longitudinal line and no basal depression, slightly longer than broad, and narrowed towards the apex only; elytra as closely aciculate as the prothorax, without costules, and moderately divaricating singly at apex.

Length 12-16 mm.; width 4-5 $\mathrm{mm}$.

Hab. Natal (Maritzburg, Durban, Eshowe) ; Transvaal (Pietersburg, Pretoria); Southern Rhodesia (Bulawayo); Mozambique (Feira). Ranges from Natal to Southern Somaliland.

Cantharis brevipennis, Haag., Deutsch. Entomol. Zeitschr., 1880, p. 69.

mutillata, Haag., loc. cit., p. 690.

designata, Trans. S. Afric. Phil. Soc., 1892, p. 135.

Var. albolineata, Péring., loc. cit., iv., 1888, p. 140 (nam. preoc.).

Type: In shape, sculpture and vestiture this species is almost like C. velata; it is black, and likewise thickly clothed with very dense greyish hairs; but the head is red with a very large fuscous patch invading almost the whole surface except for a narrow transverse band on the vertex and a very faint patch above the epistome; the three basal joints of the antennæ are weakly rufescent; the elytra are strongly divaricating at apex.

This type form seems to be restricted to certain parts of the Cape Colony (Enon, Grahamstown).

Var. C. designata, Péring., differs from the type form in the black patch of the head being restricted to the central frontal part only, and in the elytra having on each side a whitish grey discoidal line reaching in most cases from base to apex. In the type form the pubescence is greyish fuscous, and does not hide the integuments, the dorsal elytral 
band is very distinct, and the suture and the median line of the prothorax are also narrowly banded with greyish white, but I have since seen many examples light grey above and in which the discoidal band alone was visible, although very weakly, and had even disappeared altogether.

Hab. Transvaal (Rustenburg, Lydenburg); Southern Rhodesia (Bulawayo, Enkeldoorn, Matoppos); Ovampoland.

\section{Cantharis optata, Péring.,}

Trans. S. Afric. Philos. Soc., vi., 1892, p. 65.

Narrow, elongated; clothed with a sub-flavescent pubescence somewhat remote on the head, absent on the prothorax, very dense on the elytra; black, with the prothorax red and the elytra straw-colour and having each three black patches, the basal one rounding the shoulder and descending a little along the suture, the second one situated at about the median part of the disk is elongated, and the third one extends over the whole apical part; the antennæ are long and filiform; the head is deeply but remotely punctate and the frontal part more pubescent than the apex; the prothorax is narrowed into a long, slender neck, is deeply but remotely punctate, has a deep basal median impression, and a very short line in the centre of the disk.

Length $13 \mathrm{~mm}$; width $3 \mathrm{~mm}$.

Hab. Ovampoland.

Cantharis bistgnata, Mäkl., Öfv. Fin. Soc., xviii., 1875, p. 83.

notaticollis, Péring., Trans. S. Afric. Phil. Soc., iv., 1888, p. 138.

Black, head with a broad frontal patch extending from the epistome to the vertex; prothorax red with two small black patches in the anterior part, tibiæ reddish; antennæ long, somewhat slender, the intermediate joints more than twice longer than broad, and not much compressed; head and prothorax glabrous or nearly so, the former is somewhat closely and deeply punctured, the punctures are more remote on the prothorax which is strongly attenuated into a neck from about the median part, and has a deep, broad basal impression and a short line in the centre; elytra very finely aciculate shagreened, clothed with a very short, appressed greyish flavescent pubescence which does not however hide the colour of the background; they are only moderately divaricating at apex, and have each a very faint trace of two dorsal costules.

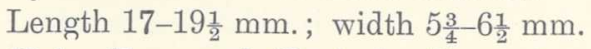

Hab. Transvaal (Pretoria, Rustenburg, Pietersburg); Cape Colony (Kimberley, Vryburg); Ovampoland. 
Cantharis strangulata, Gerst., Monatsb. Akad. Wiss. Berl., 1854, p. 695.

Peter's Reis. n. Moss., 1862, p. 295.

fulvicornis, Făhr., Öfv. Vet. Ak. Förhdl., 1870, p. 353.

Black, with a very faint blue black metallic tinge more distinct on the under side than on the upper; prothorax and pedicel of head reddish yellow; antennal joints past the three basal ones fuscous rufescent; head clothed with a brief somewhat dense greyish pubescence and sub-remotely punctulate, but the punctures are more closely set on the vertex, above the epistome is a very plain, arcuate impression; antennæ long slender, joints sub-cylindrical, and with the exception of the basal three, almost three times as long as broad; prothorax twice as long as broad, and narrowed in front into a long neck, glabrous, and bearing a few greatly remote, shallow punctures; elytra very elongated, cylindrical, not much divaricating singly at apex, very closely punctulate sub-shagreened, each puncture bearing a long, appressed greyish hair forming however only a spare pubescence, there are no traces of dorsal costules; legs and under side as pubescent as the elytra.

Length 13-17 mm.; width $3 \frac{1}{2}-4 \mathrm{~mm}$.

Hab. Cape Colony (Kimberley, Colesberg, Vaal River, Enon); Transvaal (Rustenburg, Pietersburg, Waterberg, Pretoria).

This species occurs also in Zanzibar. Owing to the courtesy of Professor H. J. Kolbe, of the Berlin Museum, I have been able to examine a co-type of Gerstäcker's species.

Cantharis bohemant, Mäkl., Öfv. Fin. Soc., xviii., 1875, p. 83.

bicolor, Făhr., Öfv. Vet. Ak. Förh., 1870, p. 353.

Black, sub-opaque, upper part of prothorax red, head with a very distinct median frontal red macule; head very briefly pubescent, and very closely and somewhat deeply punctate all over ; antennæ long, joints sub-cylindrical, somewhat compressed; prothorax very strongly narrowed laterally into a long neck from about the median part, the anterior part is also strongly depressed above, the posterior being thus almost gibbose, the base is fossulate in the centre, there is a central line from the fossule to the median part, and the surface is remotely punctate, each puncture bearing a minute black bristle; elytra elongated, coriaceous shagreened, very briefly pubescent, and the pubescence fuscous, they have no trace of costules; the under side and legs are very closely aciculate punctate, and clothed with a very brief pubescence.

Length $23 \mathrm{~mm}$; width $6 \mathrm{~mm}$.

Hab. Cape Colony (Colesberg), Transvaal (Pietersburg), Southern Rhodesia (Salisbury). 


\section{Cantharis mtma, n. sp.}

Head, antennæ, prothorax and legs black; elytra, pectus and abdomen blue-black; antennæ long, joints sub-cylindrical but slightly compressed; head briefly pubescent and, like the prothorax, shining, and closely and deeply punctate all over; prothorax very strongly narrowed laterally into a long neck from about the median part, transversely depressed above in the anterior part, sub-gibbose in the posterior, fossulate in the centre of the base and with a short but deep median line, broadly and deeply punctate, the fossule-like punctures sub-contiguous and each bearing a very short bristle; elytra elongated coriaceous, clothed with a fuscous greyish appressed pubescence; under side deeply and closely punctulate, briefly pubescent.

In colour, this species greatly resembles the dark blue species of the genus Cyaneolytta, but is at once distinguished by the shape of the prothorax, the absence of a red pectoral macule, and the normal shape of the tarsi and spurs.

Length $14 \mathrm{~mm}$. ; width $4 \mathrm{~mm}$.

Hab. Northern Damaraland.

Cantharis mesembryanthemi, Péring.,

Trans. S. Afric. Phil. Soc., iv., 1888, p. 140.

Brick-red, with the labrum and epistome, the antennæ, legs and pectus fuscous rufescent; upper side almost glabrous, except on the epistome, and shiny, under side sparingly and very briefly pubescent; legs pubescent; head with two plain impressions at the base of the frontal part, the whole of it is very sparingly and very remotely punctate, the punctures on the labrum and epistome are however deeper and much more deeply set; antennæ very short, not reaching the shoulders, the six penultimate joints are nearly as broad as long; the pedicel of the head is fuscous; prothorax longer than broad, gradually attenuate rounded laterally from the median part to the apex, without being constricted there, the median basal fossule is elongated, and the anterior part of the prothorax is plainly sloping, but not transversely impressed, and the surface is very sparingly and very remotely punctate; elytra strongly coriaceous, elongated, slightly ampliate behind, plainly singly rounded at apex, but not divaricating, and with the posterior margin somewhat broadly edged with black, the dorsal costules are not strong, but they are discernible; the under side, abdomen and legs are closely aciculate; anterior tarsi shorter than in any other South African species, from which this species differs also by the elongate-ovate prothorax. Only the claws of the hind legs are slightly cleft at the tip in the three examples which I examined. 
Length 10-11 mm.; width $3 \mathrm{~mm}$.

$H a b$. Cape Colony (Namaqualand, in the flowers of the numerous Mesembryanthemums; Hopetown).

\title{
Cantharis mashuna, Péring.,
}

\author{
Ann. S. Afric. Mus., i., 1899, p. 318.
}

Black, with the elytra light tawny flavescent, and having on each side a very broad fuscous band beginning near the basal part and reaching slightly past the median part, but not quite reaching the suture or the outer margin, and a post-median narrower yet broad band somewhat connected near the suture with the anterior band; both the upper and under sides are clothed with a very short yet dense sub-flavescent pubescence, not thick enough however to hide the teguments; head closely and finely aciculate punctate, the punctures somewhat closely set; antennæ short, and probably hardly reaching the shoulders-the antennæ of the only example I saw are mutilated, there being only 8 joints left, but the missing ones could not have been much elongated-joints 5 to 8 in the shape of an upturned transverse cone the base of which would be equal to the length; prothorax almost twice as long as broad, moderately narrowed in the anterior part for about one-fourth of the length, very plainly grooved in the median part and without any basal median impression, very closely aciculate punctate; elytra very closely aciculate and having on each side faint traces of two costules in the anterior part only; under side very closely aciculate; legs and tarsi very densely pubescent.

Length $9 \mathrm{~mm}$. ; width $3 \mathrm{~mm}$.

Hab. Southern Rhodesia (Enkeldoorn).

\section{Cantharis spilotelia, Péring.,}

Ann. S. Afric. Mus., iii., 1904, p. 286.

Fuscous black, with the frontal part of the head, a broad discoidal patch on the prothorax, a large patch on the metasternum, and the femora and tibia, with the exception of the apices which are infuscate, reddish with a fleshy tinge; elytra testaceous and sprinkled all over with irregular black spots; the whole body is covered with an appressed greyish white pubescence; head foveate-punctate, the palpi, labrum and epistome are black, and there is a frontal median black stripe reaching to about half the length of the frontal part showing a longitudinal raised area in relief; prothorax slightly longer than broad, strongly attenuate in the anterior part for about one-half of the length, grooved longitudinally from the base which is not impressed, to a short distance from the apex, irregularly and deeply punctate, and having on each side a smooth, median areolet, and another one somewhat less defined near the base ; elytra elongated, sinuate 
laterally and slightly ampliated in the posterior part, singly rounded at apex but not divaricating, and having on each, in the dorsal part, three plain costules and another less well-defined running parallel with the somewhat deplanate outer margin for the greater part of the length; they are coriaceous shagreened, and the appressed pubescence hides the background except the black spots which are glabrous; antennæ black, short, barely reaching the humeral part, joints $4-10$, in the shape of a broadly truncate cone, or nearly as broad as long.

Length $14 \mathrm{~mm}$. ; width $5 \frac{1}{2} \mathrm{~mm}$.

Hab. Transvaal (Waterberg).

\section{Cantharis elegantula, n. sp.}

Black, with the thorax flavescent and bearing a small fuscous patch in the centre of the disk, and a small fuscous dot equi-distant from the centre and the base on each side, elytra fulvous flavescent, femora except the knees flavous; head, under side and legs clothed with a short appressed silky whitish pubescence, this pubescence on the elytra is extremely short; head finely and very closely aciculate, antennæ reaching slightly beyond the humeral part, joints 3-10 triangular, apical one somewhat swollen in the centre; prothorax weakly and remotely aciculate punctate, gradually ampliate laterally, but broader by one-third at the base than at the apex, deeply grooved in the centre from end to end and with a narrow, broadly triangular impression along the base, and a deeper transverse one in the anterior part; scutellum weakly grooved in the centre, and sub-pilose; elytra elongated, the apices not singly rounded at apex, minutely punctulate, sub-coriaceous, each puncture bearing a diminutive hair; under side closely aciculate: the three median joints of the tarsi of the fore and intermediate legs are triangular, the inner part of the basal joint of the posterior ones is produced into a very plain spine (ð).

Length $10 \mathrm{~mm}$; width $3 \mathrm{~mm}$.

Hab. Cape Colony (Clanwilliam).

Cantharis enona, Péring.,

Ann. S. Afric. Mus., vol. i., 1899, p. 318.

Black, clothed with an appressed greyish flavescent pubescence, frontal part with a flavescent patch on each side, elytra with the suture, two dorsal yellow bands on each side, and the outer margin flavous; antennæ short, barely reaching the humeral part, joints, with the exception of the three basal ones, sub-conical, or nearly as broad as long; head scrobiculate punctate in the frontal part, and fossulate on the vertex, the punctures contiguous, in the centre a short, impressed longitudinal line; prothorax 
slightly longer than broad, narrowed laterally in the anterior part for about one-third of the length, slightly ampliated in the centre, deeply but narrowly grooved in the centre from the base, which is not impressed, to about two-thirds of the length, and scrobiculate-punctate as on the frontal part; elytra cylindrical, strongly shagreened and with the two dorsal bands on each side distinctly costulate, between the suture and the first discoidal band is another very fine costule which disappears beyond the median part; under side aciculate punctate, deeply pubescent; anterior tibiæ somewhat ampliated inwardly towards the apex.

Length $15 \mathrm{~mm}$. ; width $5 \frac{1}{4} \mathrm{~mm}$.

Hab. Cape Colony (Uitenhage).

\section{Cantharis carneola, Péring.,}

Trans. S. Afric. Phil. Soc., vi., 1892, p. 125.

Of a fleshy colour, but the under side with the exception of the two apical abdominal segments, the antennæ, palps and base of femora black, prothorax edged all round with black, more broadly along the anterior than along the posterior margin, and bearing also an ill-defined fuscous macule on each side, the whole body is clothed with a silky flavescent appressed pubescence; the whole head is very closely aciculate punctate, without any frontal line; prothorax ampliate rounded laterally in the centre and not produced into a neck, there is no basal depression nor traces of a longitudinal line, and the whole surface is very closely aciculate; elytra cylindrical, somewhat robust, little ampliate behind, narrowly rounded singly at apex, not costulate, and very finely aciculate punctate; antennæ reaching beyond the humeral parts, joints $5-10$ longer than broad, of an inverted cone shape; hind femora thickened ( $\lesssim$ ).

Length $13 \mathrm{~mm}$.; width $5 \mathrm{~mm}$.

Hab. Cape Colony (Namaqualand).

\section{Cantharis amoena, Péring.,}

\section{Trans. S. Afric. Phil. Soc., vi., 1892, p. 126.}

Dark green, with the antennæ black and the elytra flavescent rufescent, under and upper sides clothed with a dense appressed greyish pubescence; antennæ very short, not reaching the humeral part, joints almost quadrate ; head closely aciculate, and having a not very distinct, small smooth patch on the anterior part of the frons; prothorax of the same shape as that of C. semilineata, and very closely punctulate, the central part is more or less distinctly furrowed longitudinally; elytra elongated, sub-cylindrical, punctate shagreened, briefly but very densely pubescent, and without any 
traces of dorsal costules; under side closely aciculate; anterior tarsi moderately long.

Length $7 \frac{1}{2}-8 \mathrm{~mm}$.; width $3 \mathrm{~mm}$.

Hab. Cape Colony (Namaqualand).

Cantharis LuCida, Haag-Rut.,

Deutsch. Entom. Zeit., xxiv., 1880, p. 65.

Bright emerald-green, elytra bright straw-colour, antennæ and palpi black, tarsi cyaneous; clothed except on the elytra which are glabrous, with a fine, greyish flavescent pubescence, only moderately dense, and erect on the head and prothorax; antennæ long, reaching beyond the shoulders, joints nearly twice as long as broad, slightly compressed; head. and prothorax deeply and closely punctate, the former has a frontal impression and a deeply impressed line from there to the epistome; prothorax slightly longer than broad, very slightly wider in the centre than at the base, attenuated gradually from near the central part to the apex which is half the width of the base, in the centre of the disk is an elongated ovate impression and none at the base; elytra elongated, subcylindrical, only moderately singly rounded at apex, weakly coriaceous, and each with a very slight, often indistinct discoidal longitudinal raised line; under side and legs closely aciculate; outer spur of hind tibiæ thickened, truncate at tip.

Length 11-15 mm.; width 4-5 mm.

Hab. Cape Colony (Cape Town, Stellenbosch, Paarl, Ceres, Worcester, Knysna).

\section{Cantharis palimipennis, Haag-Rut.,} Plate XXII., figs. 14, 14a, $14 b$.

Deutsch. Entomol. Zeitschr., 1880, p. 66.

Very dark cyaneous, antennæ and palps black; elytra flavescent red glabrous, the other parts of the body clothed with a fuscous pubescence; antennæ reaching the shoulders but not beyond it, joints slightly attenuate at the base, about twice as long as broad at apex; head deeply and closely pitted and having a short, frontal, weakly impressed line; prothorax distinctly broader at a short distance from the apex than at the base, deeply and closely punctate, and having in the centre a short deeply impressed line, and occasionally a narrow, elongated impression; elytra elongated, sub-cylindrical, sub-coriaceous and with fine irregularly disposed and remote punctures, on each side are two plain discoidal costules, and occasionally a third supra-marginal one is discernible ; under side and legs 
very closely aciculate; outer spur of hind tibia long and as sharp as the inner one.

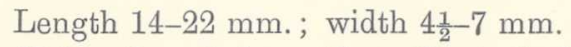

Hab. Cape Colony (Cape Town, Stellenbosch, Paarl, Malmesbury).

\author{
Cantharis nitidula, Fabric., \\ Plate XXII., figs. 6, 6a. \\ Syst. Entom. Append., p. 820.
}

Green, briefly pubescent, with often a golden tinge on the prothorax, elytra glabrous, testaceous with a fleshy tinge; palps and antennæ black, the latter do not reach beyond the shoulders, and the short joints, which are sub-turbinate, are as broad at the top as long; head very sparsely punctulate and having a long frontal impressed line reaching from the top of the vertex, which is slightly fossulate, to the epistome; prothorax very sparsely pubescent, ampliate rounded laterally at a very short distance from the apex and sinuate above the basal part, it is sparsely punctulate like the head and has in the centre a longitudinally elongated, very plain impression ; elytra elongated, sub-cylindrical, moderately singly rounded at apex, sub-coriaceous but not punctulate, and having no traces of dorsal costules; under side finely aciculate; anterior tarsal joints short, sub-turbinate, intermediate and posterior little elongated; inner spur of hind tibiæ long and as sharp as the inner at tip.

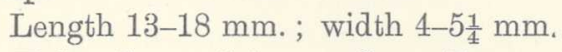

Hab. Cape Colony (Cape Town, Stellenbosch, Paarl, Riversdale, Caledon).

Cantharis semilineata, Haag-Rut.,

Berl. Ent. Zeitschr., 1880, p. 67.

mera, Péring., Ann. S. Afric. Mus., i., 1899, p. 318.

Dark metallic blue turning to dark green on the head and prothorax, elytra pale yellow with a dark fuscous, moderately broad discoidal band reaching from near the base to a short distance from the apex, and with the suture and the outer, but not the posterior, margin very narrowly edged with fuscous; under side, head and prothorax clothed with a long; not appressed greyish and black pubescence; elytra glabrous; antennæ short not reaching quite the humeral part, joints slightly longer than wide, not compressed, ultimate one very acuminate at the tip; head covered with deep contiguous punctures, and having on the frontal part, above the epistome, a moderately deep impression, epistome and labrum dark blue; prothorax as broad as long, hardly attenuate in the anterior part and slightly ampliate there laterally, in the centre of the disk is a very 
distinct impression, the surface is covered with punctures similar to those of the head, and equally closely set; scutellum pubescent; elytra glabrous except for a few setulose hairs on the sides of the shoulders, and a fringe of setæ along the outer margin, very finely aciculate but not coriaceous, and without any visible traces of dorsal costules; under side and legs closely aciculate punctate; anterior tarsi long; spurs of hind tibiæ both very short, but sharp.

Length 8-9 mm.; width $3 \frac{1}{2} \mathrm{~mm}$.

Hab. Cape Colony (Clanwilliam).

Gen. SITARIS, Latr., Plate XXII., fig. 9.

Hist. Nat. Crust. and Insect., x., p. 402.

Mentum long, somewhat narrow, ligula very deeply incised in the centre, almost bi-lobate on that account, labial palpi short, the palpigers very long; maxillæ not very robust, inner lobe narrow, upper dilated, hairy ; maxillary palps of moderate length, the last joint very little longer than broad, occasionally fused with the penultimate, sub-truncate at tip; mandibles robust, strongly falciform, the right one sinuate inwardly, and sharp; labrum transverse, short, epistome reaching beyond the insertion of the antennæ; head deflexed, sub-vertical, broadening on the vertex, neck somewhat long, eyes large, not very broad, but long; antennæ with the first joint knobby, the second small or very small, the third as long as the two preceding ones taken together, in the $\delta$, the following joints are nearly equal in length to the third, not compressed but not cylindrical; in the $q$ they are distinctly shorter, and only half the length of the third; prothorax transverse, sub-quadrate, depressed; scutellum very broad, and very long, rounded at apex; elytra considerably broader at the base than the prothorax with the shoulders rounded, very deeply sinuate outwardly at about one-third of the length, the inner part strongly divaricating at or near the scutellary region and strongly attenuated thence to the apex, leaving the greatest part of the abdominal segments covered by the wings only; metasternum strongly developed; legs somewhat short, the hind femora more robust than the others, outer spurs of the posterior tibiæ thick, dilated at tip, more so in the $q$ than in the $\delta$, scooped inwardly and either sub-truncate or acuminate outwardly at apex, claws broadly divaricating, upper part pectinate, lower filiform.

This genus is easily distinguished from its congeners by the broadly divaricating elytra, which are gradually attenuated in the inner part from near the scutellary region down to the apex.

Two species, very distinct from each other, are recorded from the South African area. 


\section{Sitaris capensis, Péring.,}

Trans. S. Afric. Phil. Soc., iv., 1886, p. 141.

Testaceous red, moderately shiny; elytra punctulate, yellowish with the median part of the suture, the outer margin from some distance from the base to the apex, where it broadens considerably, and a humeral narrow band obliquely directed towards the median dorsal part infuscate; antennæ with the exception of the two basal joints which are red, knees, hind tibiæ and tarsi fuscous black; body densely pubescent, especially the under part. Head deflexed, rugose, and with a deep impression in the centre; prothorax slightly broader than long, slightly ampliated laterally towards the median part, very little narrower at apex than at base, deeply impressed transversely on the median part of the disk, and with a shallow median impression above the centre of the base; it is sparsely punctate ; scutellum punctate and pubescent, deeply impressed in the centre of the base; elytra broader than the prothorax and three times as long, with the humeral angles very prominent, slightly sinuate laterally in the middle and greatly diverging at the suture from the median part to the apex, which is reduced to one-fourth of the width of the base; they are finely rugose and very briefly pubescent, and have each one discoidal longitudinal raised line; under side finely aciculate punctate, the meso- and metasternum are marginated with black.

Length $12 \mathrm{~mm}$. ; lat. $4 \frac{1}{2} \mathrm{~mm}$.

I found my first example of this species close to the nest of a bee belonging to the genus Anthophora.

Hab. Cape Colony (Malmesbury).

\section{Sitaris notaticollis, Péring.,}

Trans. S. Afric. Philos. Soc., iv., 1886, p. 141.

Plate XXII., fig. 9.

Black, with the prothorax, elytra, and abdomenl light yellow; prothorax with two black macules on the disk, apex of elytra black; body covered with a flavescent pubescence short on the prothorax and elytra, longer on the head and especially denser on the under part of the body and on the legs. Head very rugose, separated from the epistome by a transverse impression, in the centre of the vertex is a shiny patch; antennæ black, the joints moderately robust, not compressed yet not cylindrical; prothorax as broad as long with the base and apex nearly equal in width, somewhat ampliated laterally in the anterior part; deeply bi-impressed longitudinally in the centre, and also deeply but irregularly and not very closely punctate; scutellum black, scabrose punctate, apex smooth, shiny; elytra divaricating inwardly from the scutellary region to the apex where they are singly sharply acuminate, and very deeply 
sinuosely emarginate from a third of the length; they are finely coriaceous, and have no distinct traces of discoidal raised lines; under side closely aciculate punctate.

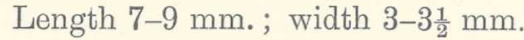

Cape Colony (Grahamstown).

\section{Tribe ZONITINI.}

\section{Key to the Genera.}

$\mathrm{A}^{2}$. Prothorax strongly campanulate.

$\mathrm{B}^{2}$. Upper part of the claws pectinate.

Maxillæ moderately robust, upper lobe short; body glabrous,

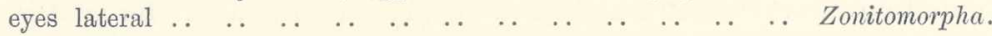

Maxillæ slender, upper lobe long, penicillate, body briefly pubescent, eyes sub-contiguous beneath $\ldots \ldots \ldots c \ldots$ Zonitoschema.

$\mathrm{B}^{\mathrm{r}}$. Upper part of the claws not pectinate.

Maxillæ very slender, upper one with a long pencil of hairs;

body densely pubescent; eyes lateral, elongated . . . . Iselma.

$A^{x}$. Prothorax transverse or only slightly campanulate.

B. Upper part of the claws pectinate.

Head produced into a long triangle; upper lobe of maxillæ very long, corneous, briefly hairy inwardly only, but ending in a fine pencil of hairs $\ldots \begin{array}{lllllllllll} & \ldots & \ldots & \ldots & \ldots & \ldots & \ldots & \ldots & \ldots & \ldots\end{array}$

Zonitodema.

Head produced into a short triangle; upper lobe developed into a very long filiform process the whole surface of which is covered $\begin{array}{lllllllllllll}\text { with short hairs } & \ldots & \ldots & \ldots & \ldots & \ldots & \ldots & \ldots & \ldots & \ldots & \ldots & \ldots & \text { Nemognatha. }\end{array}$

\section{ZONITOMORPHA, n. gen. Plate XXII., fig. $7 a$.}

Mentum hexagonal, as broad as long, ligula very short with the membrane lining it very long, deeply-scooped $\mathbf{V}$-shape in the centre and fringed there with a short, erect pubescence; labial palps moderately long, the ultimate joint truncate at the tip; maxillæ somewhat robust, the inner lobe densely hairy, the upper one densely penicillate, some of the hairs are stiff and bristle-like; maxillary palps like the labial, distinctly long ; mandibles very long, arcuate and sharp at tip, projecting much beyond the labrum which is truncate at apex, as long as the epistome, and ciliate pubescent at the tip; head much longer than broad, truncate behind, with the posterior angles well defined and provided with a long neck; eyes reniform but broadly separated on the upper and on the under sides; antennæ 
long, reaching to about the median part of the elytra, compressed, serrate inwardly except the two basal and the apical one; prothorax tapering gradually from the base to the apex where it is less than half the width of the latter which is marginate ; scutellum very broadly triangular, obtusely truncate at apex ; elytra one-third broader than the base of the prothorax, rounded at the shoulders, elongated, sinuate laterally at about one-third of the length, somewhat ampliate past the sinuation, rounded at apex and not divaricating there, moderately convex; legs and tarsi only moderately slender, spurs of tibiæ somewhat short and of nearly the same size, claws long, greatly divaricating, the upper part weakly pectinate, the lower equally long but very slender, almost filiform.

The facies is not unlike that of Stenodera, but it differs by the shape of the antennæ.

\section{Key to the Species.}

$\mathrm{A}^{2}$. Elytra somewhat ampliated past the middle.

$\mathrm{B}^{2}$. Prothorax punctate, the punctures deep, nearly contiguous.

Elytra with a broad transverse median black band .. $\quad . \quad \ldots \quad . . \quad$ sellata.

$\mathrm{A}^{\mathrm{I}}$. Elytra not distinctly ampliated past the middle.

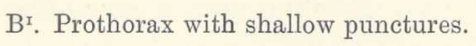

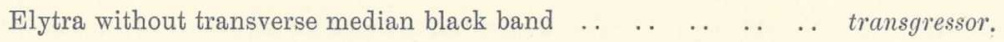

Zonitomorpha seluata, Făhr., Öfv. Vet. Akad. Förhandl., 1870, p. 354.

Very briefly pubescent, yet shiny; testaceous yellow with the mandibles at apex, the palps, the antennæ, a broad transverse band situated slightly in front of the median part and reaching from side to side, and the sternum black; the femora are fuscous at base and apex, so are the knees and the apex of the tibiæ; the tarsi are wholly fuscous; head very closely and somewhat deeply punctate, but less so in the middle of the vertex; prothorax longer than broad, attenuate towards the apex where it is only half as wide as the base, slightly sinuate laterally towards the middle, moderately convex on the posterior part, depressed on each side of the anterior part, closely but not sub-contiguously punctate, very faintly canaliculated longitudinally and having a more distinct impression in the centre above the base; scutellum slightly infuscate; elytra slightly sinuate towards the median part, somewhat ampliate thence, very little attenuate towards the apex, rounded there, the posterior part plainly convex, deeply and irregularly punctate, almost shagreened on the transverse black band, the punctures closely set; under side finely aciculate punctate; antennæ reaching beyond the median part of the elytra, opaque 
except the two basal joints which are shiny, and have occasionally the first joint rufescent, the intermediate compressed joints, which are twice as long as broad or more, are strongly angular inwardly at tip.

I have seen examples in which the transverse black band of the elytra is entirely wanting.

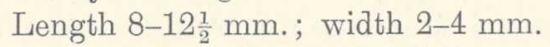

Hab. Natal (Durban, Maritzburg); Transvaal (Pretoria, Waterberg, Zoutpansberg); Southern Rhodesia (Salisbury).

\section{Zonitomorpha transgressor, Péring.,}

Ann. S. Afric. Mus., i., 1899, p. 319.

Very briefly pubescent, yet shiny; palps, antennæ, with the exception of the two basal joints which are yellow rufescent, meso- and metasternum, apex of femora and tibiæ, and the whole tarsi black; head closely and deeply punctate, parallel, slightly longer than broad, sinuate towards the middle with the posterior angles straight and prominent, antennæ reaching the median part of the elytra, compressed, the joints broad, distinctly angular inwardly ; prothorax truncate at each end, somewhat conical, broader at the base than at the apex by one-third, closely punctulate, very briefly pubescent, and having in the centre an elongated longitudinal impression which does not reach either the apex or the base; scutellum closely punctulate, rounded at apex; elytra oblong, double the width of the prothorax in the anterior part, three times as long, slightly sinuate behind the humeral part, not distinctiy ampliate laterally past the middle, jointly rounded at apex, moderately convex on the upper side, closely and deeply punctate, but less deeply so in the posterior part, and having on each side three distinct costules reaching from the base to the apex; under side of the body briefly greyish pubescent; legs somewhat long, finely punctulate.

Length $14 \mathrm{~mm}$.; width $5 \frac{1}{4} \mathrm{~mm}$.

Resembles a little examples of $Z$. sellata without transverse black band on the elytra, but the antennæ are somewhat shorter, and the joints wider.

Hab. Southern Rhodesia (Bulawayo).

\section{ZONITOSCHEMA, n. gen., Plate XXII., fig. $8 a$.}

Closely allied to Zonitomorpha, but differs in the shape of the maxillæ which are narrower and more elongated, and bear at apex a longer pencil of hairs ; the eyes, which are more granular, are less broadly separated on the upper side, and are sub-contiguous on the under side; the antennæ are very long and very slender, the intermediate joints being slightly 
arcuate; the elytra are cylindrical; the legs are somewhat more slender; the upper part of the claw is also pectinate and the lower filiform.

Differentiated from Zonitomorpha by the greater development of the eyes above and their sub-contiguity beneath, as well as by the shape of the antennæ.

Key to the Species.

$\mathrm{A}^{2}$. Elytra without black markings.

$\mathrm{B}^{2}$. Prothorax very narrowly attenuate in front.

Head and prothorax pale flavescent; elytra fleshy pink .. . coccinea.

Head and prothorax pale flavescent, elytra pale straw-colour,

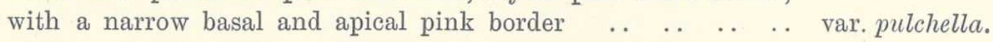

Head and prothorax pale flavescent; elytra entirely very pale

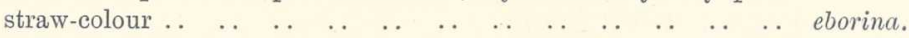

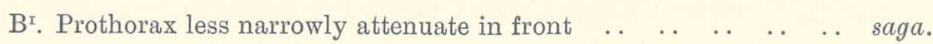

$\mathrm{A}^{\mathrm{r}}$. Elytra with a black band.

Pale yellow on the upper side, elytra black from past the middle to

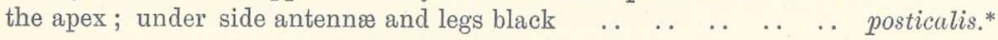

\section{Zonitoschema coccinea, Fabr., Plate XXII., fig. 8.}

System. Eleuth., ii., p. 77 ; Fairm., Ann. Soc. Ent. Fr., 1891, p. 264. suaveola, Péring., Ann. S. Afric. Mus., i., 1899, p. 320.

Pale flavous, with the elytra pink or fleshy pink, antennæ deep fuscous with the exception of the first joint which is flavous, apex of mandibles, knees, tibiæ and tarsi fuscous black; body extremely briefly pubescent on the upper and under sides; head deeply and somewhat closely punctate all over, the labrum less so, shiny; prothorax also shiny and with the punctures nearly similar to those on the head but a little more closely set; it is longer than broad, attenuate laterally from near the median part to the apex, and nearly linear from the median to the base, only moderately convex from the middle to the transversely carinate base over the centre of which is a shallow depression; scutellum closely punctulate; elytra finely aciculate punctate with the punctures contiguous, cylindrical, and having on each side two very fine not always distinct dorsal longitudinal raised lines; under side and legs very finely and closely

* Zonitis tenuicollis, Fabric., which Kolbe mentions as occurring also in Natal ("Die Kaf. Deutsch. Ost.-Afrikas," p. 262), is unknown to me. It may, however, be identical with one of the species here described, in which case it will have to be included in this genus. 
aciculate punctate and clothed with a slightly longer pubescence. The antennæ are as long as the whole body.

Length $11 \frac{1}{2} \mathrm{~mm}$.; width $3 \mathrm{~mm}$.

Hab. Southern Rhodesia (Mazoë).

I am not certain that my examples are Fabricius' Lytta coccinea, in which case the name suaveola will be retained.

Var. yulchella, Pér.,

Trans. S. Afric. Philos. Soc., vi., 1892, p. 126.

Similar to the type form from which it differs in the coloration of the elytra, which are very pale flavescent with a somewhat narrow red band along the base, and a narrower one along the apical margin.

Length $13 \mathrm{~mm}$.; width $4 \mathrm{~mm}$.

Hab. Natal (Durban); Cape Colony (Port St. John).

Zonitoschema eborina, Hăhr., Ofv. Vet. Akad. Förhandl., 1870, p. 354.

Shape of the preceding species. The vestiture is also the same, but the head and prothorax are more finely and somewhat more closely punctulate, but the punctuation of the elytra is however the same as in $Z$. coccinea; the head and prothorax have a flavescent tinge, and the elytra are very pale flavescent, almost flavescent white, without any trace of narrow red border at the base or at the apex; antennæ not quite as long as the body but nearly so, black with the basal joint flavescent; palps, knees, tibiæ, and tarsi black.

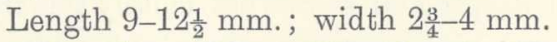

Hab. Cape Colony (Uitenhage); Natal (Durban); Transvaal (Rustenburg).

Zonitoschema saga, Péring.,

Ann. S. Afric. Mus., i., 1899, p. 320.

This species is so closely allied to $Z$. eborina that I took it at first to be identical. It is however distinguished by the still briefer pubescence of the elytra, and especially by the shape of the prothorax which is less acuminate at apex than that of $Z$. eborina. I have however seen as yet one example only of this species.

Length $14 \mathrm{~mm}$; width $4 \frac{1}{2} \mathrm{~mm}$.

Hah. Cape Colony (Worcester Distr.). 
Zonitoschema posticalis, Péring.,

Trans. S. Afric. Phil. Soc., vi., 1892, p. 135.

apicalis, Pér. (nam. preoc.), loc. cit., iv., 1886, p. 142.

Body clothed with a very short flavescent pubescence; head, prothorax, elytra from the base to two-thirds of the length yellow, the remainder of the latter black; under side except the two apical abdominal segments which are yellow, palps and legs black; all antennal joints, the labrum and mandibles fuscous black; head deeply punctate, especially in the frontal part, the punctures not set very close and leaving in the centre of the forehead a narrow longitudinal smooth space; prothorax strongly attenuate in the anterior part for about one-third of the length, slightly yet distinctly sinuate thence towards the base which is broader than the median part, covered with moderately shallow punctures separated by an interval nearly equal to their own diameter, narrowly impressed longitudinally in the centre, and transversely along the carinate base; scutellum ciosely punctate; elytra impressed laterally at the base above the shoulder, straight, not distinctly sinuate laterally, not much convex, and covered with somewhat deep punctures separated by a very narrow interval; the suture is slightly raised and there are on each side two slightly raised lines which disappear in the posterior part; under side and legs very closely aciculate punctate, and more densely pubescent than on the upper side.

Length $20 \frac{1}{2} \mathrm{~mm}$; width $5 \mathrm{~mm}$.

Hab. I am not sure that this insect is a native of South Africa. It was given to me long ago, and I did not record the locality at the time, perhaps because it was not indicated.

Gen. ISELMA, Haag-Rut., Plate XXII., fig. $11 a$.

Deutsch. Entom. Zeitsch., xxiii., 1879, p. 402.

Mentum longer than broad, sub-ovoid laterally, the ligular part is completely fused with the mentum, very strongly attenuate, parallel, nearly half the length of the mentum proper, slightly emarginate at apex and translucid; the labial palps are set close together on the outer face and separated by a narrow, sub-carinate process bearing two stiff setulose bristles, outer face of the mentum deeply pitted, slightly impressed in the centre; labial palps of normal length, the joints nearly equal in length, sub-cylindrical, ultimate one truncate; maxillæ very long and slender, inner lobe with the suture almost obliterated and weakly pubescent, upper lobe sub-cylindrical, lined inwardly and at the top with a very long pubescence; maxillary palps very long, sub-compressed, ultimate one truncate at tip; head greatly elongated and narrow, as long 
as the prothorax and provided with a long neck, parallel from the vertex to the epistome, the eyes ovate, not reniform, epistome shorter than the labrum which is slightly attenuate, mandibles very long, slightly tapering and hooked at tip; antennæ very long, slender, joints sub-cylindrical, occasionally angular inwardly at tip, ultimate joint longer than the penultimate; prothorax longer or as long as broad, strongly tapering in the anterior part, ovate globose in the posterior; scutellum long, oblong; elytra broader than the prothorax, elongated, sub-cylindrical, but occasionally plane on the dorsal part (planidorsis), not singly rounded at apex, without costules, always pubescent; last abdominal segment of $\widehat{\sigma}$ deeply scooped; legs long, tarsi also long, bristly laterally, claws corneous, each one very deeply cleft as in Cantharis, and likewise not pectinate; spurs of hind tibiæ either contiguous or not at the base, equally long or the inner one longer, sometimes one or both are sub-spatulate or truncate diagonally and sharp at apex.

The species included in this genus have not been recorded from beyond the South African limit. They are mostly found in the western part of the Cape Colony, but one species is recorded from the eastern provinces. They are floricolous, and appear for a short time only. Nothing is known of their habits.

$\mathrm{A}^{2}$. Elytra sub-cylindrical.

\section{Key to the Species.}

B3. Hind spurs not connected at the base, of nearly equal length and not ampliate at apex.

Black, clothed with a dense black pubescence; antennæ filiform; prothorax with contiguous fossulate punctures, and with a short median raised line.

Elytra not acuminate behind; spurs straight $\ldots \begin{array}{llllll}\text {.. } & \text {. } & \text {.. } & \text {.. } & \text { ursus. }\end{array}$

Elytra acuminate behind, inner spur oblique towards the tip .. hirsuta.

$\mathrm{B}^{2}$. Hind spurs connected at the base, and of equal length, not ampliate at apex.

Cs. Antennæ sub-serrate.

Black, with the elytra purplish red, and a very broad, infuscate sutural band; prothorax with a distinctly raised median line rufipennis.

Black, with the elytra red; prothorax with a median elongated

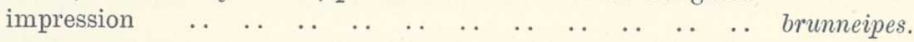

$\mathrm{C}^{2}$. Antennæ not sub-serrate.

Black, with the elytra pale testaceous, almost pale strawcolour.

Prothorax roughly punctate ..

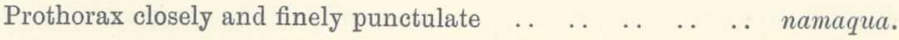




\section{$\mathrm{C}^{\mathrm{I}}$. Antennæ serrate.}

Black, with the elytra brownish red, very densely greyish pubescent; prothorax nearly as broad as long, strongly attenuate laterally in front, straight from the median part

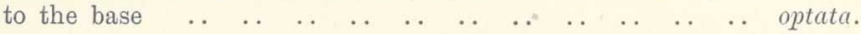

$\mathrm{B}^{\mathrm{r}}$. Hind spurs contiguous at the base, inner one longer than the outer.

Black, with the elytra and legs very pale flavescent; inner spur

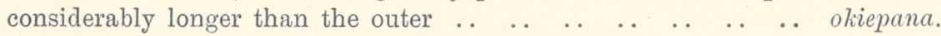

Dark green, turning sometimes to dark blue, clothed with a black pubescence, both spurs long, contiguous and obliquely truncate

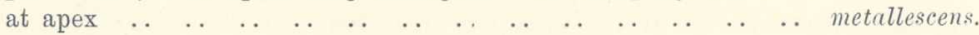

Black, with the elytra purplish red, elothed with a blackish and

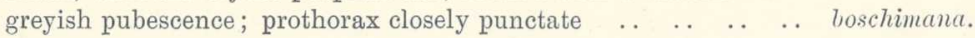

Black, with the elytra purplish or pale red and clothed with a black and greyish pubescence; prothorax finely and closely

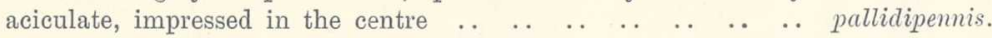

Black, with the elytra pale red, clothed with a very dense greyish pubescence; prothorax finely and closely aciculate, not impressed $\begin{array}{llllllllllllll}\text { in the centre } & . . & \ldots & \ldots & \ldots & . & \ldots & \ldots & . . & \ldots & \ldots & . & . . & \text { rubripennis. }\end{array}$

$A^{1}$. Elytra depressed on the dorsal part.

B. Hind spurs quite free, of equal length, ampliate before the apex, and sharp there.

Black, with the elytra ænescent; clothed all over with a dense, erect pubescence

planidorsis.

\section{ISELMA URSUS, Thunb.,}

Dissert. nov. spec. Insect., vi., 1789, p. 107; Billb., Mon. Myl., 1813, p. 73 ;

Haag-Rut., Deutsch. Entom. Zeitschr., xxiii., 1879, p. 403.

Black, shiny, clothed with a long black pubescence, erect on the head and prothorax, more appressed on the elytra; antennæ long, filiform, joints sub-cylindrical but slightly compressed; head covered with contiguous aciculate punctures; prothorax ampliate ovate, gradually attenuated into a neck, very convex, covered with sub-scrobiculate, contiguous punctures, and having in the centre of the disk a median, sub-carinate line; scutellum closely punctulate; elytra elongated, weakly sinuate laterally, slightly ampliate behind and covered with deep foveolate punctures, somewhat unequal and separated by a narrow wall; under side very closely aciculate; legs very pubescent; hind spurs somewhat whitish, of nearly equal length, free and sharp at tip.

Length 10-13 mm.; width $3 \frac{1}{2}-5 \mathrm{~mm}$.

Hab. Cape Colony (Namaqualand). 
IseLma HIRsuta, Thunb.,

Dissert. nov. spec. Insect., vi., 1789, p. 107; Haag-Rut., Deutsch. Entom. Zeitschr., 1879, p. 404.

Closely allied to what I take to be I. ursus, Thunb., but éasily distinguished from the latter by the elytra being attenuate behind towards the apex. It is completely black and also densely hairy, the hairs on the head and prothorax being erect and very long, but the punctures although equally deep are less rugose, owing to the narrow wall separating them being less raised, the median raised line is wanting, there is a not very distinct elongated impression on each side of the central discoidal part, and the punctures of the elytra are finer but equally closely set. In my examples of $I$. ursus the hind spurs are somewhat short and straight; whereas in this species they are sub-contiguous at the base, divaricating; and oblique towards the apex which is sharp.

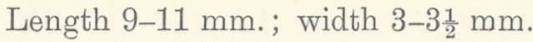

Hab. Cape Colony (Worcester).

Iselma Rufipennis, Haag-Rut.,

Deutsch. Entom. Zeitschr., 1879, p. 406.

cribraria, Péring., Trans. S. Afric. Phil. Soc, iv., 1888, p. 142.

Black, clothed with a long, dense black pubescence longer and erect on the head and prothorax, elytra purplish red with a somewhat fuscous broad sutural band; antennæ long, sub-serrate inwardly; head covered all over with round, deep, somewhat irregular punctures separated by a narrow, slightly raised interval; prothorax elongate ovate, greatly attenuated in front, covered with deep foveolate punctures, impressed on each side of the hind part of the disk, and having in the centre a plainly carinulate longitudinal line reaching neither apex nor base; elytra subcylindrical, not ampliated behind, closely coriaceous shagreened, briefly pubescent except at the base and along the sutural part where the hairs are erect; under side closely aciculate; hind spurs soldered at the base, cleft from about the median part of the length, the two points of equal length.

Males captured in September flying round a bush (Rhus) not in flower.

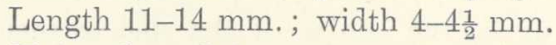

Hab. Cape Colony (Cape Division).

Iselma BRunNeIPes, Haag-Rut.,

Plate XXII., figs. 11, $11 a$.

Deutsch. Entom. Zeitschr., 1879, p. 405.

Allied to the preceding species; the shape is the same; the colour is black with the elytra red or slightly purplish red all over; the antennæ 
are also sub-serrate; the head and prothorax are covered with long, black, erect hairs, and the head is closely and irregularly punctured; the prothorax however is slightly less ampliate ovate, the punctuation differs in being more regular and less rugose, the lateral discoidal impressions are indistinct, and so is the longitudinal raised line, which, when sufficiently distinct, is reduced to a mere streak; the elytra are slightly less coriaceous shagreened; the hind spurs are soldered at the base, cleft frum about the median part, the inner point is slightly longer than the outer and stouter.

Length $11 \frac{1}{2}-13 \frac{3}{4} \mathrm{~mm}$; width $4-4 \frac{1}{2} \mathrm{~mm}$.

Hab. Cape Colony (Namaqualand).

Iselma fLAvipennis, Haag-Rut., Deutsch. Entom. Zeitschr., 1879, p. 404

Black, with the eiytra light flavescent testaceous, almost straw-colour ; clothed with black hairs longer and more erect on the head and prothorax, and also very abundant on the elytra; intermediate antennal joints not sub-serrate, but slightly angular inwardly at apex; head closely and roughly punctate on the frontal part, and more finely and regularly so on the vertex; prothorax elongate ovate, slightly less attenuated in front than the preceding species, scrobiculate, very convex and having in the centre a not always very distinct impression; elytra moderately ampliate laterally in the posterior part, very closely punctate, but not distinctly coriaceous or shagreened; under side closely punctulate; hind spurs scooped at apex, the inner angle thicker and slightly longer than the outer.

Length $10-12 \frac{1}{2} \mathrm{~mm}$; width $4 \frac{1}{2}-5 \frac{1}{2} \mathrm{~mm}$.

Hab. Cape Colony (Namaqualand, Specktakel).

My examples were compared with Haag-Rutenberg's type.

\section{IsELMa NAMAQUA, n. sp.}

This species might at first sight be mistaken for I. flavipennis, of which it has the colour and shape, being likewise black with the elytra very pale testaceous, and clothed with black hairs; the difference however is in the sculpture of the prothorax which instead of being scrobiculate is covered with round, moderately deep punctures without highly raised walls, the median impression is distinct, and there is in front and behind this impression a slightly raised longitudinal line; elytra very closely punctate and somewhat coriaceous laterally; hind spurs soldered, cleft at the tip, the two spines sharp and of equal width and length.

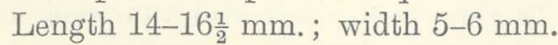

Hab. Cape Colony (Namaqualand). 
IsELMA ортATA, n. sp.

Black, with the elytra brick-red, clothed with a greyish flavescent pubescence on the elytra and on the under side, and long greyish and black hairs on the head and prothorax; antennal joints strongly serrate inwardly; head and prothorax deeply scrobiculate punctate, the pubescence on both being longer and denser than in the other species; prothorax as broad as long, ampliate rounded laterally at about the median part, triangularly attenuate thence to the apex, and bearing in the centre a longitudinal raised line; elytra sub-cylindrical, slightly broader at the base than at the apex, deeply and closely punctate and not distinctly coriaceous; under side aciculate; spurs seemingly free near the base, diverging towards the apex, both of same length and thickness, and equally sharp at tip.

Length $12 \mathrm{~mm}$, ; width $4 \frac{1}{2} \mathrm{~mm}$.

Hab. Cape Colony (Grahamstown).

\section{IsElma okiepana, n. sp.}

Black, with the legs and even the tarsi flavescent and the elytra pale flavous, covered with a greyish flavescent pubescence, black, however, and longer and erect on the head and prothorax; antennæ filiform; head covered with deep, contiguous, equal punctures; prothorax ovate not strongly attenuate in the anterior part, and covered with deep, closely set slightly irregularly disposed punctures separated by a narrow wall; in addition to the black erect hairs there is also a fine flavescent subappressed pubescence which is also noticeable on the head, and in the centre of the convex disc is a longitudinal raised line obliterated at both ends; elytra closely punctate, each puncture bearing a flavescent hair on the dorsal part adjoining the suture, and a black one laterally and behind; under side closely aciculate, briefly pubescent; hind spurs very long, either fused for the greatest part of the length, or free, the inner one obliquely truncate, much longer than the outer, and both sharp at tip.

Distinguished from I. flavipennis and I. namaqua by the more filiform antennæ, the colour of the legs, the prothorax less attenuated in front, and the shape of the hind spurs.

Length $7 \mathrm{~mm}$. ; width $3 \mathrm{~mm}$.

Hab. Cape Colony (Namaqualand).

\section{Iselma metalLescens, n. sp.}

Metallic dark blue, almost black on the head and prothorax and turning blue or dark greenish on the elytra; antennæ and palps black; the whole body is clothed with a very long, erect and sub-erect black pubescence, that on the tibiæ is fulvescent; antennæ long, filiform; head 
and prothorax sub-scrobiculate punctate, the punctures deep, the latter is ampliate ovate, only moderately attenuate in front, slightly bi-impressed on the disk, and having sometimes there a third, median impression; elytra sub-parallel, closely shagreened punctate; under side aciculate; hind spurs fairly long, of equal length and obliquely acuminated from about the median part to the tip.

This species is easily distinguished from the other species of the genus, except I. planidorsis, by its metallic colour; and from the last-named species, which is also metallic, by the non-depressed elytra.

Length 7-9 $\frac{1}{2} \mathrm{~mm}$. ; width $2 \frac{1}{4}-3 \mathrm{~mm}$.

Hab. Cape Colony (Clanwilliam, Worcester).

\section{IsELMA BOSCHIMANA, n. sp.}

Black, with the elytra purplish red; upper and under sides clothed with black pubescence not mixed with greyish or flavescent hairs; antennæ not sub-serrate; head and prothorax clothed with long, erect black hairs, and both covered with round, not rugose punctures not contiguous but nearly so; the prothorax is ampliate ovate but very distinctly attenuated in the anterior part, there is an impression on each side of the convex part of the disk, and occasionally a somewhat faint central one; elytra elongated, sub-cylindrical, coriaceous shagreened; hind spurs joined from the base to about the median part, both acute, inner one longer than the outer.

Length 7-9 mm.; width $2 \frac{1}{2}-3 \mathrm{~mm}$.

Hab. Cape Colony (Clanwilliam).

IseLma Rubripennis, Cast.,

Hist. Nat. d. Ins., ii., 1840, p. 276.

rubripennis, Haag-Rut., Deuts. Entom. Zeitschr., 1879, p. 406.

Shape and size of I. boschimana; black, the elytra red with a slight tinge of brown; the pubescence, especially on the elytra, is plainly flavescent; the erect black setulose hairs on the head and prothorax are mixed with greyish flavescent ones; the prothorax is quite globose and covered with small round punctures almost contiguous but separated from each other by a thin wall; the elytra are elongated, sub-cylindrical, deeply and closely punctate, not coriaceous; inner spur of hind tibiæ much longer than the outer, and sharp.

This species is closely allied to I. boschimana, and also to I. pallidipennis, it differs from the former in the punctures of the prothorax, being narrower and more shallow; in I. pallidipennis the punctuation is finely aciculate. 
The late Clem. Muller compared my examples of this species with HaagRutenberg's type, and I have ascertained in Paris that Castelnau's species is identical with Haag-Rutenberg's species.

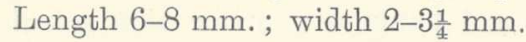

Hub. Cape Colony (neighbourhood of Cape Town).

Iselma paldidipennis, Haag-Rut.,

Deuts. Entom. Zeitschr., 1879, p. 406.

erythoptera, id. ibid., p. 407.

It is very difficult to discriminate between this species and the preceding one, the difference consisting merely in the finer and more aciculate punctuation of the prothorax; the elytra are pale brick-red with a greyish pubescence with which are black hairs intermixed, or redder brown with the pubescence more flavescent (erythroptera); the sculpture is that of I. rubripennis; the inner spur of the hind tibiæ, which is longer than the outer, is however more dilated, but this character varies.

Length 7-11 mm.; width 3-5 mm.

Hab. Cape Colony (Namaqualand).

\section{IsELma PLANIDorsis, n. sp.}

Black, elytra with a greyish bronze tinge; body very thickly pubescent, the pubescence is appressed but mixed with it are black setulose hairs, erect and very long on the head, prothorax, and elytra; antennæ long, joints compressed; head and prothorax closely punctate, the punctures rugose; prothorax elongated, sub-ovate, moderately attenuated in front, not very convex, the flavescent appressed pubescence forms a more distinct longitudinal line in the centre from base to apex; elytra parallel but with the dorsal part depressed, their sculpture is the same as that of the prothorax, and they have thus a punctate shagreened appearance; under side deeply aciculate punctate ; the hind spurs are of equal length, ampliated in an elongate spatulate form at some distance from the base and acuminate at the tip.

Length $11-11 \frac{1}{2} \mathrm{~mm}$. ; width $3 \frac{1}{2} \mathrm{~mm}$.

Hab. Cape Colony (Clanwilliam).

\section{ZONITODEMA, n. gen., Plate XXII., figs. 10a, $10 b$.}

Mentum longer than broad, ampliate angulate laterally in the centre ligula as broad as the apex of the mentum and with the suture distinct, parallel, deeply and sub-triangularly incised in the anterior part for about 
half the length, maxillæ very long and very slender, inner lobe with an apical inner fringe of short hairs, upper lobe as long as the maxillæ, compressed, slender, fringed with hairs, ending in a long pencil of hairs, and either slightly longer, including the pencil of hairs, than the maxillary palps, or very much longer; maxillary palps very long, the ultimate joint sub-cylindrical or sub-fusiform, truncate at the tip; mandibles long, arcuate at the tip ; labrum very long, elongate ovate, epistome transverse, arcuate in front, eyes large, lateral, head plainly quadrate behind the eyes; antennæ shorter than the body, moderately slender, all the joints sub-cylindrical, and of nearly equal length, even the second basal one which is not nodose; prothorax sub-quadrate or rounded laterally and attenuate in front, base distinctly marginate; scutellum moderately small, obtusely triangular; elytra sub-parallel, slightly sinuate laterally, or somewhat attenuate behind; legs and tarsi long, slender ; claws cleft into two, upper tooth moderately arcuate, strongly pectinate inwardly, lower claw filiform; inner spur of hind tibiæ short but robust.

The genus is characterised by the extremely long upper lobe of the maxillæ, which is always longer than the maxillary palps, is briefly hairy, penicillate at apex and greatly resembles in some species that of Nemognatha and Gnathium.

The type of this genus is Zonitodema viridipennis, Fabr. and Casteln. But I am not sure of the absolute identity of this species, and were it to prove erroneous $Z$. fahrai (collaris, Făhr.) would be the type.

\section{Key to the Species.}

$\mathrm{A}^{2}$. Body black, with the prothorax reddish or red; elytra green or blue.

$B^{2}$. Abdominal segments partly red ( $\delta$ ) or totally red ( $q$ ).

Inner lobe of maxillæ, including the apical pencil of hairs, one-third longer than the maxillary palps; prothorax transverse, sub-

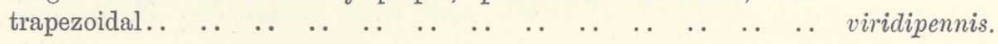

Inner lobe of maxillæ slightly longer than the maxillary palps; prothorax ampliate rounded laterally, slightly attenuate in front parentalis.

Inner lobe of maxillæ twice as long as the maxillary palps; prothorax ampliate rounded laterally, plainly attenuate in front .. fahrei.

$\mathrm{B}^{\mathrm{I}}$. Abdominal segments not red.

Inner lobe of maxillæ hardly longer than the maxillary palps; prothorax ampliate rounded in the centre, not much attenuate in

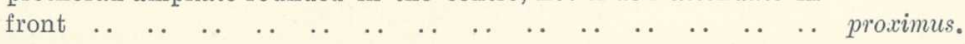

$\mathrm{A}^{\mathrm{x}}$. Body rufous, with the elytra green.

Inner lobe of the maxillæ longer than the somewhat short palps; prothorax not attenuate in front.. 
Zonitodema viRIDIPennis, Fabric., Plate XXII., figs. 10, 10a, $10 b$.

Entom. Syst. Suppl., p. 103; Casteln., Hist. Nat. d. Ins., ii., p. 276.

Black, with the legs fuscous and the tarsi sub-rufescent; prothorax red, elytra metallic green; labrum and epistome sub-rufescent; abdomen with the three abdominal apical segments pale red in the male, all the segments red in the female; head triangular, strongly elongate acuminate, very briefly pubescent, but setulose on the long, ovate labrum, the surface is covered with irregular punctures somewhat scrobiculate in front and closely set, and in the centre of the frontal part is a smooth, raised line or patch, neck closely punctulate; prothorax somewhat transverse, slightly ampliate rounded laterally in the middle, as broad or very nearly so at the apex the angles of which are rounded as at the base, moderately convex on the disk, weakly and sub-remotely punctulate and glabrous ; scutellum bluntly triangular; elytra elongated, slightly sinuate laterally towards the median part, non-costulate, coriaceous shagreened, and clothed with a very fine greyish pubescence; underside and legs finely aciculate, very briefly pubescent; occasionally the pectus bears an ill-defined rufescent median patch. The upper maxillary lobe is somewhat compressed, hollowed inwardly, as long as the maxillary palps, glabrous, and bears at the tip a pencil of hairs two-thirds its own length.

Length 6-11 mm.; width $2 \frac{1}{4}-4 \frac{1}{2} \mathrm{~mm}$.

Hab. Cape Colony (Cape Town, Stellenbosch, Worcester, Paarl, Ceres, Malmesbury, King Williamstown); Transvaal (Bocksburg, Pietersburg, Pretoria, Lydenburg, Potchefstroom).

\section{ZoNitodema PARENTALIs, n. sp.}

Very similar to the preceding species from which it differs in the shape of the prothorax which is slightly longer than broad, and attenuate, although moderately so in front, and thus resembles $Z$. fahrceii, from which it can be distinguished by the upper lobe of the maxillæ which is shaped like that of $Z$. viridipennis, and which with its pencil of hairs is not as long as the head; the sculpture, colour, and vestiture are the same as in $Z$. viridipennis.

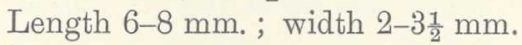

Hab. Cape Colony (Port Elizabeth); Natal (Frere); Transvaal (no exact locality).

\section{ZONITODEMA FAHRÆI.}

collaris, Făhr., Öfv. Ak. Förhd., 1870, p. 355 (name preoccupied).

Shape, size, and sculpture of $Z$. viridipennis; the colour is also the same, that is to say black with the prothorax yellowish red and the elytra 
green, but turning occasionally to blue; the pubescence covering the latter is, however, less dense and shorter, but the distinctive character of this species is the very great length of the upper maxillary lobe which is nearly two-thirds the length of the whole antennæ, is very briefly hairy and bears at apex a sharp pencil of hairs equal only to one-fifth of its length. But for the pencil of hairs continuing it, this lobe would be like that of Nemognatha or Gnathium, the latter an American genus.

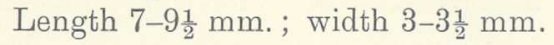

Hab. Bechuanaland (Mafeking); Southern Rhodesia (Salisbury, Plumtree, Manica).

\section{Zonitodema proxima, Péring.,}

Trans. S. Afric. Phil. Soc., vi., 1892, p. 126.

Black, with the prothorax pale red, and the elytra almost black but with a greenish tinge; palps and maxillæ slightly rufescent, apical joint of maxillary palps more broadly truncate at apex than the other species, upper lobe of maxillæ somewhat broad, flattened, and with the peneil of hairs included, slightly longer than the palps; head very briefly pubescent, deeply punctate, the punctures closely set, sub-rugose, a faint smooth patch in the frontal part; prothorax sub-ampliate, rounded laterally, slightly attenuate in front, sparsely punctulate with the punctures shallow, glabrous; scutellum very briefly pubescent; elytra punctate shagreened, very briefly pubescent, the pubescence greyish white; under side closely aciculate and briefly pubescent like the legs; all the abdominal segments black.

Length 6-8 mm.; width $1 \frac{1}{2}-2 \frac{1}{2} \mathrm{~mm}$.

Hab. Natal (Eshowe); Transvaal (Lydenburg).

\section{Zonitodema Ruficeps, Péring.,}

Trans. S. Afric. Phil. Soc., iv., 1888, p. 143.

Head, prothorax, scutellum, under side, legs and palps red, antennæ black with the basal joint red, elytra metallic green ; maxillary upper lobe compressed, somewhat broad, longer by itself than the maxillary palps and ending in a short pencil of hairs; head deeply and closely punctate, the punctures only slightly rugose, in the frontal part a distinct raised line; prothorax transverse, moderately rounded laterally towards the apex, but not attenuate, less sparingly punctate than in the other species of the genus; scutellum very briefly pubescent; elytra finely coriaceous shagreened, distinctly clothed with a greyish white pubescence; under side and legs very briefly pubescent.

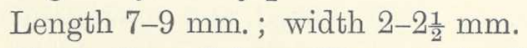

Hab. Cape Colony (Namaqualand). 


$$
\begin{gathered}
\text { Gen. NEMOGNATHA, Illig., } \\
\text { Plate XXII., figs. } 12 a, 12 b \text {. } \\
\text { Magaz., vi., 1807, p. } 333 .
\end{gathered}
$$

Mentum sub-quadrate, slightly rounded; ligula free, also rounded laterally; mandibles long, straight, arcuate at apex; labrum as broad as long, maxillæ very weak, upper lobe filiform, very long, projecting considerably beyond the apex of the mandibles; palps somewhat long, last joint of both labial and maxillary sub-fusiform, truncate at tip; head triangular, eyes large, reniform; antennæ long, joints compressed, the second basal one knobby, one-third shorter than the joint following; prothorax short, transverse, slightly ampliate rounded laterally; scutellum longer than broad, triangular, blunt at apex; elytra parallel, not much wider than the prothorax, sinuate laterally, somewhat depressed on the discoidal part, singly rounded behind, coriaceous or shagreened; legs long, tarsi longer than the tibiæ; claws cleft from apex to base, upper hook somewhat robust, closely pectinate, lower hook very slender, simple; spurs short, slender; last abdominal segment of $\widehat{\alpha}$ broadly scooped.

\section{Key to the Species.}

$\mathrm{A}^{2}$. Maxillary lobe not longer than the head.

B. Elytra with a dorsal costule on each side; abdomen totally red or with

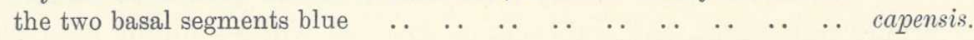

Elytra not distinctly costulate.

Abdomen with the three apical segments or the centre of the ante-

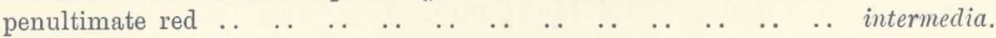

$\mathrm{A}^{\mathrm{x}}$. Maxillary lobe as long as the head and thorax together.

Abdomen totally red ..

Nemognatha capensis, sp. $n$.

Plate XXII., figs. 12, $12 a, 12 b$.

Metallic dark blue on the upper side, turning to greenish on the pectus; all the abdominal segments red; antennæ and tarsi black; body with an extremely short pubescence; the whole head is covered with deep, slightly rugose, contiguous punctures separated by a very narrow wall; upper lobe of maxillæ projecting beyond the maxillæ to a distance equal in length to that of the head; the neck is robust and as closely punctate at the head; prothorax transverse, being slightly broader than long, slightly ampliate rounded laterally, covered with deep, sub-contiguous rugulose punctures broader than those on the head, and having in the centre a longitudinal median impression with a narrow line in it running 
from the base to about the median part of the disk; scutellum and elytra punctulate shagreened, and bearing each a distinct discoidal costule running from the base to past the median part where it vanishes, and also a much less distinct, juxta-sutural one beginning at some distance from the base and slightly shorter than the discoidal; under side finely aciculate, the aciculate punctures less closely set on the pectus than on the abdomen.

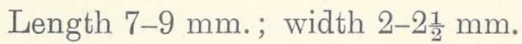

Hab. Cape Colony (Worcester, Stellenbosch, Ceres, King Williams town).

\section{Nemognatha intermedia, $\mathrm{n} . \mathrm{sp}$.}

The differences between this species and the preceding ones are very slight; the punctures on the head and prothorax are deeper and still more closely set; the prothorax is plainly more ampliated laterally in the anterior part; the elytra are alike, but the three or four apical abdominal segments are red, and the fourth is even occasionally greenish blue laterally; maxillary lobe shorter than the head.

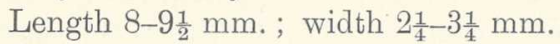

Hab. Cape Colony (King Williamstown); Transvaal (Pretoria, Waterberg, Zoutpansberg).

\section{Nemognatha meraca, n. sp.}

Dark greenish blue, briefly pubescent; the whole abdomen pale red, or occasionally with the sides of the basal one greenish blue; head closely punctate, but the punctures instead of being rugulose as in the two preceding species are smooth and not quite contiguous; the maxillary lobe is greatly elongated, being quite as long as the head and prothorax taken together; in shape the prothorax is like that of $N$. capensis, that is to say slightly ampliate rounded laterally; a little in front of the median part, it has likewise a median depression from the middle to the base, and the customary transverse impression in front of the depression is moderately plain, but the punctures are round, smooth, and separated by an interval about equal to their diameter; elytra finely coriaceous subshagreened and without traces of any distinct costules, except in the anterior part; under side closely aciculate.

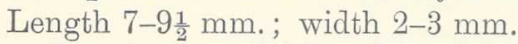

Hab. Mozambique (Rikatla). 


\section{ADDITIONS.}

\section{Mylabris amplectens, Gerst.,}

Arch. f. Naturgesch., vol. 37; Decken's Reis. Gliederth., 1873, p. 207, pl. x., fig. 9 .

Black, the elytra very dark chestnut brown, with the humeral part and the edge of the suture chestnut or rufous brown; whole body covered with a silky flavescent dense pubescence, appressed and somewhat shorter on the elytra ; antennæ bright yellow with the four basal joints distinctly piceous black. Head irregularly but very slightly impressed, and very closely punctulate, the punctures smooth; prothorax more than usually narrowed in front, very closely but somewhat irregularly punctate, the pubescence long, the intermixed black hairs more or less erect ; scutellum punctate, densely pubescent at the base; elytra elongated, finely reticulate, sub-shagreened, median dorsal costate more evident than the others ; in the base is a broad arcuate dorsal lunule beginning at the suture, and broadly joined under the shoulder with a lateral marginal band; slightly above the median part is a very narrow transverse yellow band reaching from side to side, slightly wider at the outer margin than at the suture, and a post-median of the same colour, and of nearly equal width, but with the two edges slightly bi-sinuate; claws rufescent.

Easily distinguished from the other South African species with the four basal joints of antennæ black, by the two narrow posterior bands of the elytra and the connection of the basal dorsal patch with the lateral.

Length $13 \mathrm{~mm}$.; width $4 \frac{1}{2} \mathrm{~mm}$.

Hab. Mozambique.

This species occurs in British and German East Africa. In the type the antennæ have the three basal joints only black, and my examples from Amani are like that, whereas in my Mozambique example the four basal joints are of that colour.

\section{DESCRIPTION OF TWO LARVÆ.}

I have met with two larvæ of Meloidæ which differ so much in several characters, and one of them in mode of life, from what is hitherto known, that their description may prove of interest, although their identity cannot be ascertained. 


\section{Larva A. ? Mylabris.}

Body pale flavescent. Head broad, anterior frontal part. with a triangular grooved area the apex of which reaches past the centre, and nearly meets there another inverted triangle obtuse at apex, and somewhat in the shape of a scutellum; clypeal part broadly transverse, and bearing several longitudinal grooves with raised intervals, the suture separating it from the frontal part is very distinct, and above that suture are two short, stiff setæ; the labrum is broad, sub-quadrate, but deeply sinuate in the centre of the apical margin, and covers the well-developed falcate mandibles ; the maxillary and labial palps are thick with the apical joint very small, and as if planted in the centre of the preceding one, that of the maxillary is not very distinctly bi-articulate; the antennæ are almost like the palps, but a little longer, and seemingly four-jointed, and there are three convex ocelli set in a longitudinal line, the apical nearly touching the base of the antennæ; prothoracic ring, rigid, smooth above, meso- and metathoracic wrinkled, folded above and laterally and hardly distinguishable from the abdominal segments; all the elliptical tracheal openings very distinct; behind the tracheal opening is a slight swelling bearing a short seta; the $3-6$ ventral segments and also the ultimate one have on each side a conspicuous swelling greatly resembling the pseudo-Jegs of caterpillars, with a longitudinal ovate elongate opening the inner margin of which is fringed with twelve acute chitinous hooks bent outwardly, and each of these false legs bear from two to four rigid setæ; the four-jointed short legs end in a moderately sharp, little incurved claw, and the posterior are slightly shorter than the others; the body is glabrous except for the few rigid setæ mentioned, but on the very finely aciculate dorsal part each segment, including the thoracic ones, has a supra-lateral, smooth, raised stigma bearing a very short hair, and a similar one, almost lateral and situated near the hind border of the segment.

Length $13 \mathrm{~mm}$.; width $5 \mathrm{~mm}$.

This larva was blown by a gale of wind from the ever-shifting sand dunes in the neighbourhood of Cape Town. The only wasps noticed there belong to a species of Bembex.

The presence of the ocelli point clearly to it being the second larval form, or Caraboid larva, of a Meloid going probably to turn into the Scarabæoid larva. Its size, however, is such that it can hardly be that of a Cantharid or Zonitid of the kinds occurring in that locality. I doubt if it can be that of a Meloe, because the larvæ of the different species of this genus known are not provided with the abdominal false legs. But the second instar or metamorphosis of the species of the genus Mylabris 
is not known, and it is therefore probable that this larva belongs to the genus, as probably also does the following one.

\section{LARVA B}

Body black, legs reddish brown; median dorsal part of the three rigid thoracic rings pale flavescent, prothorax with four black dots, two on each side of the median part, mesothorax with two marginal spots on each side of the median part; metathorax with four similar spots but with a longitudinal median black band of the same colour, and a sharp keel in the posterior part. Head not broader than the prothorax, greatly retracted, and with the typical triangle in the anterior part; the clypeus is narrower than in larva $\mathrm{A}$ and not pluri-grooved longitudinally; the labrum is similar; the antennæ are hardly distinct and show as a membranaceous cavity in which is imbedded a very short joint; the three ocelli are less in a straight line than in larva $\mathrm{A}$; the three thoracic segments are corneous and rigid; the four-jointed legs are robust, more so than in larva A, and the ungulate claw is stouter and more curved; the orifices of the false legs are transverse and fringed with seriate, dark sub-compressed claws hooked outwardly and resembling cat-claws, they number from twentyeight to thirty, and are more numerous on the upper margin, where they are continued inwardly, than on the lower. The body is glabrous, the prosternum and coxæ have a single rigid seta on each side, and the raised hair-bearing areas on the upper side of the segments are not visible.

This larva was dry and much contracted when I found it. It had emerged from the case of a ground-loving Psychid moth brought to me in a cardboard box. The presence of the ocelli show also that it is a second instar, or Caraboid larva. The shape of the orifices of the false legs and the disposition and number of the claws edging them are very different from those of larva A. It is also smaller, measuring only $9 \mathrm{~mm}$. in length and $5 \mathrm{~mm}$. in width.

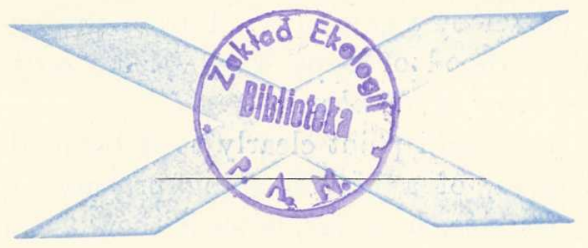




\section{BIBLIOGRAPHY.}

Bertoloni, G.

Illustratio rerum naturalium Mozambic., x., 1849, p. 381-434. 3 col. pls.

Billberg, G. J.

Monographia Mylabridum. Holmiæ, 1813, 8vo, 74 pp. 5 col. pls.

Brandt, J., and ERICHson, W. F.

Monographia generis Meloë. Nov., Act. Acad. Leopold, 1832, xvi., pp. 101-142. 1 pl.

Castelnad, Laporte de.

Histoire naturelle et iconographique des Coléoptères. Paris, ii., 1840 (1835-1840, 4 vols., $8 \mathrm{vo}$ ).

Erickson, W. F.

Beiträg zur Insecten-Fauna von Angola in besonderer Bezichung zur geographischen Verbeitung der Insecten in Afrika. Wiegman's Archiv. d. Naturg., ix., 1843, pp. 197-267.

Fabricius, J. C.

Systema Eleutheratorum secundum ordines, genera species; adjectis synonymis, locis, observationibus, descriptionibus. Kiliæ, 1801, 2 vols.

Supplementum Entomologiæ systematicæ. Hafniæ, 1798, 8vo, 574 pp.

FăHRæus, O. T.

Coleoptera Caffrariæ, annis 1838-1845, a J. A. Wahlberg collecta. Heteromera. Öfvers. Kongl. Vetensk. Akad. Förhandl., 1870, No. 4, p. 243-35̌8.

Fairinatre, L,

Enumération des Coléoptères recueillis par M. le Dr. Hans Schinz dans le sud de l'Afrique. Ann. Soc. Ent. Franc., 1888, p. 198.

GeER, C. DE.

Mémoires pour servir à l'histoire des Insectes, vii., 1778 (vols. i.-vii., 1752-1778, $4^{\circ}$ ).

Geistaeker, C. E. A.

Diagnosen der von Peters in Mossambique gesammelten Käfer u Hymenoptera Ber. Verhandl. Akad. Berl., 1855, 17 pp. Peter's Reis., 1862, pp. 268-526. 8 col. pls.

Guérin-Méneville.

Iconographie du régne animal de G. Cuvier, ou représentation d'après nature de l'une des espèces les plus remarquables et souvent non encore figurées de chaque genre d'animaux etc. Paris, 1829-1844, 7 vols. 450 pls. Insectes, vii., 1829-1843.

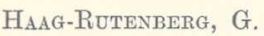

Beiträge zur kenntniss der Canthariden. Deutsch. Entom. Zeitsch., 24, 1880, pp. 16-90.

Herbst, J. F. W.

Natursystem aller bekanten in-und auslandischen Insecten. Berlin, 1785-1806 (20 vols.). Käfer, i.-x., 1785-1806.

ILLiger, J. C. W.

Magazin für Insectenkunde. Braunschweig, 8, vi., 1807 (vols. 1-6, 1802-1807).

KoLBE, H. J.

Coleopteren aus Africa. Stettin. Entom. Zeit., 1894, pp. 178-190.

Die Käfer Deutsch.-Ost. Afrikas. Berlin, 1897, 368 pp. 4 pls. 
LACORDAIRE, T.

Histoire naturelle des Insectes. Genera des Coléoptères ou exposé méthodique de l'étude de tous les genres proposés jusqu'ici dans cet ordre d'Insectes. Paris, 1854-1876, 12 vols. Atlas. 134 pls.

Latreille, P. A.

Histoire naturelle, générale et particuliere des Crustacés et des Insectes, х., 1804, 411 pp. 8 pls.

Leach, W. E.

An Essay on the British species of the genus Meloë, with descriptions of two exotic species. Trans. Lin. Soc. Lond., xi., 1815, pp. 35-49. 2 col. pls.

Lichtenstein, A. A. H.

Catalogus musei zoologici ditissimi Hamburgi III., Feb., auctionis lege distrahendi. Hamburg, 1796, 8vo, $222 \mathrm{pp}$. Tom. tertius. Insecta.

LINNÉ, C. von.

Systema naturæ per regna tria naturæ secundum classes, etc., ed. decim. reformata. Holmiæ, 1758-59.

MäKLIN.

Neue Mordelliden. Canthariden, Cisteliden. Oefv. Fin. Soc., xviii., 1875.

Marseul.

Monographie des Mylabrides d'Europe. L'Abeille, vol. vii., 1870, pp. 1--205̃.

Monographie des Mylabrides. Mém. Soc. Roy. Liège, 1872, pp. 361-663. 6 pls.

Olivier, A. G.

Entomologie ou Histoire naturelle des Insectes, \&c. Coléoptères, iii. (6 vols. 1789-1808).

Péringuet, L.

Second Contribution to the South African Coleopterous Fauna. Trans. S. Afr. Philos. Soc., iv., 1888, pp. 67-194. 4 pls.

Third and Fourth Contributions to the South African Coleopterous Fauna. Trans. S. Afric. Philos. Soc., vi., 1892, pp. 1-136.

Fifth Contribution to the South African Coleopterous Fauna. Ann. S. Afric. Mus., i., 1899, pp. 246-330. 2 pls.

Sixth Contribution to the South African Coleopterous Fauna. Ann. S. Afric. Mus., iii., pp. 167-300. 1 pl.

Redtenbacher, L.

Fauna austriaca. Die Käfer, nach der analytischen Methode bearbeitet. Wien., 1849, pp. 907, 2 pls.

Thunberg, C. P.

Dissertatio Entomologica novas insectorum species sistens. Upsaliæ, 1781-1791, 130 pp. 5 pls.

Vorgts, H.

Zur Synonymie der Meloiden-Gattung Zonabris. Wien. Entomol. Zeit., xxi., 1902, pp. $177-78$.

Zur Kenntniss der exotischen Arten der Meloiden Gattung Zonabris Har. Wien. Entomol. Zeit, xx., 1901, pp. 215-218.

Nicht Zonabris Har., sonden Mylabris Fab. Allgem. Zeitschr. fur Entomologie, 1903, pp. 234-239.

WULFEN, F. X. voN.

Descriptiones quorundam Capensium Insectorum (Coleopt. Lepid.). Erlangæ, 1786, $4^{\circ}, 40$ pp. 2 col. pls. 


\section{N D E X}

A

Āctenodia

adamantina (Decatoma)

affinis (Cyaneolytta)

africana (Decatoma)

africana (Decatoma)...

alholineata (Cantharis)........

aliena (Ceroctis)

alterna (Mylabris)

amabilis (Cyaneolytta)

amatonga (Mylabris)...

americana (Decatoma)

amoena (Actenodia)

amoena (Cantharis) ....

amplectens (Mylabris)

angulatus (Meloë)

apicalis (Coryna)

apicalis (Zonitoschema)

apicipustulata (Coryna)

argentata (Coryna)

\section{B}

basibicincta (Mylabris)

bicincta (Mylabris)

bicolor (Cantharis)

binotata (Prionotolytta)

bipartita (Mylabris)

bipunctata (Ceroctis).

bisignata (Cantharis)

bizonata (Mylabris)

bivittata (Ceroctis)

blanda (Ceroctis)

bohemani (Cantharis)

bohemani (Ceroctis)

boschimana (Iselma)

brevipennis (Cantharis

brunneipes (Iselma)

buqueti (Mylabris).

burmeisteri (Mylabris)

C

caffer (Meloë) .

172

cafra (Decatoma)

221,224

Cantharinit

173,244

Cantharis

208,210

capensis (Ceroctis)

..... 288

capensis (Nemognatha).

271
PAGE

cardinalis (Eletica) ............... 245, 247

carneola (Cantharis)................ 258, 267

catenata (Decatoma)................. 221, 223

Ceroctis ............................... 207

chrysomelina (Actenodia) ......... 239, 241

cichorii (Decatoma) ....................... 225

cinctuta (Coryna) ....................... 234, 236

coccinea (Zonitoschema) .................. 275

coeca (Mylabris)...................... 184, 202

colestina (Cyaneolytta)..................... 253

connexa (Mylabris) ................. 181, 194

contorta (Decatoma) ............... 222, 230

Coryna …................................ 234

cribraria (Iselma) ......................... 280

curtula (Actenodia) .................. 239, 240

Cyaneolytta .............................. 249

\section{D}

damarina (Cantharis) .............. 257, 259

Decatoma .................................. 221

decemguttata (Actenodia)............. 239, 240

duodecimguttata (Coryna) ............... 238

decipiens (Decatoma)....................... 230

delagoensis (Cyaneolytta) ......... 250, 254

dentata (Mylabris) .................. 184, 204

derepta (Decatoma) ......................... 224

derosa (Mylabris) .................... 183, 200

designata (Cantharis) ............... 257, 261

dicincta (Mylabris) ................. 181, 196

digressa (Decatoma) ................. 222, 226

discrepans (Actenodia) ............... 239, 241

disputabilis (Decatoma ) ............ 222, 226

distincta (Coryna) ..................... 234, 235

\section{E}

eborina (Zonitoschema) ........... 275, 276

elegantula (Cantharis) ............... 258, 266

Eletica ....................................... 244

enona (Cantharis) .................... 258, 266

Epicauta................................... 255

exclamationis (Ceroctis) ............ 210, 219

erythroptera (Iselma) .................... 284

extrema (Ceroctis)..................... 210, 218

\section{F}

fahræi (Zonitodema) ............... 285, 286

flavicornis (Mylabris) ............... 180, 193 
flavipennis (Iselma)

PAGE

fulvicornis (Cantharis) 278,280

\section{G}

gamicola (Mylabris) 206

gariepina (Ceroctis) ................ 208, 212

groendali (Ceroctis) ................. 210, 217

guttata (Actenodia) ......................... 240

gyllenhali (Ceroctis)

209,214

\section{$\mathrm{H}$}

hæmacta (Mylabris) 180,190

hilaris (Mylabris)

182,198

hirsuta (Iselma)

278,280

histrio (Decatoma)

223,233

holoserica (Mylabris)

198

HorIINI ..................................... 173

hottentota (Decatoma) ................... 225

hottentota (Mylabris) ............... 178, 187

hottentota (Synhoria) …................. 175

hottentotus (Meloë) ..................... 173

hybrida (Mylabris) ….............. 179, 188

\section{I}

insolita (Decatoma) ................ 223, 231 intermedia (Nemognatha) ......... 288, 289 irritans (Mylabris).................... 181, 195 Iselma

\section{$\mathrm{J}$}

johannis (Decatoma)................. 222, 227

jucunda (Actenodia) ........................ 240

jucunda (Cantharis) ................. 257, 260

$\mathrm{K}$

kakamas (Mylabris) ................. 178, 185

karroensis (Ceroctis)................ 208, 212

korana (Ceroctis) ..................... 208, 211

koranella (Ceroctis) .................. 208, 211

\section{I}

lacerata (Mylabris) ................. 184, 204

lanuginosa (Coryna) ..................... 238

lavateræ (Mylabris) .................. 180, 191

lorigera (Psalydolytta) .................... 254

lucida (Cantharis) ................... 259, 268

lugens (Coryna) ...................... 234, 237

lugubris (Cantharis) ...................... 260

lunata (Decatoma)..................... 221, 225

luteosignata (Eletica) ….......... 246, 248

lydenburgia (Decatoma) ............ 222, 227

Lytta .................................... 255

M

maculicollis (Mimesthes) ................. 220

makalanga (Mylabris) ............... 181, 196

marshalli (Ceroctis) .................. 209, 213

matabele (Mylabris) ................... 183, 199

mashuna (Cantharis) .............. 258, 265

matabelena (Coryna) .................. 234, 236

matoppoena (Mylabris) …....... 182, 197

Meloë ......................................... 170

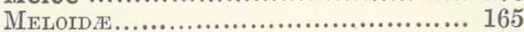

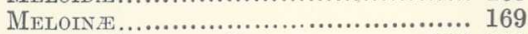

meraca (Nemognatha) .............. 288, 289

meridianus (Meloë) ....................... 172

mesembryanthemi (Cantharis) ... 258, 264

metallescens (Iselma) ............... 279, 282

Mimesthes................................. 220

mima (Cantharis) ..................... 257, 263

minuta (Decatoma) ................. 223, 232

mixta (Coryna) .............................. 235

moerens (Eletica) .................... 245, 247

moesta (Cantharis) ................. 257, 260

mosambica (Ceroctis)........................ 213

mutillata (Cantharis) .................... 261

MylabRini …......................... 173, 176

Mylabris …........................ 176

myops (Mylabris) ....................... 179, 187

mylabroides (Coryna) .............. 235, 238

\section{$\mathrm{N}$}

namaqua (Decatoma) ............. 223, 232

namaqua (Iselma) ...................... 278, 281

namaqua (Mylabris) ....................... 191

nativa (Mylabris) ........................... 207

Nemognatha ......................... 272, 288

nigriceps (Eletica)................. 245, 247

nigricornis (Decatoma) ...................... 232

nitidula (Cantharis) ................ 259, 269

notaticollis (Cantharis).................... 262

notaticollis (Sitaris) ...................... 271

\section{O}

ochroptera (Mylabris) ................... 202 oculata (Mylabris)....................... 178, 184 oculata (Mylabris) ..................... 190, 191 okiepina (Iselma) ................... 279, 282 omega (Decatoma)...................... 221, 225

optata (Cantharis) .................... 257, 262

optata (Iselma) ........................ 279, 282

ovampoa (Cantharis)................ 257, 259

\section{$\mathrm{P}$}

palliata (Mylabris) ................... 180, 193

pallidipennis (Cantharis) ............. 259, 268

pallidipennis (Iselma) ............... 279, 284

Paractenodia ............................. 243

parentalis (Zonitodema) ...........-285, 286

parva (Paractenodia)...................... 243

pectoralis (Cyaneolytta) ........... 250, 251

permutans (Mylabris) .............. 180, 192

peringueyi (Ceroctis)................ 209, 213

pertinax (Mylabris) ................ 182, 197

phalerata (Ceroctis) .................. 210, 220

picta (Mylabris) .............................. 202

picteti (Mylabris) ...................... 183, 202

pilosa (Coryna) ...................... 234, 235

plagiata (Mylabris) .................. 180, 190

planidorsis (Iselma) ................ 279, 284

posthuma (Coryna) ......................... 235

posticalis (Eletica) ....................... 245 
PAGE posticalis (Zonitoschema).......... 275, 277 Prionotolytta ............................ 249 proxima (Zonitodema) ............... 285, 287 pruinosa (Mylabris) ................ 183, 200 Psalydolytta............................. 254 pulchella (Zonitoschema)............ 275, 276 pustulata (Mylabris) ..................... 191

\section{Q}

quadrifasciata (Ceroctis) .......... 210, 218 quadriguttata (Decatoma) ......... 223, 232 quadriguttata (Decatoma) ............. 232

\section{R}

rhodesiana (Decatoma) rhodesiana (Synhoria) rubripennis (Iselma).... ruficeps (Zonitodema) ruficrus (Ceroctis) ......................... 219 rufifrons (Cantharis)............... 257, 260 rufipennis (Iselma) ................ 278, 280 rufonigra (Actenodia) .................. 240

\section{S}

saga (Zonitoschema)

275,276

salisburiana (Decatoma) ........... 222, 226

scalaris (Mylabris).................. 179, 189

sedecimguttata (Mylabris) ......... 183, 201

sellata (Zonitodema)..................... 273

semilineata (Cantharis) .......... 259, 269

serricornis (Ceroctis)................. 209, 215

signifrons (Cyaneolytta) .......... 250, 253

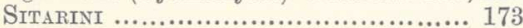

Sitaris..................................... 270

sobrina (Decatoma) ............... 222, 228

spilotella (Cantharis) .............. 258, 265

spuria (Ceroctis)..................... 209, 216

stali (Mylabris) ................... 180, 193

stellenboschiana (Decatoma) ..... 222, 229

strangulata (Cantharis).............. 257, 263

suaveola (Zonitoschema) .................. 275

subrugulosa (Cyaneolytta) ......... 250, 252

subcoriacea (Cyaneolytta)........... 250, 252

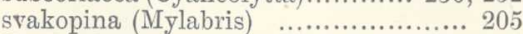

Synhoria
$\mathrm{T}$

tincta (Mylabris) $\ldots \ldots \ldots \ldots \ldots \ldots \ldots . . .182,199$

testudo (Mylabris) ................... 180, 191

tettensis (Mylabris) ................ 179, 189

thunbergi (Mylabris) ..................... 190

tortuosa (Mylabris) ..................... 204

transgressor (Zonitodema) ........ 273, 274

transitoria (Mylabris) .............. 178, 185

transvaalica (Decatoma) .......... 222, 228

transversalis (Mylabris) .................. 187

tricolor (Mylabris) .................... 178, 186

trifolia (Mylabris) ....................... 205

trifurca (Ceroctis) ${ }^{\prime}$..................... 210, 219

tripartita (Mylabris) ............... 181, 196

tripunctata (Mylabris) ............. 181, 194

tristigma (Mylabris) ............... 180, 192

$\mathrm{U}$

umtalina (Decatoma) .............. 222, 226

undata (Decatoma) ................ 222, 229

undatobifasciata (Decatoma) ............ 229

ursus (Iselma) ...................... 278, 279

V

variabilis (Ceroctis) ..................... 214

velata (Cantharis) ................. 257, 261

versuta (Mylabris)................... 179, 188

verticalis (Eletica) ........................ 246

vexator (Ceroctis) ........................ 216

vibex (Mylabris)...................... 181, 195

vicaria (Mylabris) .................. 178, 186

villosa (Mylabris) ....................... 182

villosa (Actenodia) ..................... 243

viridipennis (Zonitodemá) ......... 285, 286

vulgaris (Mylabris) .............. 178, 185

IW

wahlbergi (Eletica) ............... 245, 246

vahlbergi (Actenodia) ................... 241

wahlbergi (Coryna) ........................ 237

Z

zigzaga (Mylabris)................... 184, 203

Zonitodema ....................... 272, 284

Zonitomorpha .......................... 272

ZoNITINI ............................. 173, 272

Zonitoschema .................... 272, 274

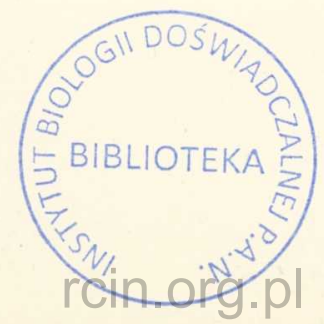


Plate XXII.

\author{
FIG. Mylabris oculata. \\ 2. Horia hottentota 8 . \\ 3. Meloë angulatus. \\ 4. Meloë hottentotus 8 . \\ 5. Eletica cardinalis o . \\ 6. Cantharis nitidula. \\ 7. Zonitomorpha sellata. \\ 8. Zonitoschema suaveola. \\ 9. Sitaris notaticollis. \\ 10. Zonitodema viridipennis. \\ 11. Iselma brunneipes. \\ 12. Nemognatha capensis. \\ 13. Cyaneolytta pectoralis. \\ 14. Cantharis pallidipennis.
}




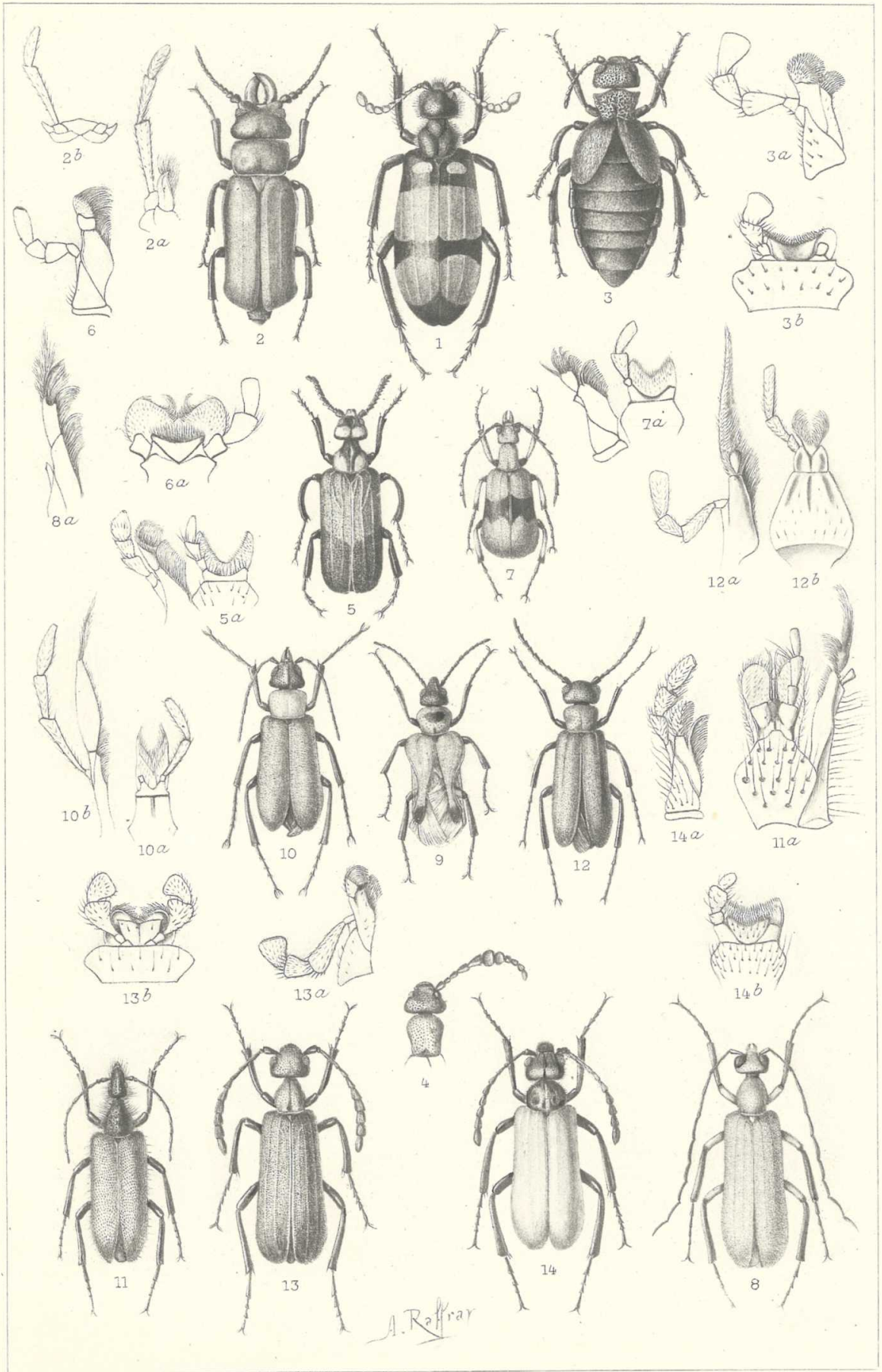




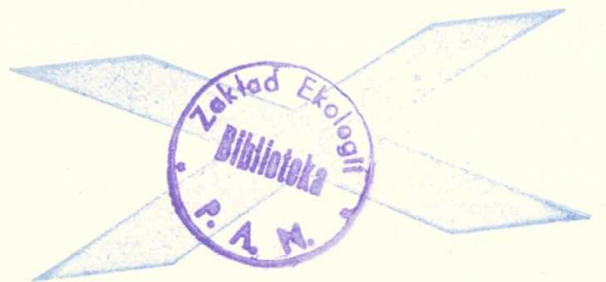

rcin.org.pl 
rcin.org.pl 
Plate XXIII.

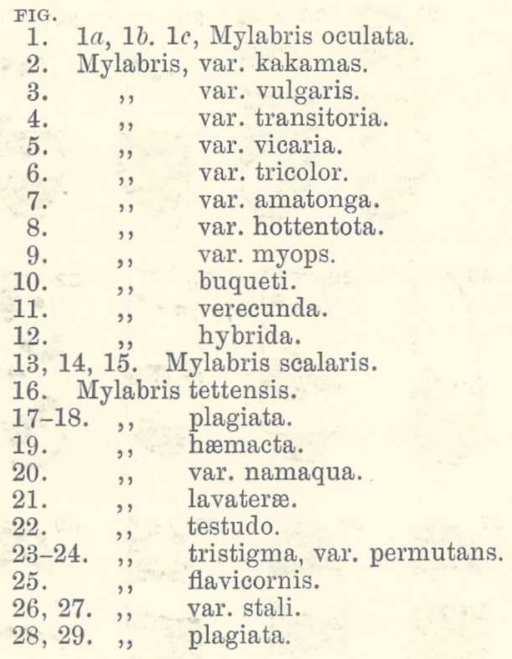

FIG.

30, 31. Mylabris tripunetata.

32. Mylabris connexa.

$33 . \quad$, alterna.

34, 35, 36. Mylabris, var. irritans.

37. Mylabris vibex.

38. , dicincta.

39. ,, tripartita.

40, 41. ,, var. makalanga.

42, 43, 44. Mylabris matoppoena.

45, 46. Mylabris hilaris.

47. Mylabris pertinax.

48. , villosa.

49. ", bicincta.

$50 . \quad$ tincta.

51, 61. ,, matabele.

52. ,, derosa.

53 , ,, pruinosa.

54,55. ,, burmeisteri.

$56 . \quad, \quad$ gamicola.

57. , , sedecimguttata.

58, 59. ,, picteti.

60 . , , trifolia. 


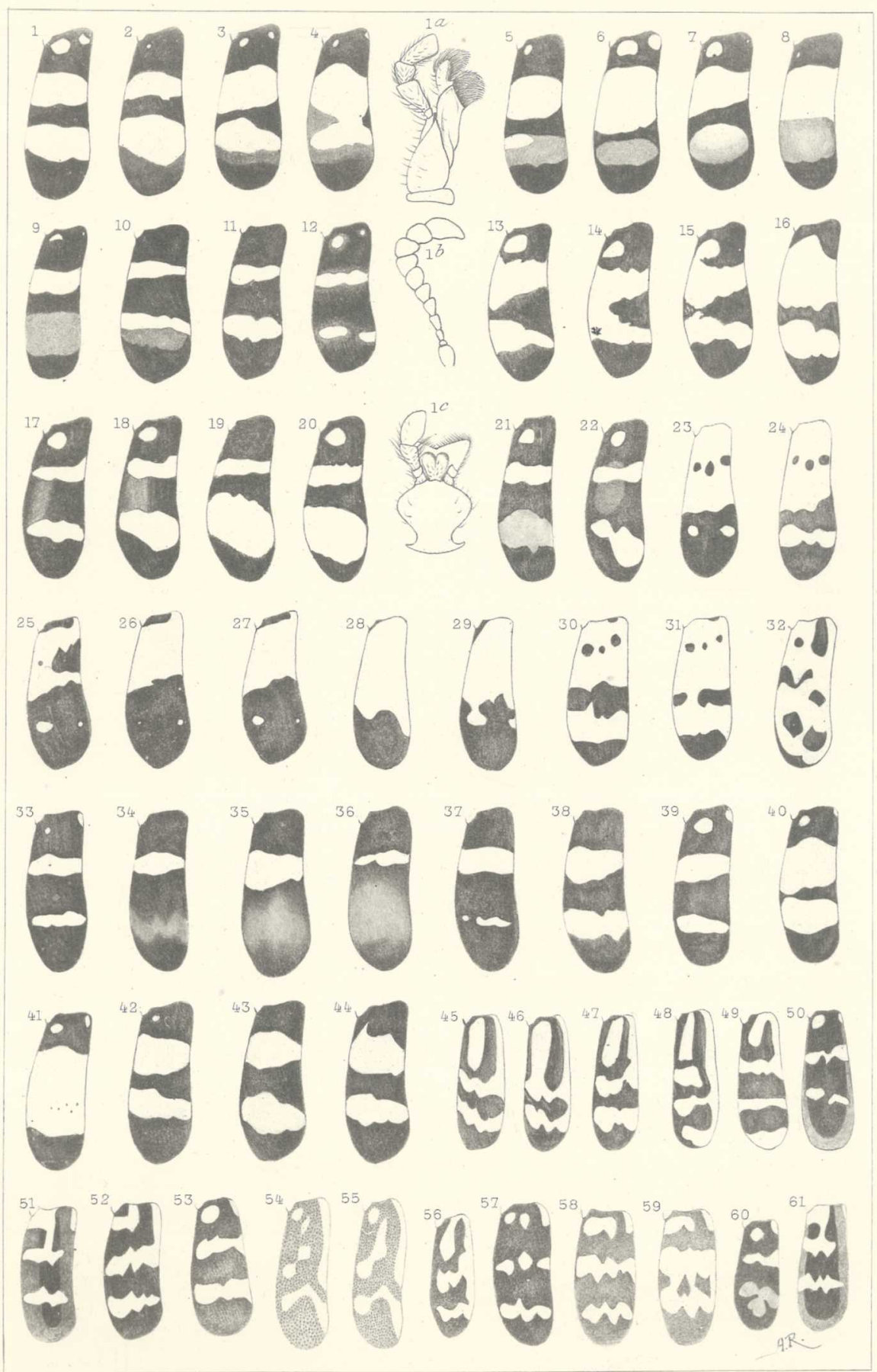




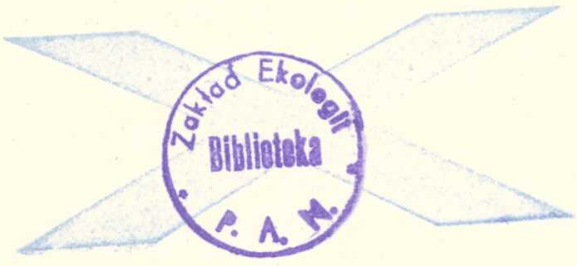

rcin.org.pl 
rcin.org.pl 


\section{Plate XXIV.}

6IG. Mylabris cœeca.

63., zigzaga.

$64 . \quad$ dentata.

65. " ", basibicincta.

66. ,, svakopina.

67. Ceroctis (antenna).

68. ,, capensis.

69. , korana.

70,71. ," koranella.

72. , karroensis.

73. ,, gariepina.

74. , peringueyi.

75. , marshalli.

$76 . \quad$, blanda.

77, 78. ,, gyllenhali.

79 . , serricornis.

$80 . \quad$ spuria.

81, 82, 83. Ceroctis aliena.

84. Ceroctis bohemani.

85. ,, groendali.

86. ,, extrema.

87., quadrifasciata.

88. ,, ruficrus.

89. ,, exclamationis.

90. ,, phalerata.

91. Decatoma (antenna).

92. ,, catenata.

93. ,, caffra.

94. ," hottentota.

95. , lunata.

96. ", var. omega.

97. ,, var. umtalina.

98. ," var. disputabilis.

99. , var. salisburiana.
FIG.

100. Decatoma, var. digressa.

101. ," var. rhodesiana.

102. ,, lydenburgiana.

103. ,, var. johannis.

104. ,, sobrina.

105., transvaalica,

106. ,, undata.

107. stellenboschiana.

108. ,, contorta.

109, 110. ,, africana.

111. ,, insolita.

112. ", quadriguttata.

113. ,, var. minuta.

114. ", namaqua.

115. ,, adamantina.

116, 117. ,, histrio.

118. Coryna (antenna).

119. ,, pilosa.

120. , apicepustulata.

121. ,, apicalis.

122. ,, var. matabelena.

123. ,, lugens.

124. ,, elegans.

125. Actenodia (antenna).

126. ", decemguttata.

127. , curtula.

128. ,, wahlbergi.

129. ,, suffusa.

130. ,, jucunda.

131. , boschimana.

132. Paractenodia parva.

133. Mimesthes (antenna).

134, 135, 136. Mimesthes maculicollis. 


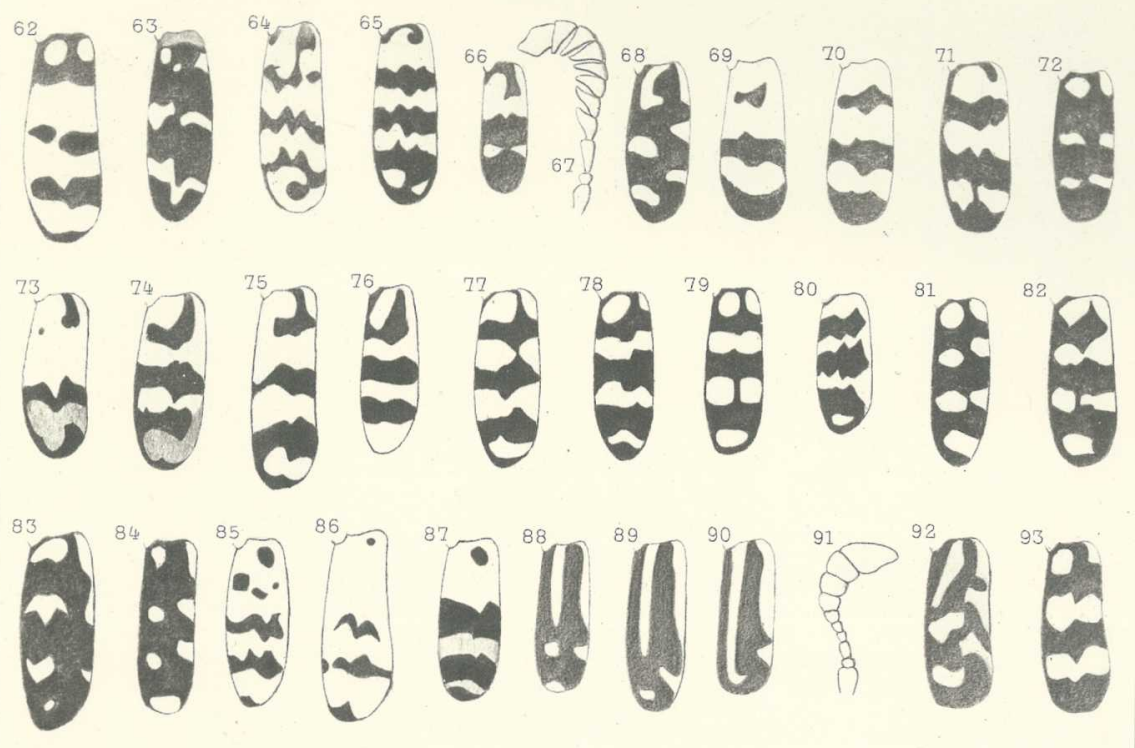

$+250$

a

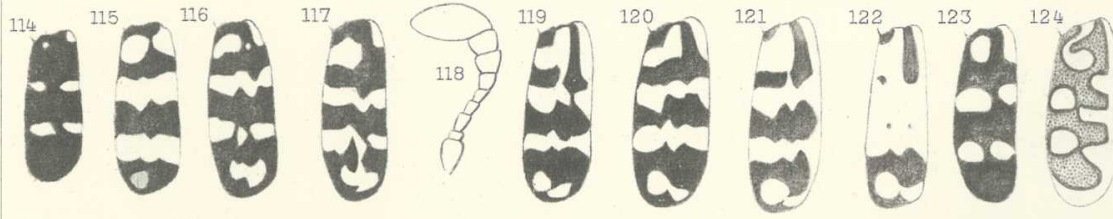

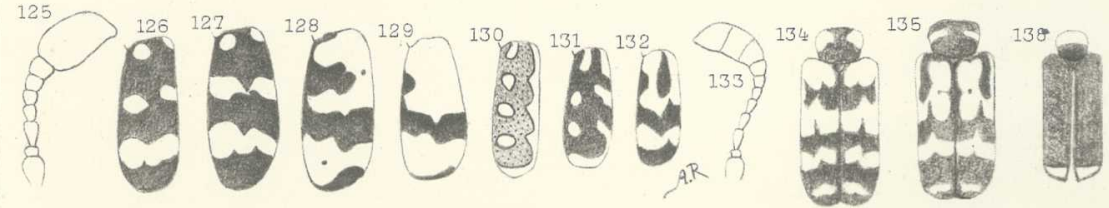




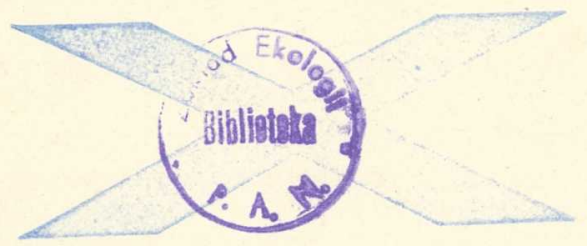

rcin.org.pl 

